\title{
Beethoven's Other Humanism
}

\author{
Daniel K. L. Chua
}

The eye is the lamp to the body. If your eyes are good, you whole body will be full of light. But if your eyes are bad, your whole body will be full of darkness. If the light within you is darkness, how great is that darkness!

-Matthew 6:22-23 (New International Version)

\section{CCT umanity and demythologization" (Humanität und Entmytho- logisierung): ${ }^{1}$ According to Theodor W. Adorno, the power of Beethoven's music is founded on these twin tenets of Enlighten-} ment thought. This idiosyncratic claim is designed to align the composer's profile with that of the modern subject, for "humanity and demythologization" could be construed as the driving forces of the Enlightenment itself. The human who "dares to know" (Sapere aude!), as Kant famously defines the motto of the Aufklärung, is an agent who demythologizes. ${ }^{2}$ The "dare" of this knowing is in breaking every mythical taboo under the banner of reason, turning a being who was once mastered by myth into a subject that masters itself. Demythologization is therefore the mechanism of Enlightenment freedom and, as such, forms the very definition of what it means to be human in the modern world. For Adorno, Beethoven's humanity issues precisely from such a definition: by emancipating music from the cultic functions of the

I am very grateful to Alan Torrance, Jeremy Begbie, and the late Colin E. Gunton for their advice and encouragement for this project, and to Stephen Hinton, Martin Scherzinger, Michael Spitzer, and the anonymous readers for this Journal for their insightful comments.

1. Theodor W. Adorno, Beethoven: The Philosophy of Music, ed. Rolf Tiedemann, trans. Edmund Jephcott (Cambridge: Polity Press, 1998), 142. This phrase from Adorno's essay "The Alienated Magnum Opus: On the Missa solemnis" is also used by Tiedemann as the heading for the final chapter of Adorno's unfinished Beethoven fragments, 162-77.

2. Immanuel Kant, "An Answer to the Question: What is Enlightenment?" in Perpetual Peace and Other Essays on Politics, History, and Morals, trans. Ted Humphrey (Indianapolis: Hackett, 1983), 41. It is worth quoting the beginning of this essay in full, for its ideas inform Adorno's understanding of middle-period Beethoven: "Enlightenment is man's emergence from his self-imposed immaturity [Unmündigkeit commonly translated as "tutelage"]. Immaturity is the inability to use one's understanding without guidance from another. This immaturity is selfimposed when its cause lies not in lack of understanding, but in lack of resolve and courage to use it without guidance from another. Sapere aude! ["Dare to know" or "Dare to be wise"] 'Have courage to use your own understanding!" - that is the motto of enlightenment."

Journal of the American Musicological Society, Vol. 62, Number 3, pp. 571-645 ISSN 0003-0139, electronic ISSN 1547-3848. (C) 2009 by the American Musicological Society. All rights reserved. Please direct all requests for permission to photocopy or reproduce article content through the University of California Press's Rights and Permissions website, www.ucpressjournals.com/reprintInfo.asp. DOI: 10.1525/jams.2009.62.3.571. 
past, the composer mirrors the human who "dares to know." Demythologization is the process that brings the autonomous subject and an autonomous music into recognition as brothers of a new humanity.

But ironically, music's liberation from cult coincides historically with its elevation to the status of cult. Far from secularizing music, demythologization tends to convert the means into an end, turning a religious art into an art religion. This dialectical reversal is not so much a failure intrinsic to music as a condition of the Enlightenment itself. As Adorno points out: "Enlightenment reverts to mythology." 3 This is because the human, in becoming his own master, is no longer made in the image of God but has become a god, creating his own truths as it demythologizes the past. In theological terms, God is "displaced" by man. ${ }^{4}$ Similarly, Beethoven's music "displaces" rather than escapes its cultic functions: the music acts as the liturgy of secular humanism, performing the sacrilegious rites of the Enlightenment. What is secular therefore calls upon the sacred to underwrite its power, and it is precisely this paradox that Adorno perceives in Beethoven's demythologizing authority. His "powers of subjective production," writes the philosopher, are "heightened to the point of hubris, to the point where man becomes Creator." 5 His music, by "gaining-power-over-[it]self," is free to resist myth, "to stand firm against fate," and to hold out "hope without the lie of religion." It is "the thiswordly prayer of the bourgeois class, the rhetorical music of the secularization of the Christian liturgy." It prays: "Thy will be done," except that the will it beseeches is not that of God, but the spirit of man, charged with the task of making the world as it "should be."

Despite its idiosyncrasies, Adorno's claim is merely an intellectual rehearsal of a cliché that has shaped the reception of the composer's music since the nineteenth century; the Beethoven of "humanity and demythologization" is none other than the Promethean Beethoven. ${ }^{8}$ What is human in the composer is modeled on a mythic figure, whose Enlightenment credentials stem

3. Theodor W. Adorno and Max Horkheimer, Dialectic of Enlightenment, trans. John Cumming (London: Verso, 1999), xvi.

4. On the theology of displacement see Colin E. Gunton, The One, the Three and the Many: God, Creation and the Culture of Modernity (Cambridge: Cambridge University Press, 1993), 1-40.

5. Adorno, Beethoven, 151.

6. Ibid., 169 and 174 .

7. Ibid., 163.

8. Kaspar Clemens Zumbusch's Beethoven Monument (1880) in Beethovenplatz, Vienna, associates the composer with Prometheus by placing the bound titan, languishing under the vulture's attack, at Beethoven's feet. See Alessandra Comini, The Changing Image of Beethoven: A Study in Mythmaking (New York: Rizzoli, 1987), 352 and fig. 143. For Comini, Zumbusch's monument represents "a milestone in [the Beethoven] mythology. . . Beethoven had become a citizen-hero: he was both bourgeois and Promethean. He belonged to humanity but came from and had returned to heaven" (386). On the history of Beethoven's Promethean scowl, see idem, "The Visual Beethoven: Whence, Why and Whither the Scowl?" in Beethoven and His World, ed. Scott Burnham and Michael P. Steinberg, 286-312 (Princeton, NJ: Princeton University Press, 2000). 
from his rebellion against the divine order; Prometheus "dares to know" by stealing fire from Zeus in order to liberate mankind from tyranny. He is the myth of demythologization itself, the very symbol of the new humanity for many Enlightenment thinkers. ${ }^{9}$ As the theologian Jürgen Moltmann writes, Prometheus is "the great saint of the modern age." 10 Adorno's inability to outmaneuver this legacy points to the long shadow of Prometheus that Beethoven scholarship has yet to outrun in the twenty-first century. If anything, recent studies have tacitly embraced this figure by updating his name from "Beethoven Prometheus" to "Beethoven Hero." "In Indeed, not only is Prometheus alive today under his alias, he has been formally installed as a scholarly fixture. The last three decades have witnessed the institution of what was always a latent prejudice in the literature on the middle-period works: the "heroic" has escalated from a piece (the Eroica Symphony) to a "phase" and has now become a "period" replete with two distinct styles- "Heroic Style I" and "Heroic Style II."12 So the bias expressed in Adorno's claim that "the first movement of the Eroica ... is really the Beethovenian piece" has now been made official: ${ }^{13}$ the heroic is Beethoven's middle name.

9. David E. Wellbery, for example, reads Goethe's Prometheus (1775) as an act of speech that "realizes the emancipatory program of Enlightenment," freeing man from his delusions through a critique of religious orthodoxy; see Wellbery, The Specular Moment: Goethe's Early Lyric and the Beginnings of Romanticism (Stanford, CA: Stanford University Press, 1996), 287-345, quote taken from 293. The Promethean image gathered momentum in the early nineteenth century as a figure of defiance, endurance, and humanity, evident, for example, in Percy Bysshe Shelley's Prometheus Unbound (1820) and Lord Byron's Prometheus (1816). Thus it is apt that Beethoven's Eroica Symphony should allude to the Prometheus myth. However, there is an irony to this allusion; although Beethoven refers to the titan by quoting his own composition Die Geschöpfe des Prometheus [The Creatures of Prometheus] in the finale, it is the first movement that is associated with the demythologizing character of Prometheus and not the last. In fact, the scenario of the ballet Die Geschöpfe des Prometheus, which was choreographed for the Imperial Court, does not cast the rebel in the glory and gore of the French Revolution, but as a rather refined figure of the German Aufklärung, instructing his creatures in the arts and sciences to the strains of an English country dance. On the relation between the ballet and the symphony see Constantin Floros, Beethovens Eroica und Prometheus-Musik (Wilhemshaven: Heinrichshofen, 1978); and Thomas Sipe, Beethoven: Eroica Symphony (Cambridge: Cambridge University Press, 1998), 11-16 and $117-18$.

10. Jürgen Moltmann, Theology of Hope: On the Ground and the Implications of a Christian Eschatology, trans. James W. Leitch (Minneapolis: Fortress Press, 1993), 24.

11. See Scott Burnham, Beethoven Hero (Princeton, NJ: Princeton University Press, 1995).

12. Lewis Lockwood summarizes this scholarly escalation in "Beethoven, Florestan, and the Varieties of Heroism," in Beethoven and His World, ed. Scott Burnham and Michael P. Steinberg (Princeton, NJ: Princeton University Press), 36-41. Alan Tyson in "Beethoven's Heroic Phase," Musical Times, 110, no. 1512 (1969): 139-41, coined the term "Heroic Phase" to cover the period 1801-4; Maynard Solomon in Beethoven (London: Cassell, 1977), 163-72 and 187-206, uses "Heroic Period" to designate the years 1803-12; William Kinderman in Beethoven (Oxford: Oxford University Press, 1995), 86-138, divides the period 1803-9 into "Heroic Style I" and "Heroic Style II." There are two recent monographs devoted to the heroic Beethoven, Burnham's Beethoven Hero, and Michael Broyles's The Emergence and Evolution of Beethoven's Heroic Style (New York: Excelsior, 1987).

13. Adorno, Beethoven, 66. 
Even those who resist the name fall under its spell. Lewis Lockwood, in an attempt to ground this escalating concept, has limited the meaning of "the heroic" either to works by Beethoven that contain the word "hero" in the title (of which there are only two $)^{14}$ or to those that portray heroes, such as Egmont and Coriolanus. From this narrow selection of pieces, Lockwood splits Beethoven's heroic identity into three character types:

1. the visionary hero who triumphs by the force of will

2. the stoical hero who resists tyranny through endurance, and

3. the fallen hero whose fame is monumentalized in death. ${ }^{15}$

But far from dispelling the Promethean image, these types can be seen to represent one hero exhibiting the same defiance under three different circumstances: the will to conquer is celebrated in victory, potent in adversity, and unquenchable in death. They merely underline the Enlightenment spirit that defies every prohibition in its progress toward truth. ${ }^{16}$ So Lockwood's attempt to bind the hero ultimately leaves Prometheus unbound. His overly literal endeavor to limit the heroic fails because it misses the Promethean strategy of these works: like the new humanity of the Enlightenment, the demythologizing hubris of the music results in its own mythologization. As Wagner says concerning the Eroica, Beethoven's music is not about $a$ hero; it is heroism itself. ${ }^{17}$ The escalation of the concept from the particular to the universal is built into the music. The heroic wants to expand from a single piece to an entire period. It is a self-canonizing move that guarantees the persistence of the music by inscribing the hero's resilience in the work. Or, to put it another way, the hero functions as the "extra-musical" program that sustains the immortality of Beethoven's "absolute" music. ${ }^{18}$

But this immortality is not only programmed into the works. According to Scott Burnham, Beethoven's music persists because the heroic is also programmed into us; the new humanity it proclaims endures as the "moral force" of our current humanity, as if we were still heirs of the Enlightenment. So it is

14. Namely, the Eroica Symphony and the slow movement of the Piano Sonata in E-flat Major, Op. 26, "Marcia funebre sulla morte d'un eroe" ("Funeral march for the death of a hero").

15. Lockwood, "Beethoven, Florestan, and the Varieties of Heroism," 43.

16. In fact, far from containing the hero, Lockwood's categories have the effect of illuminating the extension of the heroic element beyond the middle period, for the "resignation" associated with the late works is merely another name for the stoical endurance of the hero. Thus the late period not only contains remnants of the heroic style in, say, the Promethean struggle of the Hammerklavier or the triumphant brotherhood of the Ninth Symphony, but is itself heroic in its acceptance of suffering. "Beethoven hero" turns out to be the master trope of the composer's reception from the middle to the late period.

17. See Burnham, Beethoven Hero, xv.

18. See Daniel K. L. Chua, Absolute Music and the Construction of Meaning (Cambridge: Cambridge University Press, 1999), 149-66. I am using "absolute" here as shorthand for a far more complex and fluid concept that emerged at the turn of the nineteenth century to designate a "pure" form of instrumental music. 
not aesthetics, claims Burnham, but ethics that ensures the continuing significance of the heroic paradigm. ${ }^{19}$ And as with Adorno, the moral power of the music resides in its secularization of the Christian liturgy. This power, for Burnham, is Eucharistic: those who partake of Beethoven's music experience the real "presence" of a humanity that originated in what he calls the Goethezeit, an age in which the self became the center and creation of knowledge. ${ }^{20}$ The particular context in the revolutionary ego of German philosophy may no longer be relevant, suggests Burnham, but the music, as an act of remembrance, makes present a defining moment of humanity which we have not yet outlived: Beethoven sounds out the Promethean spirit in us. ${ }^{21}$ As Burnham writes: "Within the context of the Goethezeit, and, by extension, of the entire modern era, the presence within the heroic style amounts to a theophany in the Age of Self." 22 Beethoven makes real the simultaneous act of demythologization and remythologization that is our humanity. The fact that we still call on the heroic Beethoven to mark the endurance of the human spirit, from the fall of the Berlin Wall to the atrocities of $9 / 11,{ }^{23}$ is testimony to its living presence. So Adorno is not alone: "humanity and demythologization" are still the twin tenets of faith for those who believe in Beethoven today.

If Beethoven's Promethean defiance can tear down the walls of tyranny in Berlin, if its twin tenets can rebuild the twin towers of New York, then it is likely that its ethics will continue to speak for the epochal events of the future. The hero will survive as he is programmed to do so. The question is whether this demythologizing hero is an adequate definition of humanity and its ethical task in the twenty-first century. "Must we always call upon Beethoven to attest to [the morality of the human endeavor]?” writes Esteban Buch. ${ }^{24}$ After

19. See Burnham, Beethoven Hero, 148 and 151.

20. As Brian Hyer notes in his review of Beethoven Hero in Music Theory Spectrum 20 (1998): 135 , the unacknowledged "presence" behind the book is probably George Steiner's Real Presences (Chicago: University of Chicago Press, 1989).

21. Although Burnham draws on German transcendental philosophy to construct Beethoven's heroic self, the political and biographical contexts also conspire to shore up the composer's Promethean image; the ideals of the French Revolution, the Messianic figure of Napoleon, and the ailing Beethoven "seiz[ing] fate by the throat," are as much models for the heroic style as Kant's transcendental subject, Fichte's self-positing ego, or Hegel's absolute $I$. Different commentators simply select different plots to contextualize the same figure: Burnham's philosophical account, Adorno's political reading, and Solomon or Lockwood's biographical explanations, for example, merely reenforce one another to justify Beethoven's Promethean spirit.

22. Burnham, Beethoven Hero, 150.

23. To celebrate the fall of the Berlin Wall in November 1989, Leonard Bernstein conducted the Ninth Symphony on both sides of what was formerly a divided city. Notably, the word "Freude" was replaced by "Freiheit." Twelve years later, on what would have been the anniversary of Adorno's ninety-eighth birthday, the twin towers of the World Trade Center in New York collapsed in an act of terror. In London, the last night of the Proms had to be hastily reprogrammed; once again, the finale of Beethoven's Ninth Symphony was wheeled out to galvanize the human spirit to press forward "joyfully on his way to triumph" like the hero of Schiller's text.

24. Esteban Buch, Beethoven's Ninth: A Political History, trans. Richard Miller (Chicago: University of Chicago Press, 2003), 267. 
all, the failure of the Enlightenment to procure its promises has led to an extensive critique of this heroic subject and its Promethean spirit, not least by Adorno himself. The prayer "Thy will be done" did not bring heaven on earth for Adorno but the reality of hell in which "Auschwitz" is merely "a metonym" for human society. ${ }^{25}$ That Beethoven and Auschwitz should coexist in the same breath is, of course, an outrage; 26 that it is thinkable, however, indicates how high the ethical stakes are. No other composer can fall from such a height because no other composer has had so much invested in the ethics of "humanity and demythologization."

So is it worth keeping faith with this Beethoven? If, under critique, his heroic mantle is wearing a little thin, exposing the failure of his moral credentials, then may be it is time to ditch the heroic image altogether. After all, "humanity and demythologization" is not the only definition of the human in Beethoven. The heroic does not necessarily represent the composer; in fact, such a narrow focus may suppress his nonheroic identities. ${ }^{27}$ So would it be possible to uncover another humanism beneath the Promethean mantle-an ethics without heroes?

If Beethoven's Promethean values were merely a matter of the music's moral psychology, then one could follow Lockwood's cue and confine the heroic to a few "characteristic" works. If it were a matter of the music's reception, then the heroic could be relegated to a work's discursive history, leaving the music relatively immune from the hero's moral failures. Adorno's point, however, is that demythologization is not merely a trope in Beethoven; it is what Beethoven does to music. Music's very emancipation is a result of demythologization and is therefore a testament to the new humanity. The ethics is the music itself. The moral psychology of the Eroica Symphony may drama-

25. J. M. Bernstein, Adorno: Disenchantment and Ethics (Cambridge: Cambridge University Press, 2001), 373 .

26. The correlation between the human and inhuman in Beethoven is not an idiosyncratic twitch in Adorno's dialectics. The relation, for example, is explicit in Anthony Burgess's $A$ Clockwork Orange. The most recent, if somewhat banal, variation on this theme occurs in Peter Segal's film Get Smart in which the villain, Siegfried (Terence Stamp), plants a bomb in the Walt Disney Concert Hall to be triggered by the sound of the Ninth's final chords. Violent readings of the Ninth Symphony go back as far as Nietzsche's Birth of Tragedy, where the mixture of Dionysian revelry and Schopenhauerian philosophy masks a horrific ritual of individual annihilation. Curiously, Nietzsche may not have been too far from one of Beethoven's conceptions of the work: in an early idea for the Ninth Symphony, the composer described the last movement as "a festival of Bacchus." In this light, freedom and joy take on a more violent and debauched connotation. See Friedrich Nietzsche, "The Birth of Tragedy" and "The Case of Wagner," trans. Walter Kaufmann (New York: Random House, 1967), 37-38. Beethoven's note concerning his projected symphony (Bonn Beethoven Archiv Bsk 8/56) is quoted by many scholars including Alexander Wheelock Thayer, in Thayer's Life of Beethoven, rev. E. Forbes (Princeton, NJ: Princeton University Press, 1967), 888; and Barry Cooper, in Beethoven (Oxford: Oxford University Press, 2000), 265.

27. See Nicholas Mathew, "Beethoven and His Others: Criticism, Difference, and the Composer's Many Voices," Beethoven Forum 13 (2006): 148-87. 
tize the ethics, the discourse may disseminate its meaning, but ultimately it is the music's "absolute" status that defines its moral force. ${ }^{28}$ Beethoven's ethics is not merely a topic but a technique. So any reevaluation of Beethoven's humanism will have to start from the inside out, from an ethics inscribed in the very mechanism of the music's self-proclaimed autonomy. After all, the Promethean hero is not defined by his external acts but by an inner strength that pits itself against a prevailing order. Heroic autonomy is a violent, monadic force. And it is only in the analysis of this internal pressure that one can gauge the ethics of "humanity and demythologization" that lies behind a work's monadic identity.

\section{The Formal Law of Freedom}

Monads, according to Gottfried Leibniz, are irreducible soul-like substances, each divinely programmed as a unique "mirror of the universe." Yet despite this preestablished harmony, monads do not interact; they are ontologically independent from each other. Their glistening surface merely hides a darkness within. Or as Leibniz puts it, monads are "windowless." 29 These objects, shut in autotelically upon themselves, are analogous to musical works for they, too, are "windowless," states Adorno. ${ }^{30}$ Works are blind inasmuchas they are impervious to the outside world. Yet it is this in-sight that constitutes their autonomy; they are oiled from within by what Adorno calls "the formal law of freedom" (das Formgesetz der Freibeit), an internal logic liberated from external obligations. ${ }^{31}$ This "formal law" is music's demythologizing act. In the same way as "Enlightenment," to use Kant's definition, “is man's release from his self-incurred tutelage" through the exercise of reason alone, ${ }^{32}$ so music, through its internal laws, liberates itself from its subservience to the disciplinary functions of church and court. Beethoven, the "revolutionary bourgeoisie,"

28. On such character types, see Richard Will, The Characteristic Symphony in the Age of Haydn and Beethoven (Cambridge: Cambridge University Press, 2002).

29. Gottfried Leibniz, Monadology, in Discourse on Metaphysics, Correspondence with Arnauld, and Monadology, trans. George Montgomery (LaSalle, IL: Open Court Publishing Company, 1993), 263 and 252.

30. In his Introduction to the Sociology of Music, trans. E. B. Ashton (New York: Seabury Press, 1976), 211, Adorno writes: "The relation of works of art to society is comparable to Leibniz's monad. Windowless - that is to say, without being conscious of society, and in any event without being constantly and necessarily accompanied by this consciousness-the works of art, and notably of music which is far removed from concepts, represent society." In this way, explains Adorno elsewhere, "the relationship of the work and the universal becomes the more profound ... the more it becomes infatuated with its own detached world, its material, its problems, its consistency, its way of expression. Only by reaching the acme of genuine individualization ... does the work become truly the bearer of the universal." Adorno, "Theses Upon Art and Religion Today," in Notes to Literature, 2 vols. (New York: Columbia University Press, 1991-92), 2:297.

31. Adorno, Beethoven, 42.

32. Kant, "An Answer to the Question: What is Enlightenment?" 41. 
claims Adorno, represents "the prototype of a music that has escaped from its social tutelage and is esthetically fully autonomous[.] . . In it . . . the essence of society, for which he speaks as the vicar of the total subject, becomes the essence of music itself." 33 Music's monadic blindness turns out to be the living mirror of society.

However, this newly enlightened music is not as free as its "formal law of freedom" may suggest; music's autonomy is merely the discipline of the external world "turned inwards," writes Adorno. The outward order from which music frees itself is reconstituted as an internal law so that its aesthetic selfdetermination is simultaneously "reflected [and] wrenched from its immediate social purpose." 34 The music mirrors the contradiction of a self-positing subject that internalizes the very discipline from which it emancipates itself in order to be human. Being human, therefore, has inhuman consequences. Thus music's "formal law of freedom" is simultaneously its latent law of oppression. The details of this inversion from freedom to oppression can be determined from the very words that form the concept, words that are equally a synecdoche of Beethoven's heroic image as they are of music's monadic autonomy: form, law, freedom.

Form. If, as Adorno claims, the musical monad secularizes the past as an inner discipline, then the ritual its "formal law" internalizes is the sacred violence of purification, a separation that either discards the Other as "unclean" or sets it apart for total destruction. ${ }^{35}$ "The purity of form," claims Adorno, "is modelled on the purity of the subject"; the ego's self-constitution is an ascetic act that achieves it monadic state by "divesting itself of the nonidentical."36 Similarly, music's "formal law of freedom" is purely formal because it preens itself of foreign bodies, expelling everything that cannot be integrated into its structure. After all, "without rejection there is no form," states Adorno. ${ }^{37}$ And since form is the locus of music's newly discovered autonomy, such music is necessarily inhumane in its pursuit of freedom. Indeed, "the purer the form and the higher the autonomy of the works," writes Adorno, "the more cruel they are." 38

33. See Adorno, Introduction to the Sociology of Music, 209-10, repr. in Beethoven, 43; translation modified.

34. Adorno, Beethoven, 42.

35. As Adorno writes in ibid., 172-73: "The holiness of music is its purity from dominance over nature; but its history is the inevitable development of that dominance as it became master of itself."

36. Theodor W. Adorno, Aesthetic Theory, trans. R. Hullot-Kentor (Minneapolis: University of Minnesota Press, 1997), 162.

37. Ibid., 144.

38. Ibid., 50. Although form, according to Adorno, should follow the "feel" of the material (Formgefübl as opposed to Formgesetz), discovering and molding its singularity, given its Platonic heritage, it is always in danger of imposing its universal purity upon the material it shapes. "Formalistic classicism commits an affront," writes Adorno. "Precisely the beauty that its concept 
Law. Exclusion, then, is the basis of music's formal function; music's legal function-its "formal law"-merely enforces these structural boundaries by policing freedom with a violence that coerces the internal material to obey the form through various types of contractual controls that align form with content. Just as Kantian autonomy is based on a legal subject that exerts its rights over nature through laws created within itself, so music assumes a legislative function, holding time to account with obligations that order the tonal and thematic material. These contractual laws drive an economy that binds the monadic shape into a dense, impenetrable form in which every particular must add up to the totality; harmonic disjunctions must be closed within the system and thematic loose ends tied up in order to resolve any seemingly anomalous event. In so doing, the law appears to justify the form as the result of its internal processes, as if the form had been reproduced out of subjective freedom.

Freedom. However, the freedom of the formal law is not the process of the law per se, as if it were some kind of self-winding mechanism; rather its freedom is found in the giving of the law; or, as Ludwig Tieck puts it, music "prescribes its own laws to itself." 39 In other words, music's inner law is dictated by an outer freedom. In fact, this ability to be simultaneously inside and outside the system is championed by Burnham as the essence of Beethoven's heroic style; the music emanates a "telling presence" that narrates the form as an external agent while enacting its own internal procedures; the deed, which is a consequence of the law within, is directed by the sovereignty of the will without. ${ }^{40}$ So, despite its inner discipline, music, inasmuch as it gives the law to itself, is free because it is outside the internal rule it imposes; this act is not subject to the formal law of exclusion, but is the exception which enables the form to exclude anything that is not for itself. Indeed, this logic of exception, according to the philosopher Giorgio Agamben, is the very structure of sovereignty: ${ }^{4}$

glorifies is sullied by the manipulative, "composed" violence of its exemplary works. All that is imposed and added secretly gives the lie to the harmony that domination undertakes to produce. . . . Reconciliation as an act of violence, aesthetic formalism, and unreconciled life forms a triad" (ibid., 48). On the relationship between form (rationality) and mimesis (nature) see Morton Schoolman, "Toward a Politics of Darkness: Individuality and Its Politics in Adorno's Aesthetics," Political Theory 25 (1997): 63-65. On Beethoven's expurgatory voice, see Mathew, "Beethoven and His Others."

39. Wilhelm Heinrich Wackenroder and Ludwig Tieck, "Symphonien," in Phantasien über die Kunst, für Freunde der Kunst (Hamburg, 1799), in Werke und Briefe von Wilhelm Heinrich Wackenroder (Berlin: Verlag Lambert Schneider, 1938), 254. Wackenroder and Tieck are paraphrasing Kant's definition of genius ("Genius is the talent [natural endowment] which gives the rule to art"), transferring the act of creative legislation to the musical work itself. See Immanuel Kant, Critique of Judgement (1790), trans. James Creed Meredith (Oxford: Clarendon, 1969), 168.

40. Burnham, Beethoven Hero, 144.

41. See Giorgio Agamben, Homo Sacer: Sovereign Power and Bare Life, trans. Daniel HellerRoazen (Stanford, CA: Stanford University Press, 1998). Also see note 267. Agamben's notion of 
music's freedom is therefore modeled on the subject as ruler, giving credence to Adorno's claim that "the autonomy of the art-work has its source in heteronomy, much as the freedom of the subject arose from lordly sovereignty." 42

So in summary, music's "formal law of freedom" hides an inhumane order behind its humanism: its inhumanity can be defined through the three terms that make up the concept:

Form: the purity of exclusion

Law: the necessity of contractual control

Freedom: the external will that ordains an internal order

The "formal law of freedom," then, is an autonomy of pure force, the unimpeded will of a legal subject whose sovereignty is maintained through what it excludes and what it binds in its process of self-formation (Bildung).

\section{The Sublime Monad}

The "formal law of freedom" may constitute the monad's internal forces, but it is its impact on the outside world that displays its ethical effect. According to Kant, form, in contrast to the formlessness of the sublime, ought to be beautiful through the harmonious play of its internal processes; but because music's freedom has taken the form of the law its "outward effect" on Adorno is one of fear- "what Kant called our awe before the sublime."43 The moral law, states Kant, is a force that overwhelms the subject's sensibility with its intimations of the infinite; 44 similarly for Adorno, music's formal law causes the individual to "shudder" before its totalizing processes. ${ }^{45}$ Adorno clearly has Beethoven in mind as the exemplar of the monadic law, focusing in particularly on the heroic Augenblick:46 "When the sublime becomes a totality" he writes, "it is a moment [Augenblick] of transcendence." 47 The Augenblick is a

\footnotetext{
"the state of exception" arises from the work of the political theorist, Carl Schmitt, for whom the state of emergency (the exception) was not so much an extreme example of sovereign rule as its fundamental category; see Schmitt, Political Theology: Four Chapters on the Concept of Sovereignty (1922), trans. George Schwab (Chicago: University of Chicago Press, 2005).

42. Adorno, Beethoven, 42.

43. Ibid.

44. In particular, Kant draws attention to the sublimity of the second commandment concerning the ban on making graven images: like the monad, the sublime law is blind in that its power cannot be represented. See Kant, Critique of Judgement, 127.

45. Adorno, Aesthetic Theory, 245.

46. See Adorno, Beethoven, 42. In this fragment [107], which has been the basis for my formulations on the "formal law of freedom," Adorno writes: "re. Beethoven?-but in general, of the utmost importance." As is commonly the case, Beethoven's heroic works function as the paradigm for music in general.
}

47. Ibid., 42. 
moment of form for Adorno, a revelation of the totalizing force that binds the particulars dynamically together as a product of freedom. ${ }^{48}$ So "when the sublime becomes a totality," what is revealed by the music is the law of autonomy itself; the external will that governs the inner forces suddenly transcends the material. As a "sublime totality," this moment is the intersection of fear (the sublime law) and form (the autonomous totality), and so reveals the disciplinary force behind the rule of freedom. The equation between violence and order was already acknowledged as early as 1810 in E. T. A Hoffmann's celebrated review of Beethoven's Fifth Symphony, where the motivic asceticism of the material generates the prolific power of the sublime: ${ }^{49}$ the tighter the internal network the more terrifying the form. ${ }^{50}$ Far from manifesting itself in the incalculable vastness of nature as described by Kant, the sublime in Beethoven's heroic works achieves its effect through an obsession with formal procedures. It is reason posing as absolute power, crushing the individual beneath its logic. Thus Beethoven's "symphonic authority," writes Adorno, always threatens to suck the recipient into its internal processes as a kind of "ritual reception ... within an evolving whole."51

So instead of consuming the hero's real presence as Burnham's Eucharistic encounter celebrates, for Adorno, the individual is swallowed whole by the music. Freedom, then, should be the last concept on the philosopher's lips as he cowers before this voracious totality. But it is precisely this fear of being absorbed that Adorno regards as the "real function" of music's autonomy: the sublime totality engenders a "resistance" within the recipient. ${ }^{52}$ Freedom is not found in the music's formal procedures but in the subject's reaction against them. The Fifth Symphony, for example, leaves Hoffmann in a state of unquenchable yearning for the infinite, as if the sublime were a catalyst for the subject's own becoming. ${ }^{53}$ After all, in Kant's aesthetics, the overpowering negations of the sublime are supposed to awaken a moral power within the

48. On the heroic Augenblick see Daniel K. L. Chua, "The Promise of Nothing: The Dialectic of Freedom in Adorno's Beethoven," Beethoven Forum 12 (2005): 23-24; and Naomi Waltham-Smith, "Adorno's Augenblick and the Ethics of Late Beethoven" (PhD diss., King's College London, 2009).

49. As Agamben points out, the freedom of the sovereign involves the paradoxical union of justice and violence- the "force of law" lies behind the law of freedom; see Agamben, Homo Sacer, 30-38.

50. See E. T. A. Hoffmann, "Review of Beethoven's Fifth Symphony," Allgemeine musikalische Zeitung, 4 and 11 July 1810, cols. 630-42 and 652-59; repr. with some changes (1899), trans. in E. T. A. Hoffmann's Musical Writings: "Kreisleriana," "The Poet and the Composer," Music Criticism, ed. David Charlton, trans. Martyn Clarke (Cambridge: Cambridge University Press, 1989), 234-51. Also see Chua, Absolute Music and the Construction of Meaning, 181-82.

51. Adorno, Beethoven, 119.

52. Ibid., 42 .

53. See Hoffmann, "Review of Beethoven's Fifth Symphony," AMZ, and in E. T. A. Hoffmann's Musical Writings, 238-39; see a related discussion in "Beethoven's Instrumental Music," in E. T. A. Hoffmann's Musical Writings, 98. 
subject. So when Adorno shudders before this music, he, like Hoffmann before him, discovers a moral force inside himself; in resisting its power, the music's "formal law of freedom" strikes revolutionary "sparks from [his] soul," 54 in the same way that the French Revolution, for Kant, is sublime, promising a freedom that is truly human, even if its reality is truly horrifying. ${ }^{55}$ So the musical monad is not only an internal reflection of the subject's autonomy, it actually reinforces it, causing a sublime reaction as the listening subject re-forms itself against the overwhelming presence of the music as a kind of countermonad. In the heroic Augenblick, one becomes human through a confrontation with a monadic force, a struggle that reenacts in the recipient the Promethean image of humanity associated with Beethoven's heroic works. ${ }^{56}$

Being human, it seems, is a reaction, a freedom experienced in relation to the sublime monad. But since the moment of contact is one of mutual aggression, it is questionable whether the relation is truly human(e). After all, monads, because they are "windowless," cannot relate by definition. Or to put it another way: the heroic Augenblick has no eyes; it is oblivious to the outside world. At first, this may appear contradictory. How can an Augenblick be blind? How can its visionary light radiate darkness? But the failure to relate stems precisely from its claim to see, for the Augenblick is equivalent to what the ethical philosopher Emmanuel Lévinas calls an "egology of synthesis"; it is a seeing that accompanies the "I think" of the modern self as it gathers all alterity into a "synchrony of representation." 57 The monadic moment of self-presence is one of total vision, a panoptic glory that shimmers over an impervious surface. This visionary glance, epitomized by the blaze of $\mathrm{C}$ major that ignites the finale of Beethoven's Fifth Symphony, blinds itself by the very light through which it claims to capture the world. Its glory is merely the solipsism of the hero's own reflection, sucking all it sees into the black hole

54. Adorno, Beethoven, 42.

55. See Adorno, Aesthetic Theory, 349; Jean-François Lyotard, "The Sign of History," in Post-Structuralism and the Question of History, ed. Derek Attridge, Geoff Bennington, and Robert Young, 162-80 (Cambridge: Cambridge University Press, 1987); and Christopher Norris, What's Wrong with Postmodernism: Critical Theory and the Ends of Philosophy (Baltimore: Johns Hopkins University Press, 1990), 208-21.

56. For an elaboration of the ethics of a sublime withstanding in Adorno's aesthetics (albeit from a Habermasian perspective), see Albrecht Wellmer "Adorno, Modernity, and the Sublime" in Endgames: The Irreconcilable Nature of Modernity, trans. David Midgley (Cambridge MA: MIT Press, 2000), 155-81. Michael Spitzer in Music as Philosophy: Adorno and Beethoven's Late Style (Bloomington and Indianapolis: Indiana University Press, 2006), 256-80, applies Wellmer's ideas to the late works of Beethoven, which he regards as an expression of the "allegorical sublime." Also see note 63 .

57. Emmanuel Lévinas, "Diachrony and Representation," in Entre nous: On Thinking-of-theOther, trans. Michael B. Smith and Barbara Harshav (New York: Columbia University Press, 1993), 161. The italics in "representation" are added. The essay also appears in idem, Time and the Other, and Other Essays, trans. Richard A. Cohen (Pittsburgh: Duquesne University Press, 1987), 97-120. 
of his totalizing presence. This "mechanism of 'pathic projection,'” writes Adorno, which "determines that those in power perceive as human only their own reflected image, instead of reflecting back the human as precisely what is different" is at the heart of the revolutionary subject. ${ }^{58}$ The "I," as Johann Gottlieb Fichte describes it, knows itself "as an eye which rests on itself and is closed into itself. It sees nothing outside of itself, but it sees itself." 59 Such windowless light, by its very inaccessibility, is the sublime that renders the heroic monad invincible and impenetrable.

And if monads are nonrelational by nature, sublime monads are doubly so. For as the theologian John Milbank argues, the sublime is a nonreciprocal aesthetic: "The sublime explicitly refuses reciprocity. . . Insofar as the invisible sublime arrives in the visible, it loses itself in a merely negative kenosis. Inversely, where the visible offers itself to the invisible [the sublime], this is utter self-sacrifice." 60 The sublime either empties itself of meaning as some ungraspable force under which we shudder or absorbs the Other in its assertion of power. It either blinds the visible or is blind to it. Thus without eyes, the sublime monad is ultimately inhuman for it cannot return the gaze of an Other. Indeed, the sublime, as an aesthetic of fear, finds pleasure precisely in what is nonrelational; it creates division in the face of difference and defiance instead of love, pandering to what many commentators regard as the pathological condition of our existence: "the fear of the Other" (John Zizioulas), or more accurately, "a horror of the Other who remains Other" (Lévinas). ${ }^{61}$ The

58. Theodor W. Adorno, Minima Moralia: Reflections from Damaged Life, trans. E. F. N. Jephcott (London Verso, 2002), 105.

59. J. G. Fichte, Nachgelassene Schriften 1800-1803, part 2 of Gesamtausgabe der Bayerischen Akademie der Wissenschaften, edited by Reinhard Lauth and Hans Jakob (Stuttgart-Bad Cannstatt: Frommann-Holzboog, 1962-), vol. 6 (1983), p. 169; the translation is from Wellbery, The Specular Moment, 60.

60. John Milbank, "Beauty and the Soul," in Milbank, Grahan Ward, and Edith Wyschogood, Theological Perspectives on God and Beauty (Harrisburg PA: Trinity Press International, 2003), 7 .

61. John D. Zizioulas, "Communion and Otherness," Orthodox Peace Fellowship's Occasional Paper No. 19 (Summer, 1994), http://incommunion.org/articles/older-issues/ communion-and-otherness (accessed 16 March 2009); and Emmanuel Lévinas, "La trace de l'autre," in En découvrant l'existence avec Husserl et Heidegger (Paris: Vrin, 1970; 1st ed. 1949), 188. Recent studies have revived the sublime as a way of renewing communication, of which Wellmer's "Adorno, Modernity, and the Sublime" is the most pertinent. To understand the sublime as nonrelational contradicts Wellmer's recasting of modern art as an expression of communication in its sublime "act of withstanding the negativity of the world"; by resisting the abyss of meaninglessness brought on by the collapse of metaphysics, modern art mirrors the fragility of the Habermasian communication model, and so provides "a direct experience of [the subjects'] power to articulate, to communicate, to fashion their world" (172). The sublime in modern art thus retains its Beethovenian hubris; it is a Promethean act against the gods at a time when the gods have vacated the realms of meaning; it speaks as a heroic survivor. But inasmuch as Wellmer's aesthetic sublime presupposes a world that needs to be conquered, the sublime "relation" overcomes the other at the expense of reconciliation. 
sublime, as the aesthetic category that accompanies the monad, merely expresses the formal law of exclusion at the heart of the subject's sovereignty.

In a sense, Adorno knew that. His famous reversal of Hegel's definition of truth-"the whole is the false"-registers the delusion of monadic selfcompletion. Yet Adorno does not abandon the monadic work of art; instead he keeps faith with its moment of emancipation by pursuing its internal processes "until the inherent consequence of the [work] is transformed into [its] own criticism." 62 If the sublime monad is blind because it claims to see, then the truth of its lie can only be seen by blinding its vision. Myopia is the condition of its truth. ${ }^{63}$ What Adorno demands of art, then, is the revelation of its own monadic darkness in order to "illuminate a meaningless world." 64 Late Beethoven to late Schoenberg is Adorno's abridged history of this dialectical withdrawal into "absolute oblivion." 65 And it is by driving the isolation of the monad to the point of alienation in the formal laws of the Schoenbergian tone-row that art reflects the "horrors of history," forming an opaque mirror in which society might recognize itself. 66 The "shocks of incomprehension" that accompany new music are a result of this revelation: they testify to both the inaccessible truth of a windowless art that has "taken upon itself ... the darkness ... of the world" and a world that is blind to own darkness. ${ }^{67}$ So despite the dialectical negation of the monad from blinding light to illuminating darkness, the work of art ultimately retains its nonreciprocal posture; it still has no eyes. Alienation, not relation, is Adorno's answer to the failure of humanism - as if the blind could lead the blind.

Beethoven's late works are the first to register the inhumanity of this blindness by pursuing the "formal law of freedom" to the point of self-negation. ${ }^{68}$ Buckling under their own pressure, the motivic and tonal structures lose the rigor of their internal order to reveal the exclusionary violence formerly masked by the aesthetic of purity. The formal law reveals its unfreedom through its formal collapse. By following an internal logic of disintegration, these late structures often betray the message of the work, particularly when its

62. Theodor W. Adorno, in Philosophie der neuen Musik, trans. Anne G. Mitchell and Wesley V. Blomster as Philosophy of Modern Music (London: Sheed and Ward, 2003), 133.

63. Or as Adorno puts it in Minima Moralia, 182: "micrological moral myopia." Not only does blindness undergo a dialectical reversal in Adorno's aesthetics, the sublime also inverts its effect, revealing the frailty of nature within the subject; see note 103 .

64. Adorno, Philosophy of Modern Music, 133.

65. Ibid.

66. Ibid., 132.

67. Ibid., 133. Also see Daniel K. L. Chua "Drifting: The Dialectics of Adorno's Philosophy of New Music," in Apparitions: New Perspectives on Adorno and Twentieth-Century Music, ed. Berthold Hoeckner, 1-17 (New York and London: Routledge, 2006); and Schoolman, "Toward a Politics of Darkness," 57-92.

68. In the late style, writes Adorno, the "formal law is manifest ... precisely in reflection on death" (Beethoven, 125). 
humanism is announced with the monumental voice of the hero; the epic proportion with which Beethoven makes the declaration of peace in the Missa solemnis, for example, or the politics of joy in the Ninth Symphony no longer generates the inner discipline that pulls the material into a taut, tensile form; instead, their formal disintegration divulges the "dark side" of human freedom. At times, this inhumane element is not even sublimated as a structural undertone; in the finale of the Ninth Symphony, what Agamben would classify as "a state of exception" in which sovereignty is established by the law of exclusion, is explicitly portrayed; all are included in the brotherhood of joy with the exception of its Other- "he who cannot rejoice."69

Whoever has the great fortune to enjoy mutual friendship,

Whoever has taken a loving wife, let him join us in celebration!

Yes! Even he who calls only one single soul his own in all the wide world!

But he who cannot rejoice, let him steal weeping away from this group. ${ }^{70}$

Schiller's poem states this political order seemingly without embarrassment, but Beethoven sets the injunction for the Other "to steal away" with a counterintuitive dynamic that illumines the ban that gives joy its sovereignty (see Ex. 1). The emphatic cadence that normally punctuates the "joy theme" with a loud flourish closes with a rather awkward "diminuendo-piano," as if the music needed to hide an anomaly at this point (mm. 280-284 and 288292)..$^{71}$ The theme's embarrassment is, in one sense, merely word paintingthe music steals quietly away-but in doing so, the sudden hush brings out the contradiction between the inclusiveness of joy and its necessary exception by impeding the dynamic flow. So for all its heroic noise, the celebration of brotherhood in the theme harbors a quiet blush that gives away its lie, for the humanism it champions treats its Other as less than human.

But for Adorno, it is the Missa solemnis that represents the shrine of human alienation. In this work, the state of exception is so radical that the excluded

69. If, as Agamben contends in Homo Sacer, the structure of sovereignty has at its heart the inclusion of what it simultaneously excludes (the illegal exception), then the inclusion of the exception in Schiller's text founds the sovereignty of joy; joy abandons those whom it is bound to protect as subhuman in the name of humanism. Also see note 267.

70. Wem der grosse Wurf gelungen, / Eines Freundes Freund zu sein, / Wer ein holdes Weib errungen! / Mische seinen Jubel ein! / Ja-wer auch nur eine Seele / Sein nennt auf dem Erdenrund! / Und wer's nie gekonnt, der stehle / Weinend sich aus diesem Bund.

71. For further discussion of exclusion in the Ninth's message of harmony see Nicholas Vazsonyi, "Hegemony Through Harmony: German Identity, Schiller, and the Ninth Symphony," in Sound Matters: Essays on the Acoustics of German Culture, ed. Nora M. Alter and Lutz Koepnick, 33-48 (Oxford and New York: Berghahn, 2004); and Peter Tregear, "The Ninth after 9/11," Beethoven Forum 10 (2003): 221-32. Also see Adorno's comments on this passage in Beethoven, 32-33 and 212; Adorno draws attention to the "affirmative force with which Beethoven hammers [the idea of humanity] home" (212); the forte passages that surround the lines are just as guilty in their insistence as the "diminuendo-piano" blush. 
Example 1 Beethoven, Symphony No. 9 in D Minor, Op. 125, finale, mm. 284-292 (Chorus)

S.

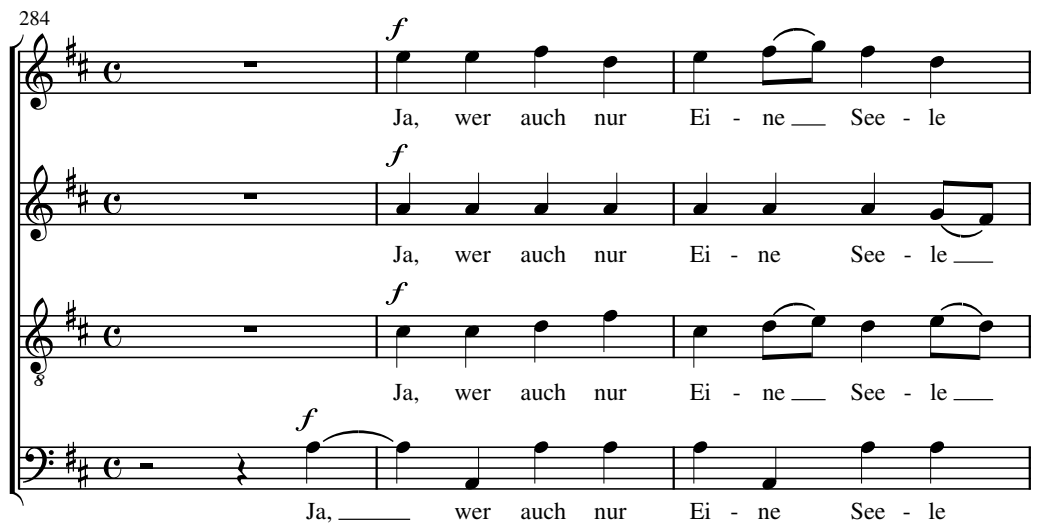

S.

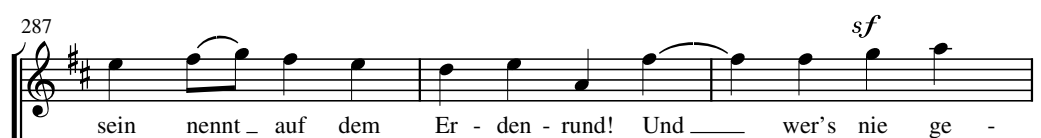

A.

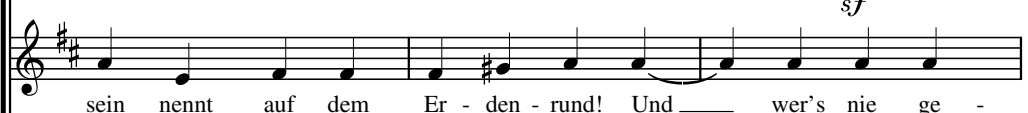

0
0
0

T.

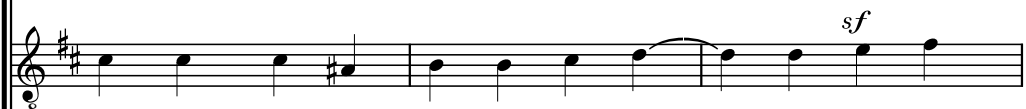

B.

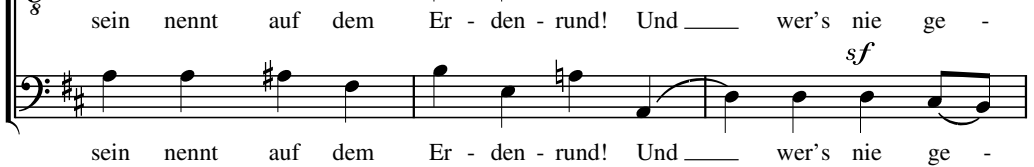

S.

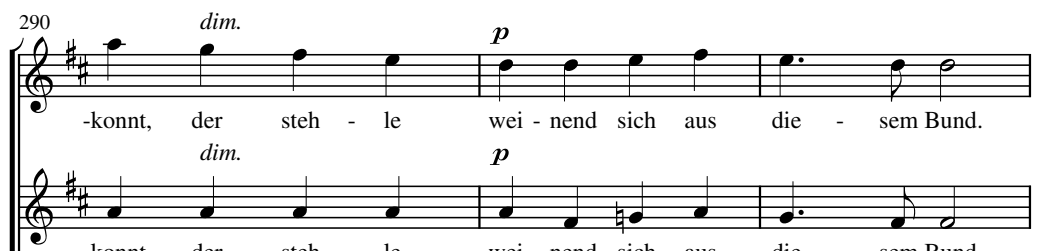

A.

๑)

$\mathrm{T}$.

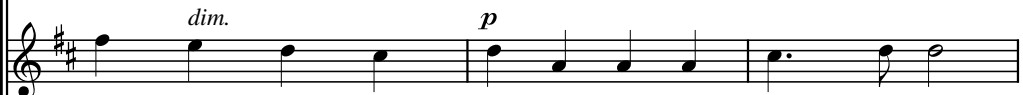

\& -konnt, der steh - le wei - nend sich aus die - sem Bund.

B.

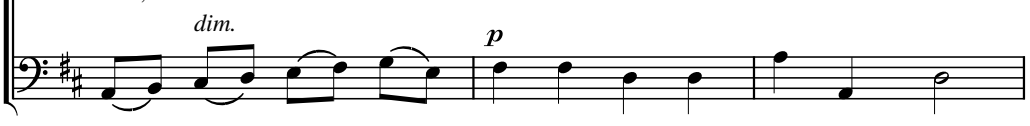

-konnt, _ der__ steh - le__ wei-nend sich aus die - sem Bund. 
Other is none other than Beethoven himself. ${ }^{72}$ The composer has been banished from his own music. Beethoven's "greatest work,"73 as he himself advertised it, betrays its "greatness" with a disconcerting reticence, as if this were another blush, hiding by instinct rather than intention a secret that undermines Adorno's faith in Beethoven's power to solve the "riddle of humanity."74 The heroic Augenblick, notes the philosopher, derives from a composer whose power "is founded on humanity and demythologization," but "the Missa's formal law," is a curtailment of that power, rendering the mass strangely impotent, as if "it cannot say what it . . . sets out to say": Beethoven has simply "eliminated himself" to produce a monumental blank. ${ }^{75}$ Instead of the dynamic impulse that generates the totality from the friction of the motivic particulars, the Missa is constructed out of arbitrarily imposed blocks of anonymous material. "The autonomous subject," writes Adorno, "which knows itself to be capable of objectivity in no other way, cedes to heteronomy."76 Beethoven's internal law of freedom is now subject to external laws that resemble the archaic order from which his music had emancipated itself, except that this order is not a reactionary return of the disciplinary function of religion, as the mass setting would suggest, but a secular abstraction. In effect, the heroic monad has excluded itself, leaving a power vacuum for an outside authority to take hold of the present in the guise of a religious anachronism. With its formal law purified of the subject, the objectivity of what remains is the god to whom Beethoven has sacrificed his music. And Adorno is uncertain whether he can pray Beethoven's demythologized prayer for the future of humanity.

72. "Hardly anyone who did not know [the Missa]," observes Adorno in Beethoven, 139, "could tell by listening to the work that it was by Beethoven." "It lacks all unmistakably Beethovenian characteristics."

73. In a letter to Verlag Schott of 10 March 1824, Beethoven writes "I consider [the Missa solemnis] my greatest work.” Beethoven, Sämtliche Briefe, ed. Emerich Kastner, rev. Julius Knapp (Tutzing: Hans Schneider, 1975), 706.

74. Adorno, Beethoven, 8. In fact, it was on account of the Missa solemnis that the philosopher abandoned his Beethoven project altogether. In the preface to Moments musicaux Adorno writes: "The [essay] 'Alienated Masterpiece' ... forms part of the complex philosophical work on Beethoven projected since 1937. It has yet to be written, mainly because the author's efforts have continually foundered on the Missa solemnis. He has therefore tried at least to set out the reasons for these difficulties, and to state the question more precisely, without presuming to have answered it." Translation is from Adorno's Beethoven, $235 \mathrm{n} 249$ (slightly altered). Original: “'Verfremdetes Hauptwerk' . . gehört in den Komplex des schon seit 1937 projektierten philosophischen Werkes über Beethoven. Bislang kam es nicht zur Niederschrift, vor allem, weil die Anstrengungen des Autors immer wieder an der Missa Solemnis scheiterten. Er hat darum wenigstens versucht, den Grund jener Schwierigkeiten zu benennen, die Frage zu präzisieren, ohne sich anzumaßen, er hätte sie etwa schon gelöst." Adorno, Moments musicaux, in Musikalische Schriften IV, vol. 17 of Gesammelte Schriften, ed. Rolf Tiedemann (Frankfurt am Main: Suhrkamp, 1982), 12.

75. Adorno, Beethoven, 142, 139, 151, and 139.

76. Ibid., 152 . 


\section{The Human}

What is it to be human? This is the question that Adorno asks Beethoven to answer. Despite falling to the thrall of the Beethovenian hero, there are moments in which Adorno refuses to give the heroic monad the monopoly it desires over humanism. There exists another vision, one that contradicts the blind autonomy of the hero and his myopic withdrawal into hermitic darkness. Very occasionally, Adorno sees it. Or rather, it is the other way round: the vision sees Adorno. The music has eyes, he claims. And although this gaze is left almost inarticulate in his fragments on Beethoven, Adorno sees in these eyes the secret of what it is to be human: "In what does the expression of the human manifest itself in Beethoven? I would say, in the fact that his music has the gift of sight. The human is its gaze." 77 This "gaze" is clearly indebted to Walter Benjamin's concept of "aura," a phenomenon that endows a work of art with "the ability to look back at us." "78 As such, this gaze is far more startling than the hollow sockets that haunt Adorno in Beethoven's late works, for the "auratic individuality" of an object demands a returning glance. ${ }^{79}$ What is human expresses itself only in relation to another. And by "an Other" Adorno means another so different that $\mathrm{s} / \mathrm{he}$ is almost nonexistent; these eyes open like windows onto a human being long forgotten by the modern subject. In this gaze, the subject is disarmed of the instrumentality with which it habitually "violate[s] the imponderably delicate aura of the other," as Adorno puts it. ${ }^{80} \mathrm{Or}$ in the words of Lévinas, "the face of the other" puts the self "into question." ${ }^{81}$ The "totalizing look" of the hero is suddenly surprised by the alterity of a face that precedes his initiative and eludes his autonomy, demanding a response from one who normally only commands in the name of freedom..$^{82}$ It is the subject's ability to avert this gaze, or perhaps to stare through

77. Ibid., 164.

78. Walter Benjamin, "On Some Motifs in Baudelaire" in Illuminations, ed. Hannah Arendt, trans. Harry Zohn (London: Fontana Press, 1968), 184; translation slightly modified. Benjamin uses the term to denote both the authenticity of artworks and the uniqueness of an individual person. The latter is particularly relevant since Benjamin associates this aura with the gazing face captured in early photographs: it represents the human, a presence that will vanish in later photography, which not only swallows the subject into the background but attempts to make individuals appear identical. Thus "aura" evokes a human being whose existence is barely present under the destructive conditions of modern life. For a summary of Benjamin's use of the term see Miriam Bratu Hansen, "Benjamin's Aura," Critical Inquiry 34 (2008): 336-75; for an exploration of the relation between Adorno and Benjamin on photography see Shierry Weber Nicholsen, Exact Imagination, Late Work: On Adorno's Aesthetics (Cambridge, MA: MIT Press, 1997), 181-225.

79. On "auratic individuality" see Bernstein, Adorno: Disenchantment and Ethics, 111-20.

80. Adorno, Minima Moralia, 182.

81. Lévinas, "Diachrony and Representation," 168.

82. See Emmanuel Lévinas, Alterity and Transcendence, trans. Michael B. Smith (London: Athlone Press, 1999), 22-32, and 4. 
it, that constitutes the inhumanity of modern society. "For Adorno, this exchange of looks" comments J. M. Bernstein, "of seeing and not seeing, of being seen and disregarding this seeing" lies at the core of the subject's moral disintegration. ${ }^{83}$ What is human, then, is not disclosed in the eyes, as if it could be appropriated by the subject, but is realized in our relation to the gaze. It takes at least two to be human.

So if Beethoven's music has eyes, if "the human is its gaze," then our very being, to return to Lévinas's phrase, will be "put into question" by the music. Perhaps this was Adorno's original motivation for his unfinished project on the composer: Beethoven seemed to be staring him in the face. In one of his earliest notebooks, just before the first jottings on the Beethoven monograph, Adorno scribbled to himself: "We do not understand music-it understands us . . Just when we think ourselves closest to it, it speaks to us and waits with sad eyes (mit traurigen Augen) for us to answer." 84 These "sad eyes" initiate a reversal. Our investigation of music suddenly turns on "us"; it is about "us"; "it understands us"; it puts "us" into question. Moreover, our knowledge of music is inversely proportional to our self-knowledge; the more we understand it, the less we understand ourselves. Its alterity turns the "I am" of modern self-affirmation into a question: "Who am I?" And it is our inability to answer the question - our inability to be human - that leaves those eyes waiting for the reciprocity that will turn alienation into relation.

Indeed, Rolf Tiedemann speculates that Adorno's failure to complete his Beethoven project stems from our incapacity to be human after Auschwitz. How could the "societal monad" as Adorno calls us, ${ }^{85}$ answer those sad eyes “in an age when the 'better worlds' of which Florestan sang were no more than a blood-stained mockery of this present world, beside which Pizarro's dungeon appears idyllic"?\$6 Initially, Adorno had wanted his Beethoven monograph "to resolve the riddle of humanity," 87 but in the end, given the blindness of society to its own inhumanity, he could only affirm the riddle's insolubility as the answer. ${ }^{88}$

But the failure of the Beethoven project was not merely the result of an untimely history. The problem lies deeper, entangled within Adorno, in the inability of his very thoughts to think the human. Adorno's failure, then, is also the failure of philosophy itself. Beethoven: The Philosophy of Music simply could not live up to the philosophy it aspired to in its title, for within the

83. See Bernstein, Adorno: Disenchantment and Ethics, 72 . On this "manic gaze" that cannot see the human except as a thing, see Adorno, Minima Moralia, 105.

84. Adorno, Beethoven, xi; translation slightly modified.

85. Theodor W. Adorno, "Education After Auschwitz" in Critical Models: Interventions and Catchwords, trans. Henry W. Pickford (New York: Columbia University Press, 1998), 201.

86. Adorno, Beethoven, xii.

87. Ibid., 8 .

88. In Aesthetic Theory, 122, Adorno writes: "The solution of the enigma amounts to giving the reason for its insolubility, which is the gaze artworks direct at the viewer." 
philosophical tradition Adorno inherited, the question of personal ontology is actually an impossible one. According to the theologian John Zizioulas, the question "Who am I?" has no answer in Western philosophy; "Ancient Greek thought [is] essentially 'non-personal,' " he writes. ${ }^{89}$ And if there is no answer, then the gaze that Adorno glimpses in Beethoven will be left unreturned, destined for alienation and not relation. Indeed, the gaze itself would be suspended as an eternal riddle- "Who am I?" Yet the three components in the question outline a metaphysics of personal identity without which humanity ceases to be human. The first component, the "who," is a "call for definition," states Zizioulas; it is the self-assertion of a consciousness that must articulate its identity against a given world. The second component, the "am," is a statement of being; it is the desire to transcend the transience of existence, to secure the need to be in the face of non-being. Finally, the component "I," is "a cry for particularity"; it is an assertion of otherness, a claim to a uniqueness that is both unrepeatable and nontransferable - "many things 'are' but no one else is me." being into a metaphysics of the particular. And this is precisely the impossible thought of Western philosophy that Adorno wants to think in Beethoven. In Platonic and Aristotelian thought, true being cannot be attached to the particular. Being is eternal; the particular is transient and partakes of metaphysics only as a by-product of some totality. So in Plato, the particular finds its true identity in the universal; the particular fades away but the form in which it participates remains. Form is, therefore, eternal. In Aristotle, the particular is a classification of nature. If "the individual [exists only] within a genus," as Lévinas points out, then the "I" is always replaceable; 91 the class survives its ephemeral status only as a member of a species. Nature is, therefore, eternal.

Although Adorno operates critically against both tendencies, conflating the totalizing and classifying habit as forms of "identity thinking," he nevertheless succumbs to the universal in typically Greek fashion: the particular's existence is played out as tragedy. Greek tragedy, writes Zizioulas, confirms its philosophy: the cosmos "does not exist for the sake of man, but man exists for its sake." The premise of Adorno's thought is one in which the individual is enslaved by the external order and is ultimately annihilated by the totality. In Horkheimer and Adorno's Dialectic of Enlightenment, reason reverts to myth, turning history into fate. The same narrative underlines Adorno's history of music; ${ }^{93}$ the

89. John D. Zizioulas, Being as Communion: Studies in Personhood and the Church (London: Darton, Longman and Todd, 1985), 27.

90. John D. Zizioulas, "On Being a Person: Towards an Ontology of Personhood," in Persons, Divine and Human, ed. Christoph Schwöbel and Colin E. Gunton (Edinburgh: T \& T Clark, 1991): 34-35.

91. Lévinas, "Diachrony and Representation," 168.

92. Zizioulas, Being as Communion, 32.

93. Adorno regarded Philosophy of Modern Music as "an extended appendix" to the Dialectic of Enlightenment; see Adorno, Philosophy of Modern Music, xiii-xiv, and Chua, "Drifting," 5. 
heroic Beethoven, writes Adorno, is "the metaphysics of tragedy - the totality of negations as a position, the affirmation of what is"; the late works are supposed to unmask this "tragedy as illusion," but they still end up as "catastrophes" in which "the destruction of the particular" takes center stage. ${ }^{94}$

Thus the vision of humanity that Adorno perceives in Beethoven's eyes merely questions the tragedy with an alterity that suspends the total domination of fate, but it cannot constitute a true metaphysics of the particular. This music, he writes, "is perceived only as something vanishing from sight. As Eurydice was seen." 95 So the closest his philosophy of music gets to making eye contact with the particular is in the gaze between Orpheus and Eurydice, in which the act of reciprocity destroys its very possibility. The human-the impossible thought-is sustained only by that which fades away: an apparition. And if the truth of the particular for Adorno is its enduring transience, then this merely turns the question "Who am I?" into "What am I?" (I am transient); and the "what" is precisely that which is not particular, for transience is a transferable and repeatable quality shared by the many.

In effect, Adorno's vision of transience reduces a person to a thing-from "who" to "what." This is particularly telling in Adorno's cosmic metaphor of "stars" that appear fleetingly in Beethoven's works. These "humanized star[s]" are like eyes that twinkle above the totality; 96 they are extraneous particulars whose flicker rhymes with "the imponderably delicate aura of the other." " And yet, if the eyes are constellations, the cosmic analogy of them closing in death and reopening in nature seems too close to Platonic and Aristotelian thought to affirm the ontology of the particular. ${ }^{98}$ Ultimately, the

94. Adorno, Beethoven, 176, 126, and 177.

95. Ibid., 6; italics added. On this motif in Adorno see Daniel K. L. Chua, "Adorno's Metaphysics of Mourning: Beethoven's Farewell to Adorno," Musical Quarterly 87 (2004): $530-32$.

96. Adorno, Beethoven, 170. Adorno's aesthetic theory aligns art's permanent "image" with the social totality against which the "star" or its kindred spirit the "apparition" falls or fades as a fleeting spectre of otherness; this "instant of appearance" [Augenblick des Erscheinens] within the image demonstrates a metaphysics of alterity where the nonidentical rises above the identical (Aesthetic Theory, 80).

97. Adorno, Minima Moralia, 182.

98. Music's inorganic afterlife in nature is already evident in some versions of the Orpheus myth; after Orpheus's decapitation, Apollo places his lyre among the stars. Or as Adorno himself writes: "If the idea of artworks is eternal life, they can attain this only by annihilating everything living within their domain" (Aesthetic Theory, 52). This connection between death and starlight is particularly evident in a quote from Louis Aragon which Adorno uses to preface his essay "Schubert," in Moments musicaux (18): "The whole useless body was invaded by transparency. Little by little the body turned to light. The blood shone. The limbs, in an incomprehensible gesture, became rigid. And the person was no longer anything but a sign among the constellations." By fixing non-identity among the stars, Adorno is merely re-inscribing the basic premise of western metaphysics and therefore the problem of personal ontology. Beethoven, incidentally, was drawn to the starry heavens above; see, for example, William Kinderman, "Beethoven's Symbol for the Deity in the Missa solemnis and the Ninth Symphony," 19th-Century Music 9 (1985): 
human being is not a human being for Adorno but an adjunct to being added as "something extra-human." 99 Indeed, the thrust of Adorno's aesthetics in which the mimetic rationality of art hopes to reconcile nature to the abstract rationality of the Enlightenment tends to return a humanity that defines itself against nature back to its origins in nature. ${ }^{100}$ Admittedly, it is not nature as such but its evanescent, almost inimitable beauty that art imitates. But natural beauty as the nonidentical trace in art's mimetic impulse can fall prey to that Teutonic desire to merge with the Earth, ${ }^{101}$ a trope that manifests itself in the Primal Unity of Schopenhauer's metaphysics and the death-wish of Mahler's music. After all, doesn't Adorno describe Eurydice's farewell as "the tears of one whom the earth has reclaimed"? 102 It is this "gesture of return," he writes, that "characterizes the expression of all music."103 Adorno's twist on metaphysics, then, is that the permanence of nature has become transienthence the stars are always falling stars. The particular is ephemeral because nature decays; its earthly return is therefore a reconciliation with nature as death. The appearance of nature as the Other is simultaneously the spectacular disap-

102-18; and Berthold Hoeckner, Programming the Absolute: Nineteenth-Century German Music and the Hermenentics of the Moment (Princeton, NJ: Princeton University Press, 2002), 12-50 and 224-37. On Orpheus's inorganic afterlife see Daniel K. L. Chua, "Untimely Reflections on Operatic Echoes: How Sound Travels in Monteverdi's L'Orfeo and Beethoven's Fidelio with a Short Instrumental Interlude," Opera Quarterly 21 (2005): 577.

99. Adorno, Beethoven, 170. Also see Zizioulas, Being as Communion, 39.

100. Adorno, in Beethoven, 173, puts this idea succinctly: "Nature, having become the ego, opens its eyes as ego (not in the ego, as its regressive part) and becomes aware of itself qua ego as nature. This moment-that is, not the breakthrough of nature but its remembrance of otherness-is closest to reconciliation and also to lamentation"; this modified translation is from Hoeckner, Programming the Absolute, 237. Although the "non-identical" for Adorno implies the possibility of an Other human, his exploration of this idea in his aesthetic tends not to be personal; rather he locates alterity in natural beauty, which means that the individual is ultimately reducible to nature and death.

101. Adorno writes: "Natural beauty is the trace of the nonidentical in things under the spell of universal identity" (Aesthetic Theory, 73). Thus the star, as an object of nature, is "a promise of goodness. The gesture of nature as good" (Beethoven, 170). On natural beauty and non-identity see Aesthetic Theory, 71-78; on mimesis and nature see ibid., 110-12, 133-34, and 167-69.

102. Adorno, Beethoven, 184. Aptly, this reference to the Adagio of Beethoven's Sonata, Op. 31, no. 2, does not concern only Eurydice's tears but also the stars; see the parallel passage on Opus 31, no. 2, in Beethoven, 170.

103. Adorno, Philosophy of Modern Music, 129. These tears refer to an automatic release from the eyes of modern music; just as an involuntary blush recalls our instinctive, pre-subjective state in nature, so these musical tears of a cold and objective modernity are a natural release not too different from the distant twinkle of a star. Also see a parallel passage in Aesthetic Theory, 276, that associates these tears with a sublime self-awareness: in the face of nature, the subject, contra Kant and the heroic Beethoven, becomes aware of its own natural essence which "breaks the arrogance of his self-positing"; thus "freedom awakens in the consciousness of its affinity with nature." Or as Wellmer puts it: "Modern art is the remembrance of nature in the subject, tied to the power of a subject to withstand the experience of its own natural condition" ("Adorno, Modernity, and the Sublime," 166). 
pearance of the particular. Or as Berthold Hoeckner puts it: "Only at the moment of its fall does the star shine brightest."104

Inasmuchas Adorno reduces the person to nature, there is something necessarily cold about these starry eyes despite their evanescent glow. In fact, Adorno's philosophy is colder than the mere indifference of nature, for nature's transience is at the beautiful end of the mimetic spectrum in which the particular is suspended. The instrumentality of modern reason that distances the world as an object of dissection stands at the other end; it too is a mimesis of nature. Instrumental reason, write Adorno and Horkheimer, is the "mimesis of death" in nature, ${ }^{105}$ but this time it results in a permanent death brought on by the chill of Enlightenment thought. Instead of the ephemeral passing of the subject, this demise is the "Eternal Recurrence" of the same;106 it is the rigor mortis of fate, of myth, of the living dead. As Simon Jarvis explains, for Adorno the mimesis of nature in the magical rituals of primitive man is

[an] attempt to become like nature in order to ward off what is feared [in nature]; but what remains to be feared when instrumental reason has apparently brought a feared nature under culture? Death is an inextinguishable reminder of the nature in culture. The whole nexus of self-preservatory thought and action ... mimics death, strives to become inorganic, object-like in its attempt to ward off death. ${ }^{107}$

Thus the mimesis of nature is both the "Other" of Enlightenment reason and, in its "repressed form," an identification with it. 108 The particular is torn between two deaths, frozen between the eternity of one and the passing of the other. The coldness of this dialectical deadlock, for Adorno, is an attempt to outwit fate by dying to death, stalling the tragedy through the negation of the negative. It is as if, in the subzero temperatures of this philosophy, the particular is cryogenically preserved in art until a cure for humanity's coldness is found. In Beethoven's late works, the friction generated between the two deaths is allegorized as the collision between the objective debris of classical conventions (stasis) and the fiery hollows of the escaping subject (transience). It causes sparks that illuminate the splintered landscape. Such a moment is redemptive, for Adorno, because these sparks "estrange the world, reveal[ing] it to be, with its rifts and crevices, as indigent and distorted as it will appear one day in the messianic light."109 But this light cannot banish the coldness from the deaths in which the particular is ensnared; it illuminates it "harshly" as a revelation of darkness. ${ }^{110}$ Thus according to Adorno's thermometer, the

104. Hoeckner, Programming the Absolute, 23.

105. Adorno and Horkheimer, Dialectic of Enlightenment, 57; translation modified.

106. Theodor W. Adorno, "Stravinsky: A Dialectical Portrait," in Quasi una Fantasia: Essays on Modern Music (1963), trans. Rodney Livingstone (London: Verso, 1992), 152.

107. Simon Jarvis, Adorno: A Critical Introduction (New York: Routledge, 1998), 31.

108. Adorno and Horkheimer, Dialectic of Enlightenment, 187.

109. Adorno, Minima Moralia, 247.

110. Adorno, Beethoven, 126. 
temperatures in these works fluctuate feverishly between a frozen landscape where "subjectivity has petrified" and fleeting fires "ignited by subjectivity as its strikes the walls of the work in breaking free." This "ignition between extremes" inaugurates the truth of music in the shivering climate of modernity. ${ }^{11}$

So whatever warmth is conjured up in the glimmers of ghosts and stars in Adorno"s hearing of Beethoven, it cannot thaw what he calls "the coldness of the societal monad." 112 There is a chill in the eyes of humanity because coldness for Adorno constitutes the fundamental principle of modern society. It "permeates everything"; 113 the stoical hardness of Kantian ethics, the political and aesthetic theories of mutual disinterest, and ultimately the atrocities of Auschwitz are all manifestations of it. ${ }^{114}$ As Adorno writes:

$\ldots$ if people were not profoundly indifferent toward whatever happens to everyone else except for a few to whom they are closely bound and, if possible, by tangible interests, then Auschwitz would not have been possible, people would not have accepted it. ... [The "lonely crowd" is] a banding together of people completely cold who cannot endure their own coldness and yet cannot change it. ${ }^{115}$

This chill is so pervasive that even Adorno's method of critique cannot but collude with the same "coldness that is the fundamental principle . . o of bourgeois subjectivity"; the "reflective coldness of the theorist" cannot escape the guilt of that which it decries. ${ }^{116}$ Hardness is the condition of a critique in hard times. And, ultimately, the humanity that Adorno sees in Beethoven's eyes is no different; the eyes become cold. In fact, he specifically aligns Beethoven's gaze to a moment of critical resistance in the Ninth Symphony. What Adorno sees is a steely vision engaged in some kind of staring contest with fate. These eyes pierce through the recapitulation of the first movement, where the power of the principal theme resonates within the recipient as a sublime "shudder" of overwhelming fear; ${ }^{117}$ the sheer volume and rhythmic insistence affirm the return of the opening as fate. ${ }^{118}$ By imposing the "recurrence of the same," the recapitulations in Beethoven's heroic symphonies often "assume the crushing force of repression" for Adorno, "of an authoritarian 'That's how it is.' "119 With the Ninth, this force is particularly terrifying. The reappearance of the sotto voce opening as a cacophonic blaze of $\mathrm{D}$ major is almost an exaggeration

111. Ibid.

112. Adorno, "Education after Auschwitz," 201.

113. Ibid., 202.

114. See Bernstein, Adorno: Disenchantment and Ethics, 400-406.

115. Adorno, "Education After Auschwitz," 201.

116. Bernstein, Adorno: Disenchantment and Ethics, 398. "The detached observer," writes Adorno in Minima Moralia, 26, "is forced to develop a coldness indistinguishable from that of the bourgeois."

117. Adorno maintains that Beethoven's recapitulations are "aesthetically dubious," the "moment of untruth, of ideology" (Beethoven, 17).

118. Adorno, Aesthetic Theory, 245.

119. Adorno, Beethoven, 44. 
of the minor-major trajectory so typical of Beethoven's heroic forms; in this struggle from darkness to light, what was suppressed in a mysterious haze at the beginning is now revealed as an act of such violence that some commentators have compared this recapitulation to attempted rape and ritual murder. ${ }^{120}$ And yet, for Adorno, the "shudder" of the recoiling subject in such moments of structural necessity produces a counterforce that stares fate in the face; in Kantian fashion, it shakes the "I" into an awareness of an ethical sublimity within itself that can withstand the limits imposed by an authoritarian world. And it is this reaction that is embodied in the theme in the reprise of the Ninth Symphony; its recapitulation does not merely reinforce the "pure representation of necessity," which Adorno hears at the beginning, but resists it. ${ }^{121}$

But how? Adorno does not say, but perhaps it is due to an emerging sense of difference in the music. The return of the theme is not as monolithic as its force makes out, but is split by an internal struggle that turns the moment of structural synthesis into one of resistance. This is significant, for at the start of the symphony the original theme drives ineluctably toward the singular, asserting its tonal identity at its point of closure with the raw power of an unharmonized arpeggio blasted out by the orchestra (Ex. 2a, mm. 16-21).122 Even the initial fragments that hover nebulously over the opening measures are monophonic in essence; the apparent harmony of bare fifths is not some separate entity that complements the falling motifs, but is merely the result of a single outline that encompasses the melodic surface and bass support (Ex. 2b); they are one and the same, forming a kind of a unison haze.

At the recapitulation, however, this outline, despite its terrifying volume, is undermined by recalcitrant bass notes that generate strange harmonies, preventing the melodic force above from grounding itself below. The bass line shifts its footing in a highly unorthodox manner that flouts the laws of "good" voice leading: $\mathrm{F} \#-\mathrm{B} b-\mathrm{A}-\mathrm{F}$ ( $(\mathrm{mm}$. 301-315). Perhaps this is because it isn't supposed to be "good"; rather the bass line forms a rogue element. The initial $\mathrm{F} \#$, for example, turns the open fifths of the theme (D-A) into a triumphant D-major triad, but far from colluding with this "crushing force of repression," it quite literally up-roots the sonority so that it teeters precariously as a first inversion chord; the $\mathrm{F} \#$ is foreign to the structural weight that the theme claims for itself. The purpose of these peculiar bass notes, it seems, is to produce a sense of melodic stasis by warping the harmonies around the theme; instead of

120. See Robert Fink, "Beethoven Antihero: Sex, Violence, and the Aesthetics of Failure, or, Listening to the Ninth Symphony as Postmodern Sublime," in Beyond Structural Listening? Postmodern Modes of Hearing, ed. Andrew Dell'Antonio, 109-53 (Berkeley: University of California Press, 2004); and Susan McClary, Feminine Endings: Music, Gender, and Sexuality (Minneapolis: University of Minnesota Press, 1991), 128-29.

121. Adorno, Beethoven, 15.

122. In this example, the exception to the unharmonized sound are the trumpets which reinforce the percussive blows of the timpani; the timpani are obviously limited in terms of pitch, resulting in the anomaly, but Beethoven has hidden the limitation by ensuring that the downbeats remain unharmonized. 


\section{Journal of the American Musicological Society}

Example 2 Beethoven, Symphony No. 9 in D Minor, Op. 125, first movement, exposition:

(a) $\mathrm{mm}$. 16-21; (b) mm. 1-5

(a)

$2 \mathrm{Fl}$

$2 \mathrm{Ob}$

(Sib)

$2 \mathrm{Fg}$.

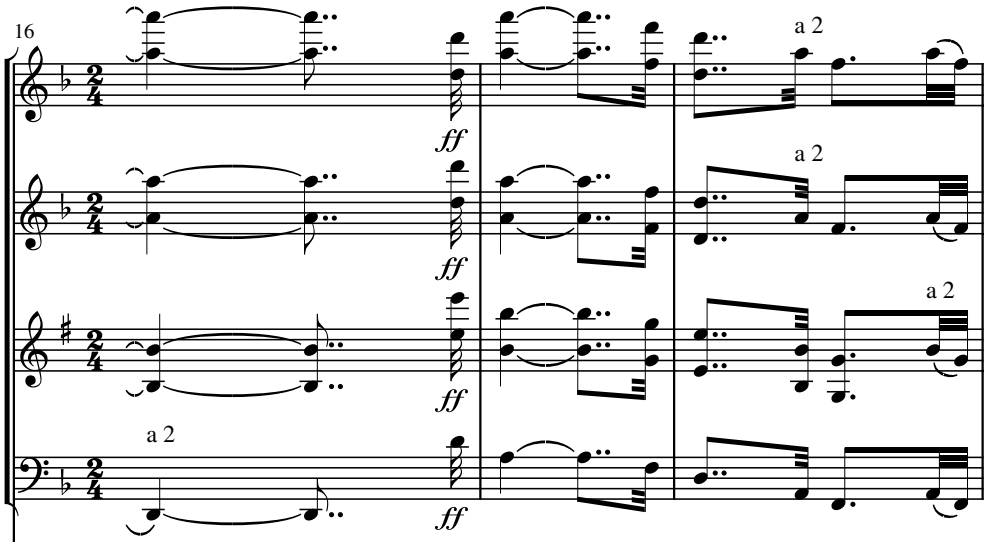

2 Cor

(Re)

2 Cor.

(Sib)

$2 \mathrm{Tr}$.

(Re)

Timp.

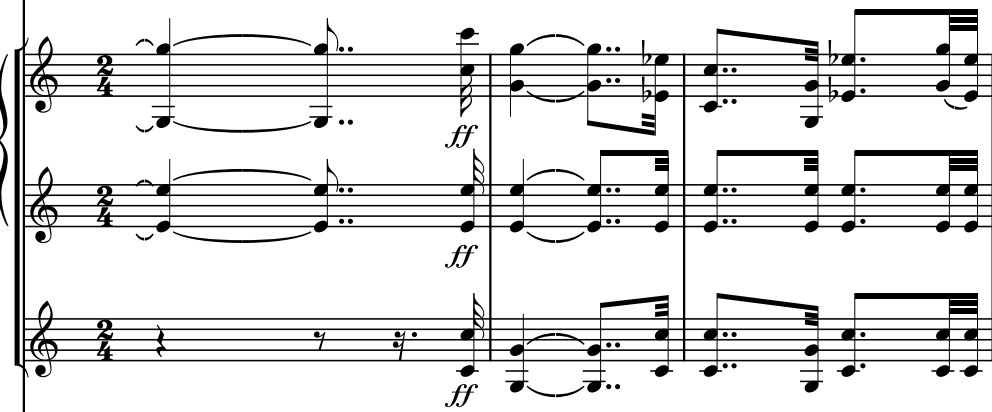


Example 2 continued

$2 \mathrm{Ob}$.

$2 \mathrm{Cl}$.

( $\mathrm{Sib}$ )

$2 \mathrm{Fg}$.

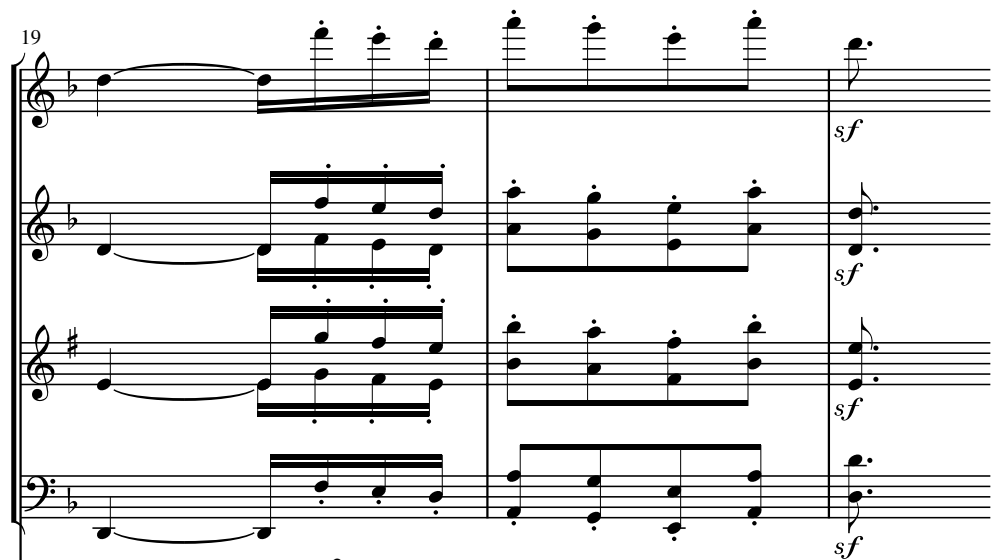

2 Cor.

(Re)

2 Cor

(Sib)

2 Tr.

(Re)

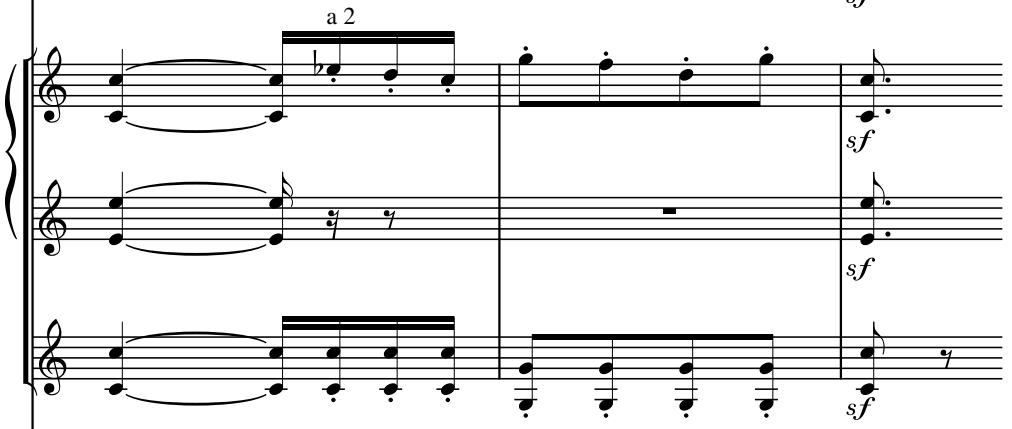

Timp.

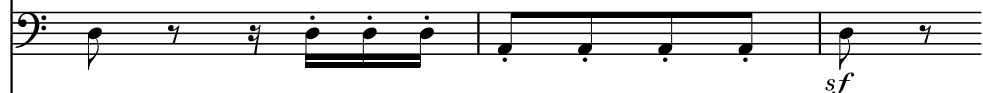

Vl. I

Vl. II

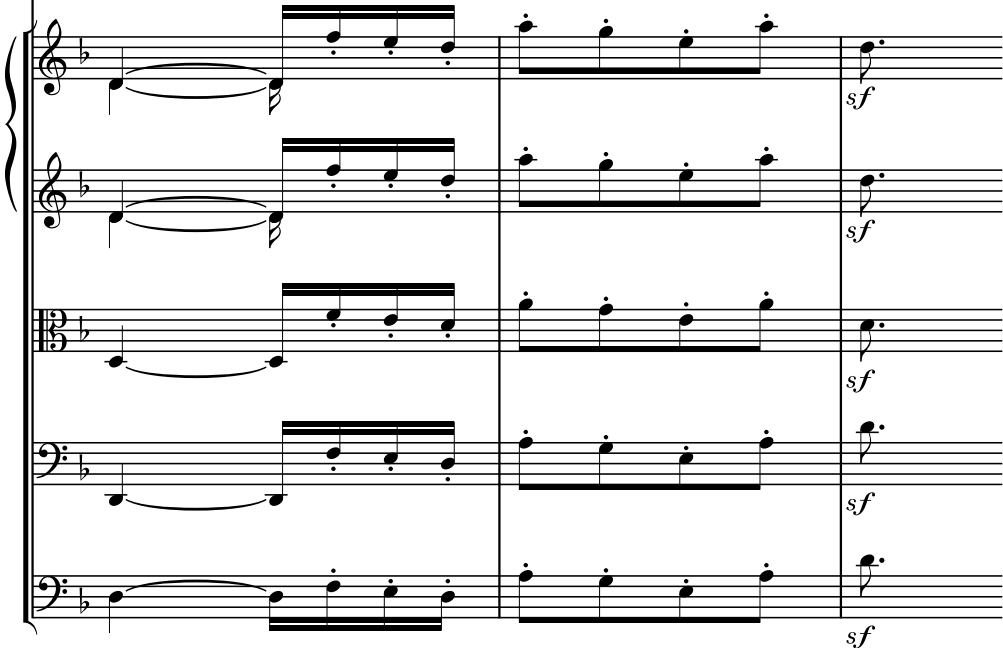


Example 2 continued

(b)

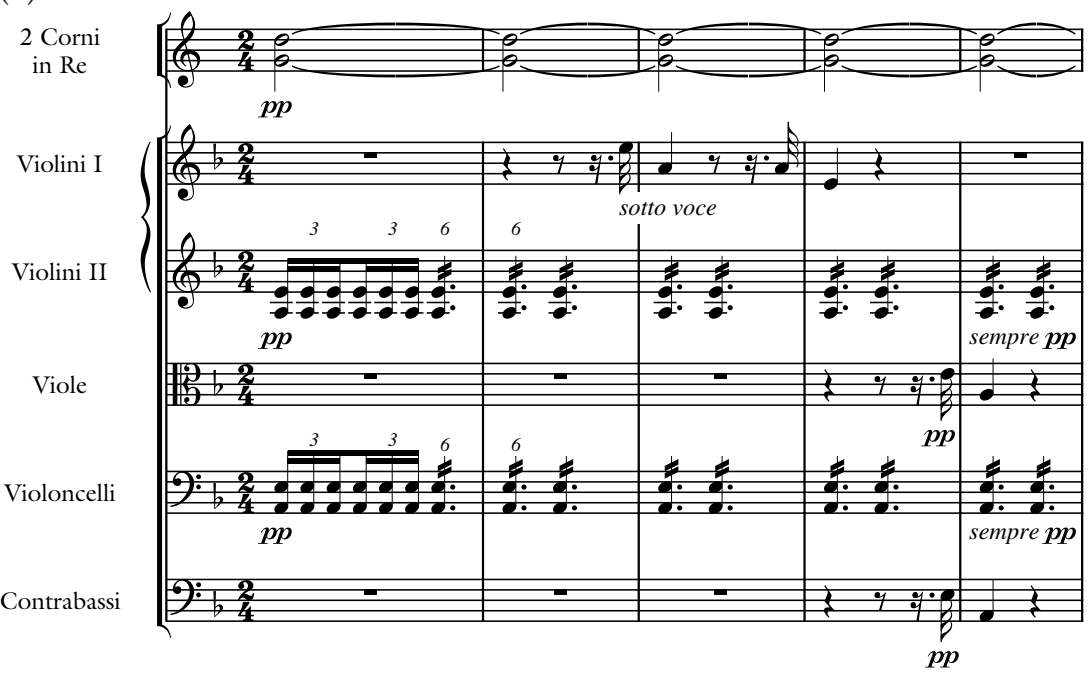

replicating the original dominant-tonic motion, the theme stagnates, as though it were caught within a harmonic force-field with D suspended inside. Thus the recapitulation is locked in a staring match. And to underline the stalemate, at the climactic moment in which the entire orchestra states the D-minor arpeggio in bare octaves, the bass refuses to align itself with the forces above it. Rather, it pushes upward in counterpoint against the downward trajectory of the arpeggio (Ex. 3).

The return of the initial theme, then, is Promethean; it has the "gesture of someone standing firm," writes Adorno. ${ }^{123}$ With its harmonic and contrapuntal defiance, the immediate force of the music is distanced by a gaze that holds back "the crushing force of repression." "The gaze of the work of art, which is manifested in this theme, and wants, through its meaning, to be gazed upon in turn, has something withstanding, resistant about it."124 Against the "Eternal Recurrence" of fate, the subject must continue to be, to affirm the "I am" of being, its freedom to exist. ${ }^{125}$ The "Who am I?" of the particular grates against the "Thus it is" of fate. ${ }^{126}$

\section{Adorno, Beethoven, 163.}

124. Ibid., 15.

125. Ibid., 152 .

126. Adorno, Aesthetic Theory, 245. The idea of the subject's sublime reaction to the sublime is more clearly exemplified in Adorno's description of the slow movement of the Ninth Symphony: "The gesture of standing firm is nowhere more grandiose than in the 12/8 section of the Adagio of the Ninth Symphony, where the fanfare of the full orchestra is answered, alone, by the first violins, but forte [m. 151]. The weak instruments stand up to the preponderant power, because fate has its limit in the human being, whose sound the violins are" (Beethoven, 113). 
Example 3 Beethoven, Symphony No. 9 in D Minor, Op. 125, first movement, recapitulation, mm. 314-321

$2 \mathrm{Fl}$.

$2 \mathrm{Ob}$

$2 \mathrm{Cl}$.

$2 \mathrm{Fg}$.

2 Cor.

(Re)

2 Cor.

(Sib)

$2 \operatorname{Tr}$.

$(\operatorname{Re})$

Timp.

Vl. I

Vl. II
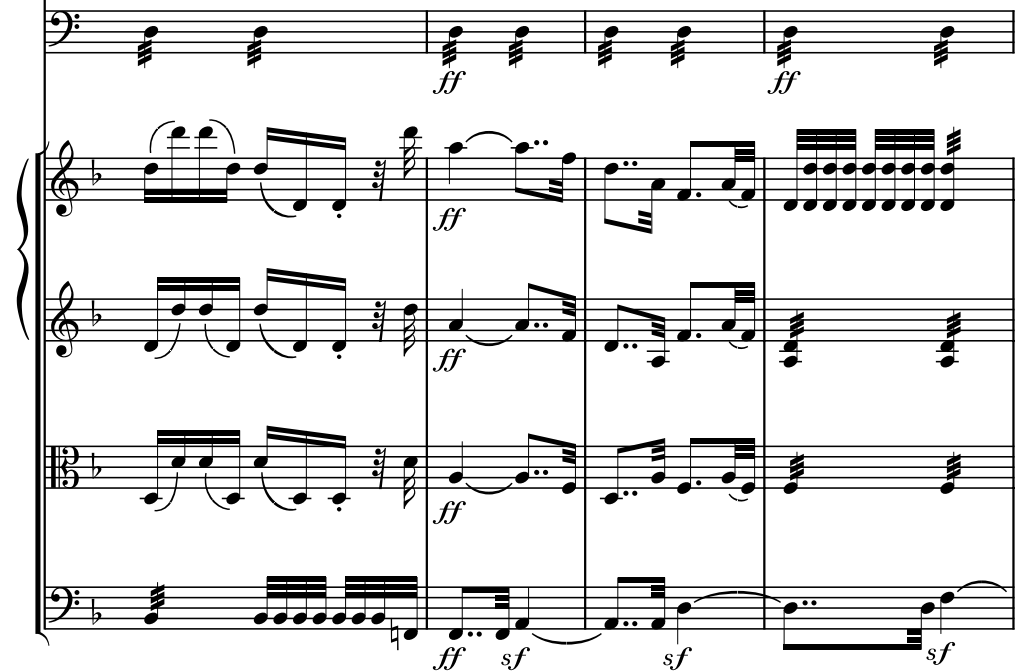
Example 3 continued

$2 \mathrm{~F}$

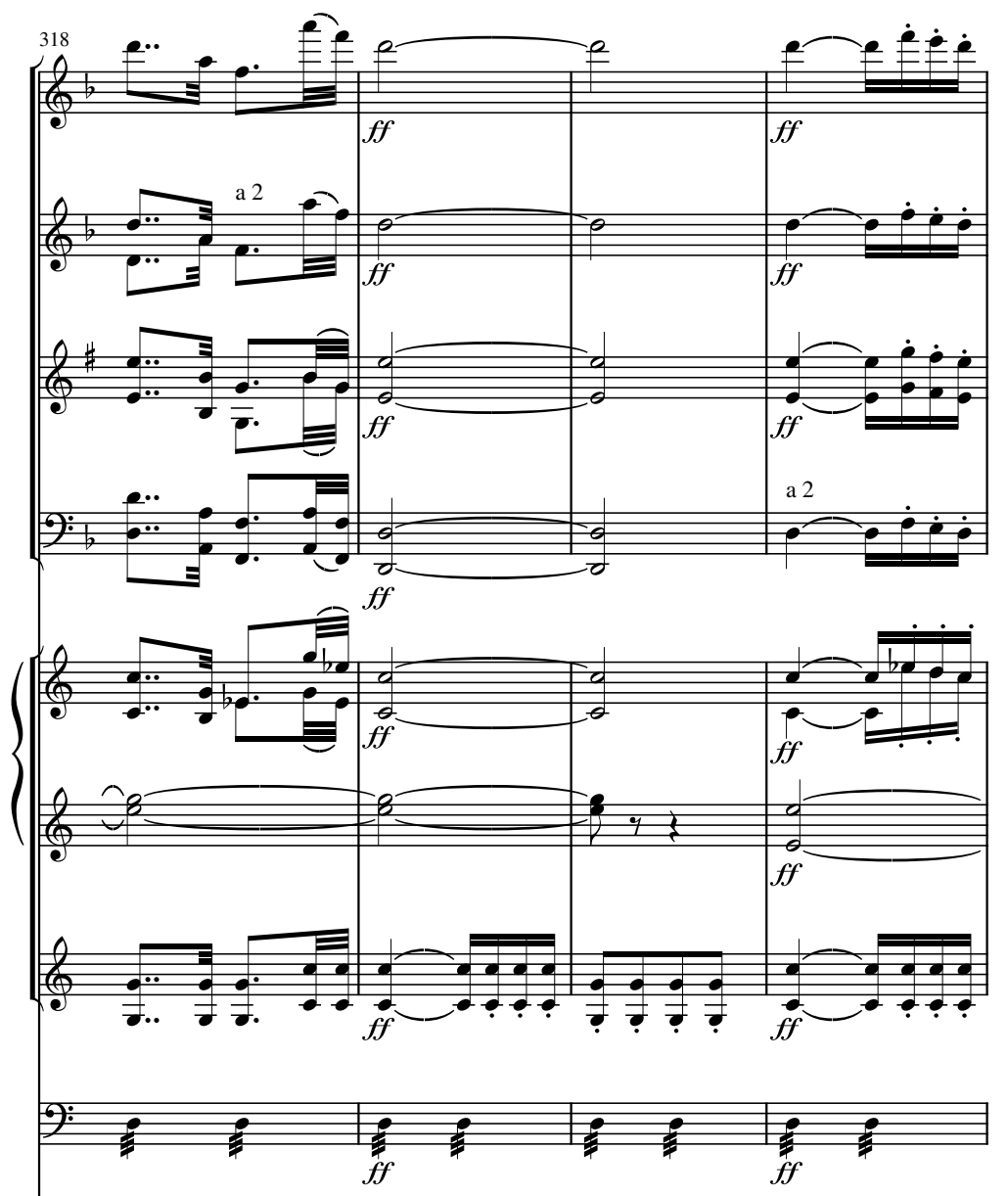

Timp.

Vl. I

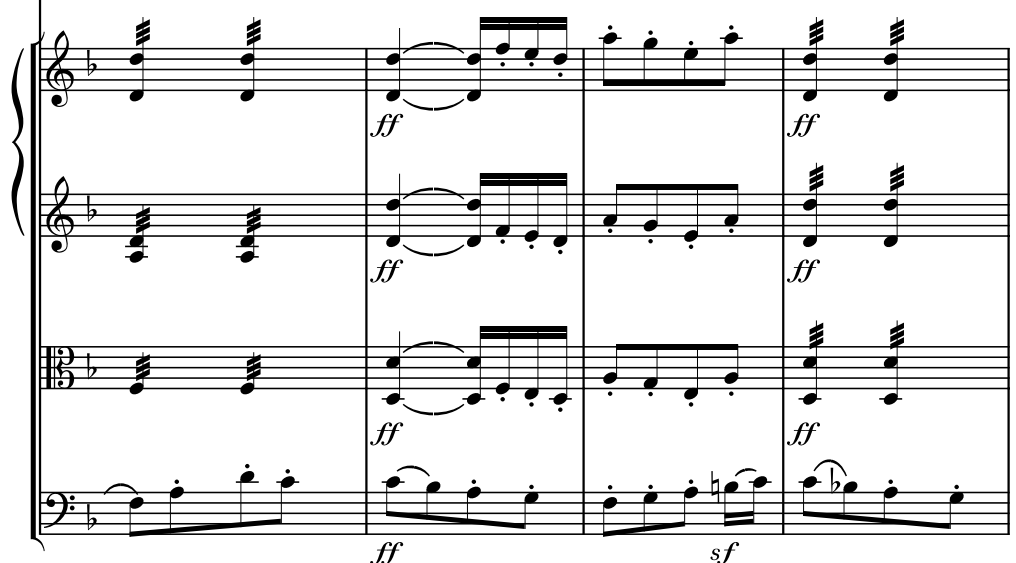


In the margin of his notes, Adorno reminds himself to refer to a page in his copy of Hegel's Aesthetics where he has scribbled the words "standing firm"; Hegel's text at this point is underlined three times:

[Art has] the mitigating effect of making the human being conscious of what, otherwise, he merely, directly is. For now the human being contemplates his impulses and inclinations; and whereas, otherwise, they carry him along without reflection, he now sees them outside himself and begins, since they confront him as something objective, to exercise his freedom in regard to them. ${ }^{127}$

For Adorno, Hegel's text suggests that art can never be a unilateral movement of fate, for its gaze always creates a bilateral distance, a "dualism . . . between itself and the beholder" that allows for critical leverage and discursive reflection. ${ }^{128}$ The recapitulation of the first movement of the Ninth Symphony performs this reflective resistance within the music itself as a sublime act; it states that in music fate is never blind. In defying the totality, the gaze of the Ninth testifies to a subject that can "exercise [its] freedom" through what Michel Foucault would call an act of "self-crafting." 129 The rogue element reinvents its footing as a bass line that stands outside the laws of voice leading in the same way that a subject can react creatively against the formal norms of society; the deviant and disjunct process of "self-crafting" that undermines the recapitulation defines the music's freedom, but this freedom exists only within the limits of the unfreedom imposed upon it. It is in this sense that the sublime awakens the sublime within the subject. ${ }^{130}$ By objectifying this form of moral resistance, the music invites the self to contemplate and re-form itself; the music "understands us."

But, of course, by prying open what is essentially a sublime monad, Adorno discovers a gaze that can only resist and not a gaze that can relate to an Other. This confrontational gaze may create the critical gap of negative dialectics but it will not open the reciprocal distance necessary for humanity to find its being. And since its critical resistance is merely a reaction to the force inflicted upon the subject, the gaze may inadvertently rehearse what it opposes and become blind in the process. In fact, Adorno's theory of mimesis demands this. "Does not music perhaps stand firm against fate precisely in becoming fate?" asks Adorno. "Is not imitation the canon of resistance? . . Does not gaining-power-over-oneself, freedom, lie only in imitation, in making-oneself similar?"131 But similar to what? After all, "standing firm" is the political

127. Quoted in Adorno, Beethoven, 205n46.

128. Ibid., 15 .

129. See Judith Butler, Giving an Account of Oneself (New York: Fordham University Press, 2005), 18-19.

130. Adorno relates this experience of "standing firm" to Kant's "dynamic sublime" in the Critique of Judgement. See Beethoven, 169.

131. Adorno, Beethoven, 169. In Dialectic of Enlightenment, 9-10, Adorno and Horkheimer describe mimesis as the imitation of what is feared in nature in order to ward off its threat. "The 
posture of the revolutionary hero. "The stoical body of the Revolution," writes Dorinda Outram, "is about the definition of an autonomous self through an . . . impermeable, controlled body"; 132 it is a monad, a non-body, an armor-plated subject that denies its senses for a hard and impervious surface, indifferent to the world it opposes. Inasmuch as "standing firm" hardens the body to become a non-body-indeed, a non-person - it is also "a mimesis of death," glazing over those "sad eyes" of Beethoven until they appear as inorganic and cold as nature herself. ${ }^{133}$

\section{The Eyes of Alterity}

Something human has died between the "sad eyes" that first arrested Adorno's attention and the resistant gaze that left his book on Beethoven incomplete. Those "sad eyes" are still waiting for Adorno to answer the question "Who am I?" because his philosophy of the particular is aligned with a metaphysics of nature which is by definition not a metaphysics of the particular at all. Perhaps it is to the philosopher's credit that he left his Beethoven project unfinished. How could the Beethoven he believed in resolve "the riddle of humanity" if all Adorno can offer is the critical gaze of dialectical negation extended into the steely vision of the Ninth Symphony? As he himself admits: "I have said that the Fifth and Ninth [Symphonies] stand firm through looking-in-the-eye. Is that still too little?"134 So is there another way to recover a gaze in Beethoven's music that is truly human, a gaze which, if returned, would bestow to the particular the ontological significance it desires?

Musical eyes are not literally objects embedded in the score as textual references or pictorial depictions, just as for Lévinas the "face" of the Other is not literally a face that can be perceived; that would merely capture the Other

sound of fate knocking at the door" in the Fifth Symphony, for example, does not "demonstrate fate"; rather, the movement that emerges from the opening measures is deployed "to cancel, preserve and elevate [aufheben] those portentous beats" (Beethoven, 166).

132. Dorinda Outram, The Body and the French Revolution: Sex, Class, and Political Culture (New Haven, CT: Yale University Press, 1989), 156 and 81.

133. Indeed, Adorno describes the hero as a pose- " the Roman as a bourgeois in fancy dress" (Beethoven, 79): it is not real, but a mask added onto the person, and in this sense the person is not a being but a role. If this is the case, then it probably has its origins in Greek thought, where, as Zizioulas suggests, the term "person" is associated with the actor's mask in Greek theater. The heroic classicism of the bourgeois borrowed from the Roman Republic similarly stems from the Roman concept of "persona" which plays a legal and social role within the collective; the freedom and identity of the Roman persona is only guaranteed by the state- the totality. In this sense, Adorno's critique of heroic Beethoven is not far from its origins in Roman thought. See Adorno, Beethoven, 79 and 190; and Zizioulas, Being as Communion, 31 and 34-35.

134. Adorno, Beethoven, 169. 
through the appropriation of the subject's vision. ${ }^{135}$ Rather, musical eyes refer to moments that cannot be assimilated, where music appears to disclose the human, as if these eyes were portals into the depth of a human being whose "delicate aura" indicates the inviolable and irreducible existence of a person. But why demand the impossible vision of a listening eye or "speculative ear"? 136 What is there to see in the "sonority" of the face?137 Precisely nothing. To return the musical glance is to see what the modern world has made invisible. In Maurice Merleau-Ponty's terms, such vision is a "voyance" that "renders present to us what is absent."138 Or as Lévinas writes: "Ethics is an optics," but, unlike the clarity of Newtonian optics, it is a "spiritual optics," "a vision without image, bereft of the synoptic and totalizing objectifying virtues of vision."139 It is visual in that it perceives the Other, but musical in that it cannot grasp the Other.

Of course, music, according to Adorno, has its own "synoptic and totalizing vision" in the Augenblick of Beethoven's heroic works. By capturing time as a spatial instant, the music mimics the eye/I of the modern subject; it masters reality through the "synchrony of representation" that seizes time in the present tense of an "I think." 140 By contrast, Beethoven's "gift of sight" ought to cancel out this synchronic gaze. ${ }^{141}$ After all, the heroic Augenblick cannot by definition be a "gift of sight" inasmuchas it seizes time as a moment, for a gift has to be given and not taken. Rather, music's donation of vision should give time for the invisible to present itself rather than seize time to

135. "The face," says Lévinas, "is not the color of the eyes, the shape of the nose, the ruddiness of the cheeks, etc." Emmanuel Lévinas, Is It Righteous to Be? Interviews with Emmanuel Lévinas, ed. Jill Robbins (Stanford, CA: Stanford University Press, 2001), 208.

136. Adorno derived the term "das spekulative Ohr" from Kierkegaard: see Theodor W. Adorno, "Schwierigkeiten," in Impromptus: Zweite Folge neu gedruckter musikalischer Aufsütze, in Musikalische Schriften IV, vol. 17 of Gesammelte Schriften, ed. Rolf Tiedemann (Frankfurt am Main: Suhrkamp, 1982), 290.

137. Lévinas, "Diachrony and Representation," 172.

138. Maurice Merleau-Ponty, "Eye and Mind," in The Merleau-Ponty Aesthetics Reader: Philosophy and Painting, ed. Galen Johnson, trans. ed. Michael B. Smith (Evanston, IL: Northwestern University Press, 1993): 132.

139. Emmanuel Lévinas, Totality and Infinity: An Essay on Exteriority, trans. Alphonso Lingis (Pittsburgh: Duquesne University Press, 1969), 23, 78, 23. Also see Lévinas's critique of "seeing" in "Diachrony and Representation," 159-68 passim.

140. Lévinas, "Diachrony and Representation," 161; italics added. In music analytical terms, this grasp of temporality is inadvertently reflected in Kevin Korsyn's identification of the Schenkerian Ursatz with the Kantian "I think": "A self is a prolongation of the 'I think'; a composition is a prolongation of an Ursatz. The organic composition, then, is a correlate of Kant's cognitive subject; the Ursatz is the transcendental consciousness of the piece, its 'I think.' " Given that Schenker's inspiration for the Ursatz stems from his work on the music of the heroic Beethoven, the analogy is fitting. See Korsyn, "Schenker and Kantian Epistemology," Theoria 3 (1988): 35. On Schenker's Ursatz and the heroic Beethoven, see Burnham, Beethoven Hero, 89-102.

141. Adorno, Beethoven, 164. 
re-present the unseen in its retinal grasp. Thus the paradox of seeing-whatis-heard is designed to contradict the instantaneous instrumentality of Enlightenment observation. ${ }^{142}$ Instead of a Vor-stellen that positions an object in front of the subject's gaze, seeing what is heard (the unseen) allows an auratic Other to "show itself [as other] by giving itself." 143 The ethical task of this donation, then, is to break the visual economy of modern existence; music's gift is a counter-moment to the contractual circle that literally contracts time into a formal instant. ${ }^{144}$ It is a moment within a moment, an "Ohrenblick" within the Augenblick, an inner fracture within the totality, resulting in what Lévinas calls a diachronic coexistence in which the time of the "I" is suspended by the time of the "Other." Or, to use Benjamin's definition of aura, it is a "strange weave of space and time" that requires the donation of a certain distance and duration to host an-Other dimension. ${ }^{145}$

Thus Beethoven's "gift of sight" is literally a gift; it gives time for an Other to give itself to be seen. From this perspective, music's intrinsic temporality is redeemed as a site/sight for a phenomenology of donation. It is only in this way that music can be said to "understand us," enabling the I to see itself in the eyes of an Other. But what kind of music has this "gift of sight"? I suggest that there are at least three mimetic qualities congruent with Adorno's philosophy which music must convey in order for its temporal gaze to be human.

First, if "the human is its gaze," then the music's mimetic impulse ought to be human. Beethoven's music must therefore disclose an-Other human being whose very gaze questions the "Da" of my "Dasein" (there-being), to borrow Lévinas's play on Martin Heidegger's ontological concept of "being-in-the

142. On Enlightenment observation, see, for example, Martin Jay, Downcast Eyes: The Denigration of Vision in Twentieth-Century French Thought (Berkeley: University of California Press, 1993), 21-147.

143. Jean-Luc Marion, Being Given: Toward a Phenomenology of Givenness, trans. Jeffrey L. Kosky (Stanford, CA: Stanford University Press, 2002). This phrase is repeated several times on pages 323-24 with minor changes; the quotation here is a composite one.

144. Or as Jacques Derrida puts it, a gift can take place only in an "instant of effraction (of the temporal circle)"; see Derrida, Given Time: I. Counterfeit Money, trans. Peggy Kamuf (Chicago: University of Chicago Press, 1992), 9. Derrida's theoretical position, in giving insight into the essence of gift, is also purely unilateral; it is unconditional, without reciprocity, and therefore cannot circulate. This extreme asymmetry is problematic in that it severs any genuine relation. Derrida is probably correct in criticizing Marcel Mauss's contradictory notions of "gift exchange" to safeguard the gift from circulating within an economy (Given Time, 24-33 passim), but his abstract withdrawal of the gift from any reciprocity is not the only way to preserve its unconditional nature. The challenge is to think of reciprocation, or at least, the relation mediated by the instant of the gift, in ways that are alterior to the circle of modern exchange. For a critique and extension of Derrida's notion of gift, see Book 2 of Marion's Being Given.

145. Walter Benjamin, "Little History of Photography," trans. Edmund Jephcott and Kingsley Shorter, in Selected Writings, 4 vols., ed. Marcus Bullock et al., trans. Rodney Livingstone et al. (Cambridge MA: Harvard University Press, 1996-2003), 2:518. Also see idem, "The Work of Art in the Age of Mechanical Reproduction," in Illuminations, 216; and idem, "On Some Motifs in Baudelaire," 184. 
world"; 146 it re-positions our right to be (there). What should not appear is some kind of human substitute devoid of flesh and blood such as one of Adorno's incorporeal forms (an apparition, Eurydice) or a twinkle of inanimate nature (a star) that merely replays, however negatively, the ontological premise of Platonic or Aristotelian thought. In contrast, a music that is anthropomorphically grounded will inhabit the spaces of the human body, mimicking its motions and emotions. After all, the body particularizes; it constitutes the human being, defining each person as unique in relation to another in space and time; only then can its "this-ness" displace the "Da" of my "Dasein." "147 Indeed, if Merleau-Ponty is correct, it is not our minds that look through our bodies, as if our eye-contact with music were simply a meeting of minds; it is a somatic intertwining. ${ }^{148} \mathrm{Or}$, as Lévinas writes, "The visible caresses the eye. One sees and one hears like one touches."149 The gaze of humanity, then, is a bodily relation, a vulnerable and somatic form of knowledge between irreplaceable particulars. ${ }^{150}$

Second, the body must breathe. This is not only because breath distinguishes the body from mere matter, particularizing the dust of nature from which the human being is formed, but also because the fragility of its motionthe drawing-in and breathing-out of air-locates life in the here and now of space and time, rather than attributing it to some eternal substance or timeless form. Breathing is the persisting sound of the transient, the movement of time within the given-ness of time. It is life, not death; fragile, of course, but not fatal. The breathing body, in fact, is not far from Adorno's description of art's mimetic impulse as the sublimation of a "physiologically primordial form of spirit" and it resonates with "the etymological connotation of the word 'aura,' " which means "breath" or "breeze" in both Greek and Latin. ${ }^{151}$ Art ought to restore the breathing body to modern knowledge, not least in music

146. This pun is one of Lévinas's recurring phrases: see, for example, Lévinas's "Diachrony and Representation," 169; and his "Philosophy and Transcendence," in Alterity and Transcendence, 23.

147. See Gunton, The One, the Three and the Many, 48-49.

148. See Maurice Merleau-Ponty, "The Intertwining-the Chiasm," in The Visible and the Invisible, ed. Claude Lefort, trans. Alphonso Lingis (Evanston, IL: Northwestern University Press, 1968), 130-55.

149. Lévinas, "Language and Proximity," in Collected Philosophical Papers, trans. Alphonso Lingis (Pittsburgh: Duquesne University Press, 1998), 118.

150. Arnie Cox, in "The Mimetic Hypothesis and Embodied Musical Meaning" Musicae Scientiae 5 (2001): 195-212, explains that we experience music through "mimetic participation" (196). When we perceive a performance by someone else, music fires the same motor neurons in us as in the performer; it is as if we were performing that action ourselves. Thus hearing is not simply a mental process but a somatic one often accompanied by a covert movement of vocal muscles ("subvocalization"). Such physical gestures suggest that musical understanding always occurs in relation with some-body. Adorno makes a similar claim: "To imagine music is always to sing it inwardly: imagining it is inseparable from the physical sensation of the vocal cords" (Beethoven, $173)$.

151. Adorno, Aesthetic Theory, 113; and Hansen, "Benjamin's Aura," 351. 
whose very phrasing is breathing itself. But this knowledge, for Adorno, is not predicated on just any type of breathing body, but one that is inextricably linked to the "physical suffering" of human existence, a suffering that demands nothing less than a "resurrection of the flesh" to reanimate the material and nonidentical qualities that modern thought suppresses. ${ }^{152}$ Music's breath must therefore embrace suffering, an expression of pain through which "art defends itself against ... its law of form" states Adorno; the "formal law of freedom" has its monadic powers undone by "the suffering countenance of artworks." But, as Adorno cautions, "they turn this countenance only on those who return its gaze." ${ }^{53}$ Thus the coldness of modern reason must be countered by a gaze that discloses the physiological suffering of a human being whose hope of resurrection affirms its desire to be-indeed, its desire to breathe.

Finally, the music must imitate love (agape), the condition for an unconditional gift. While the body and its breath particularizes, it is love that brings particulars into relation. Indeed, the problem with love, as far as the stoical coldness of rationalist ethics is concerned, is precisely its relational particularity; "compassion is always inadequate," comment Adorno and Horkheimer, because it only attends to some and not all; 154 instead of transforming the basis of social injustice, its fortuitous activity merely "confirms the rule of inhumanity by the exception it practices." 155 Hence for Adorno, love, which is "one of the greatest impulses of Christianity," has exhausted its historical potential; a post-Christian society is one in which love has failed "to eradicate the coldness that permeates everything ... because it did not reach into the societal order that produces and reproduces that coldness." 156 Of course, the particular failure of love is inscribed in its very nature as a relational act; the reciprocal gaze is always specific and not some panoptic vision installed above society. ${ }^{157}$ Thus by modern standards, love is radically unfair, subverting the equality of reason by creating an intricate and contingent network of

152. Theodor W. Adorno, Negative Dialectics, trans. E. B. Ashton (London: Routledge, 1973), 202 and 401.

153. Adorno, Aesthetic Theory, 110-11. Suffering is the only authentic expression of artworks for Adorno "just as the expression of living creatures is that of pain" (ibid., 110); hence Beethoven's expression always "waits with sad eyes for us to answer" (Beethoven, xi). For this countenance to see us, the expression of suffering is not simply a copy of the pain of an individual subject as if this were merely a reification of suffering: as the expression of an-Other, suffering has to be the objective "expression of the work itself" (Aesthetic Theory, 111).

154. Adorno and Horkheimer, Dialectic of Enlightenment, 103.

155. Ibid., 102.

156. Adorno, "Education After Auschwitz," 202.

157. Love's political failure has a long history, as David Nirenberg notes in "The Politics of Love and Its Enemies," Critical Inquiry 33 (2007): 573-605; in fact, for Nirenberg, the politics of love, like the politics of freedom, merely reproduces the exclusion it wants to overcome. However, a loving politics may be asking too much of politics, given that sovereignty, if Agamben is correct, is founded on exclusion. And, of course, love is itself scandalously exclusive in its preoccupation with unique relationships. Although such exclusion is radically different from that of a 
asymmetrical and surprising relationships, each of which is unique. So despiteor even because of - its fortuitous nature, compassion is also the antithesis of coldness for Adorno. As the philosopher writes, people "are thoroughly cold [because] deep within themselves they must deny the possibility of love, must withdraw their love from other people initially, before it can even unfold."158 As the antithesis of coldness, compassion is the only cure in a society in which knowledge is divorced from love: hence "to rescue is to love things" states Adorno. And to "love things," explains Bernstein, is to know things with the kind of "contingency, sensuousness, and vulnerability" that modern knowledge distrusts as blind, sentimental, and irrational. ${ }^{159}$ There has to be an "affective investment" in the object, what Adorno calls "the moment called "cathexis' in psychology," in which knowledge becomes inextricably personal, discovering the "who" and not simply the "what" of the particular. "[T]he joining of cathexis and mimetic reaction form[s] the full pull and tug of the object," explains Bernstein, "its cognitive mattering," its freedom. ${ }^{160}$ At the most basic level, this form of knowledge is somatic; it means "taking your pain ... as equivalent to my own"; in attending to the sensuous particular, "compassion immediately figures the integrity of the body." 161 Love is therefore inextricably somatic, yet, because it is relational and not material, love persists beyond the body. It is a commitment that never fails to be given; 162 "this devotion," this "relation to the other as other," says Lévinas, "is time" because it gives time without limit. ${ }^{163}$ Love is eternal, then, only in the sense that it is infinitely patient and infinitely giving. ${ }^{164}$ This is why Zizioulas champions agape as the replacement for substance (or nature) in the ontology of the

discriminatory politics, it is easy to slip from one to the other when power is at stake. Nirenberg's history of love's political failure is as much a history of its use and abuse. What I want to develop here is not a politics of love but a particular mode of love (agape) that relates to alterity in giving time for the other.

158. Adorno, "Education After Auschwitz," 200-201.

159. Bernstein, Adorno: Disenchantment and Ethics, 406

160. Ibid., 401.

161. Ibid., 406 and 408.

162. As Saint Paul famously writes, love "remains" and "never fails" (I Cor. 13:8 and 13 [NIV]).

163. Lévinas, "Diachrony and Representation," 173.

164. In fact, for Adorno, "the joining of cathexis and mimetic reaction" forms the basis for an authentic experience of art; "immersed in [the] immanent movement" of music's sensuous rationality, the subject is "recomposed by the ear in accordance with [the artwork's] own logic." Such listening "demands work and effort ... strength of attention and memory, ... . [it] demands, in fact, love." Adorno is articulating a way of hearing the detail within the whole that "discloses the richness of the detail on which it dwells rather than hurrying past it to the whole with an anxious impatience." True listening, like love, is a giving of time in terms of an infinite patience for the object's self-disclosure. The citations are from Adorno, "Presuppositions," in Notes to Literature 2:97; idem, "Schwierigkeiten," 289; and idem, "Schöne Stellen," in Musikalische Schriften V, vol. 18 of Gesammelte Schriften, ed. Rolf Tiedemann (Frankfurt am Main: Suhrkamp, 1984), 699. Also see Nicholsen, Exact Imagination, esp. 15-58; the translations are from 5 and 18-19. 
person. ${ }^{165}$ The metaphysics of the transient particular finds its temporal permanence in an unbreakable bond; "outside the communion of love," writes Zizioulas, "the person loses its uniqueness and becomes a being like other beings, a 'thing' without absolute 'identity' and 'name,' without a face." 166 Love is "the condition of the very possibility of uniqueness."167

Thus "the delicate aura of the other" does not give access to some eternal essence of humanity - to its soul, nature, mind, or spirit-but opens a temporal window into the transient, breathing body of a human being who secures her unique existence in being loved. These indicators of alterity-body, breath, love-are not arbitrary signs: they parallel the three elements that Naomi Cumming identifies as the way in which subjectivity presents itself in music - gesture (shape), voice (timbre), and will (tonal motion). ${ }^{168}$ However, as the Other of the subject these indicators are anterior to the ego's selfpresentation: The Other is not gesture, but merely a body; it is not voice, but its breath; it is not will but love, a relation prior to the volitional act. ${ }^{169}$ Alterity in music is therefore a suspension of the subject, a dis-articulation of its gestural, vocal, and volitional display. Of course, it is not that there is no longer shape, timbre, or motion, since without these qualities the music will cease to be music. But in the same way that seeing the invisible is, in Lévinas's words, a vision of a "being-without-insistence ... [a] being-on-tiptoe ... without name ... stripped bare of all attributes," so hearing the inaudible is the sound of a being prior to the subject's self-presence. ${ }^{170}$ But the question remains: where in Beethoven's music can such a gaze be returned?

\section{The Body and Memory}

Hans-Günter Ottenberg suggests that some of Beethoven's music recalls the Empfindsamkeit of C. P. E. Bach. ${ }^{171}$ The term "Empfindung" in the eighteenth century carried connotations of both sensory perception and emotional sensibility, and Empfindsamkeit was the manner in which the sentient and sen-

165. See Zizioulas, "On Being a Person," 45-46.

166. Ibid., 42; and idem, Being as Communion, 49. The relationship between nature (body) and love is summarized by Zizioulas in terms of biological and ecclesial existence; see Being as Communion, 49-65.

167. Lévinas, "Diachrony and Representation," 168.

168. See Naomi Cumming, "The Subjectivities of 'Erbarme Dich,'” Music Analysis, 16 (1997): 5-44. For a full account on Cumming's philosophical position see her The Sonic Self: Musical Subjectivity and Signification (Bloomington and Indianapolis: Indiana University Press, 2000).

169. On love as a restraining of the will, see Butler, Giving an Account of Oneself, 106-7.

170. Emmanuel Lévinas, "From the One to the Other: Transcendence and Time," in Entre nous, 143).

171. Hans-Günter Ottenberg, Carl Philipp Emanuel Bach, trans. P. J. Whitmore (Oxford: Oxford University Press, 1987), 192-98. 
timental body articulated its musical feelings. In an attempt to simulate this psychosomatic flux, C. P. E. Bach disrupts the regular rhythms of the High Baroque with a music that moves in fits and starts. The formal surface breaks down under the emotive pressure, and the body obtrudes through the gaps. Indeed, his scores for clavichord are somatic scripts; they are meticulously notated with tactile signs-Bebung, Tragen, staccato, slurs - that define the particular "touch" required to arouse the humors and tingle the nerve fibers, creating a musical sensorium in which the audience can vibrate sympathetically together. ${ }^{172}$

The expressive indications alone in Beethoven's late works are enough to suggest a return to this pre-heroic aesthetic - "mit inniger Empfindung" or "Appassionato e con molto sentimento" or simply "molto espressivo."173 Such music divests itself of the stoical body of the revolution, with its cold, impermeable surfaces. This unflinching body gives way to the sentient as feeling disrupts form. And as with C. P. E. Bach, it is through notation that the body in late Beethoven presses its emotions against the surface; it protrudes as densely populated markings of touch and expression that suddenly crowd the score with emotional ruptures. At such points the body becomes thematic; the human discloses itself.

The very last chord of the Cavatina in the B-flat-major String Quartet, Op. 130, is an example of such a disclosure (see Ex. 4). It is just a tonic chord, of course, nothing more than what would be expected from a concluding sonority. As a tacit function of closure, it hardly draws attention to itself, and yet visually what should be a simple notational act-a block of half notestakes on an expressive density that clutters the final measure with minute performance indications. These are physiological markings. There are no less then four dynamic signs crammed within one measure (m. 66)-piano, crescendo, diminuendo, pianissimo. And in place of a final half note, there are four eighth notes tied together in order to quantify the exact amount of expressive shading required on each division of the beat. ${ }^{174}$ This is a written-out breath-but not just any breath; Beethoven demands of his notation a specific psychosomatic motion of intense emotive force, one that disrupts the respiratory rhythms of the lungs. The breath is asymmetrical; first a sharp intake of air (crescendo), then a sudden suspension (piano), followed by another gasp

172. See Chua, Absolute Music, 114-25.

173. See the Piano Sonatas, Op. 106 (third movement), Op. 109 (finale), and Op. 110 (first movement), and the final section of the Heiliger Dankgesang in the A-minor Quartet, Op. 132; italics added.

174. Emil Platen discusses the notation of this chord and other examples of what he calls "differenzierte Lautstärken-Rhythmisierung" in the late quartets in "Zeitgenössische Hinweise zur Aufführungspraxis der letzten Streichquartette Beethovens," in Beiträge '76-78: BeethovenKolloquium 1977: Dokumentation und Aufführungspraxis, ed. Rudolf Klein (Kassel, Bärenreiter, 1978), 105. Also see David B. Levy, “'Ma però beschleunigend': Notation and Meaning in Ops. 133/134," Beethoven Forum 14 (2007): 129-49. 
Example 4 Beethoven, String Quartet in B-flat Major, Op. 130, Cavatina, mm. 65-66

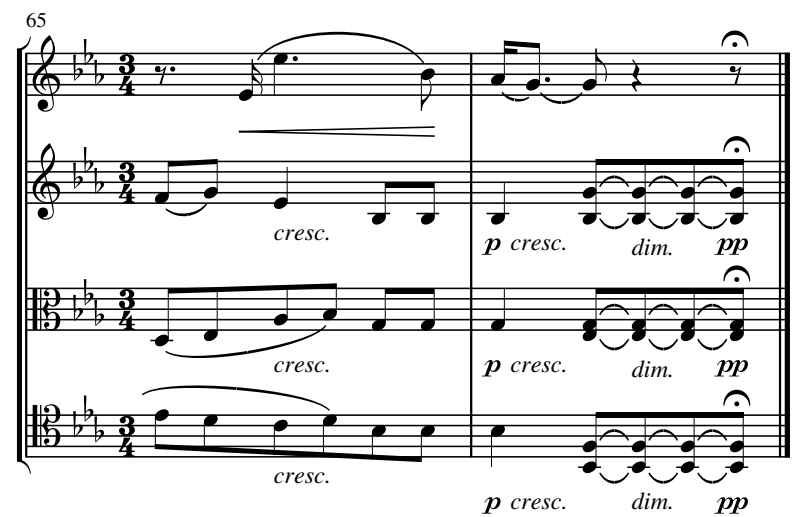

(crescendo) before allowing the rib-cage to sink back (diminuendo) to a point of rest (pianissimo, pause). On the face of it, this is a common chord, but the emotional intensity that shapes the sonority remolds the facial surface, creating a physiognomy that pierces the cadence with a gaze from deep within.

The depth of these eyes literally derive from the interior of the music, for the final "breath" of the "Cavatina" is itself a consequence of severe respiratory symptoms in the middle of the movement where a sudden change of mood and mode takes the music into another world (Ex. 5).

Formally, it is an insertion, a foreign body that distances itself from its lyrical surroundings. Perhaps this is because it is a quotation that telescopes the psychological breakdown of the Arioso dolente in the A-flat-major Piano Sonata, Op. 110, written some four years earlier. Not only does Beethoven recall the breathless gestures of the Arioso (mm. 116-131), but he selects the unmistakable harmonic twist of the opening recitative and lays it down as the harmonic pulsations for the central section of the Cavatina (Ex. 6). ${ }^{175}$ What surfaces, then, at the center of the Cavatina is the fragmentary recollection of a previous work that vanishes as suddenly as it appears. It might be construed as one of Adorno's fleeting apparitions, an ephemeral glimmer that fades in the spaces vacated by the subject. Indeed, Wolfgang Osthoff suggest that this central section may refer to "ombra" scenes that haunt certain subgenres of cavatina. ${ }^{176}$

175. See also Daniel K. L. Chua, The "Galitzin" Quartets of Beethoven: Opp. 127, 132, 130 (Princeton, NJ: Princeton University Press, 1995), 193-98. As we shall see, these breathless gestures occur in other late works, but the Arioso and Cavatina provide the most extended and heightened examples, and are therefore the most closely related in detail.

176. Wolfgang Osthoff, "Mozarts Cavatinen und ihre Tradition," in Helmut Osthoff zu seinem siebzigsten Geburtstag, ed. Ursula Aarburg and Peter Cahn, 139-77 (Tutzing: Hans Schneider, 1969). Lewis Lockwood in Beethoven: Studies in the Creative Process (Cambridge, MA: Harvard University Press, 1992), 210, uses this idea as a catalyst for some thoughts on the Cavatina. 
Example 5 Beethoven, String Quartet in B-flat Major, Op. 130, Cavatina, mm. 40-48
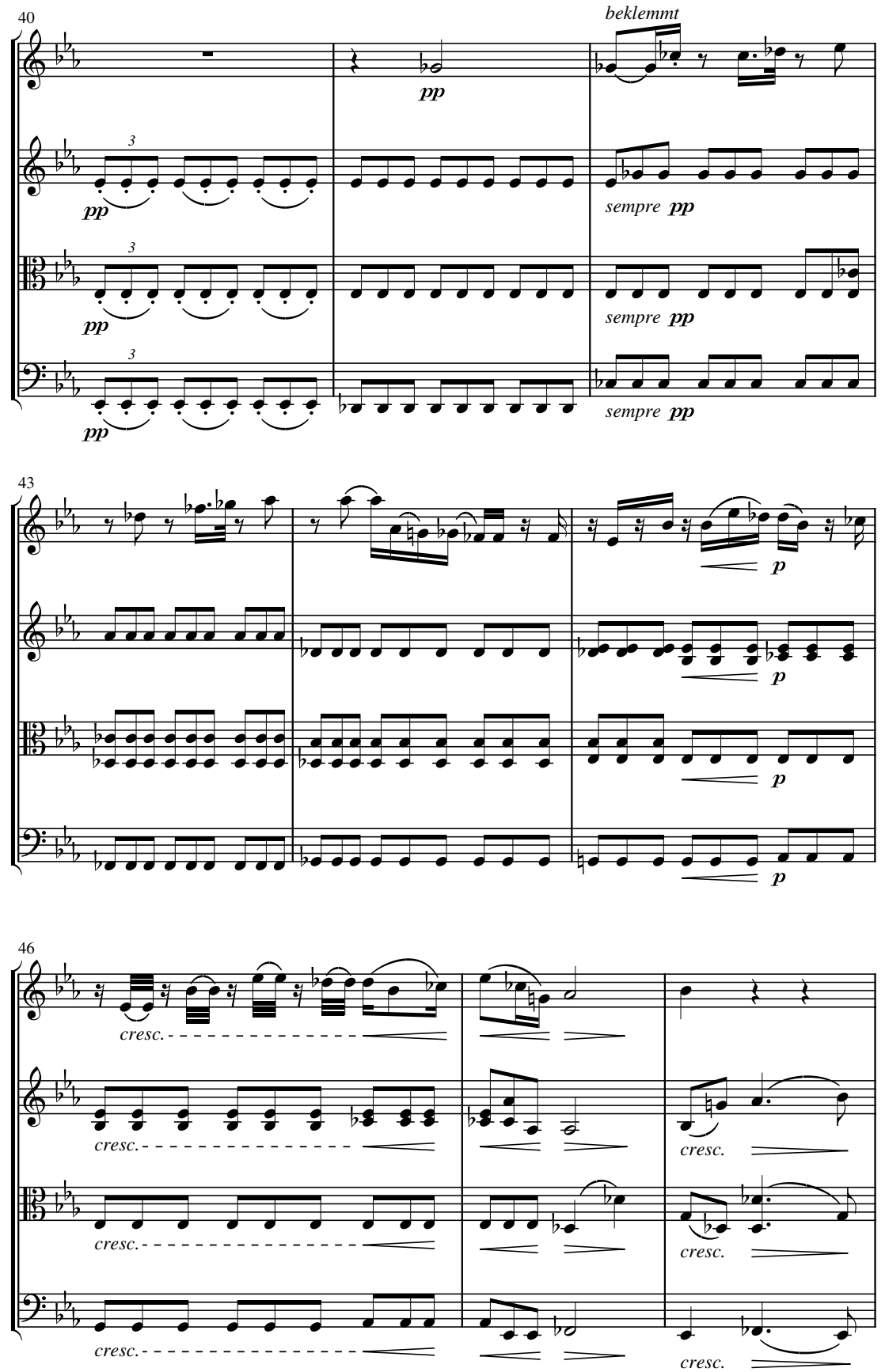
Example 6 The harmonic quotation of Beethoven's Piano Sonata, Op. 110, third movement, in the Cavatina, mm. 42-46

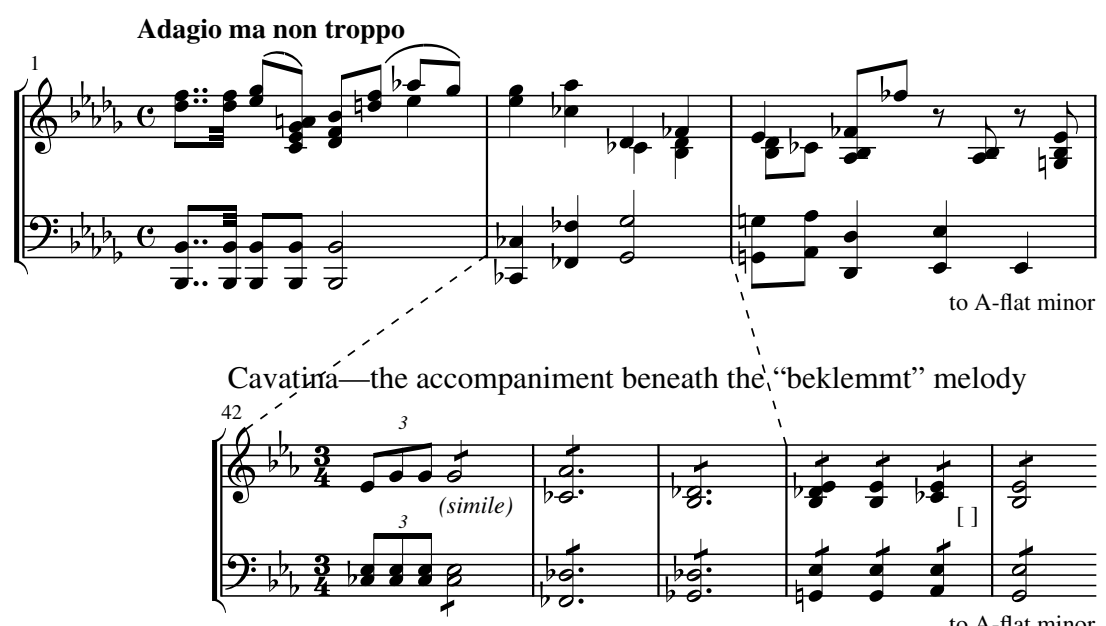

to A-flat minor

But this quotation, because of its sheer physicality, is less a ghost than a memory in the Proustian sense. In $A$ la recherche du temps perdu, to remember is not some phantom operation of the mind. Rather time lost is retrieved in the "the composite memory of [the body's] ribs, its knees, its shoulder blades"; it is in "the position of various limbs" that the forgotten spaces and objects of "far-distant days" are re-coordinated for Proust. ${ }^{177}$ So despite its fleeting appearance, the quotation in the Cavatina is strangely embodied. It is as if the respiratory figures are located in the throat, ribs, and guts of the music's anthropomorphic movements, rendering the past painfully present. The "body," as Merleau-Ponty puts it, "takes possession of time." 178 This means that in the temporal disruption of the Cavatina, there is a mimetic encounter with a person and not some spectral recollection or generalized emotive state commonly

177. Marcel Proust, Swann's Way, part 1 of In Search of Lost Time, trans. C. K. Scott Moncrieff and Terence Kilmartin, rev. D. J. Enright (London: Vintage, 1996), 4. Henri Bergson's exploration of time has often been compared to Proust's. Memory, for Bergson, is also a bodily habit; in Matter and Memory (1896), trans. Nancy Margaret Paul and W. Scott Palmer (New York: Zone Books, 2004), 153, he writes: "It is from the present that the appeal to which memory responds comes, and it is from the sensori-motor elements of present action that a memory borrows the warmth which gives it life." This is actually borne out by Beethoven's own memory of the Cavatina. According to Karl Holz, "even the remembered feelings aroused by this piece always cost him new tears" (italics added); see Wilhelm von Lenz, Beethoven: Eine Kunststudie, 6 parts in 5 vols. (Cassel: Balde; and Hamburg: Hoffmann \& Campe, 1855-60), vol. 5, pt. 4, p. 217; and Thayer, Thayer's Life of Beethoven, 975.

178. Maurice Merleau-Ponty, Phenomenology of Perception, trans. Colin Smith (London: Routledge and Kegan Paul, 1962), 240. 
ascribed to music's abstract affections and topical references: "time [remembered] is someone" or rather somebody - a unique, sensuous particular. ${ }^{179}$ To register this body is to give it time.

Moreover, this memory is Proustian in that the material it recollects is not a deliberate imitation of Opus 110 as if it were a conscious attempt to master the past; rather it is an opaque resemblance that re-assembles the fragmentary data as a seemingly involuntary act of the memory. What surfaces in the Cavatina are merely transient elements of Opus 110, but they are now so intense that they seem preserved in the present. A motivic shape, a harmonic progression, a gesture, an accompanimental figure ${ }^{180}$ — these tiny details are reconfigured from the original sonata. But the harmonic twist into the remote realm of C-flat major (the flattened submediant), endows the material with an auratic "appearance [Erscheinung] of a distance"181_the glow of a lost moment of happiness - turning these opaque resemblances almost translucent; in effect, a dream-like aura radiates through the somatic suffering the Cavatina enacts, rendering the disfigured body strangely beautiful. This somebody, in other words, is not only physically there as an unsightly disturbance disrupting our time: its beauty glows at us. Or as Benjamin would put it: the music suddenly "lifts up its eyes." "To perceive the aura of an object we look at," he writes, "means to invest it with the ability to look at us in return. This experience corresponds to the data of [Proust's] mémoire involontaire." 182 What confronts us, then, in the Cavatina is a body and its aura: a suffering that looks at us.

"Beklemmt" [constricted, uneasy, anguished] is Beethoven's marking for these six measures of breathless stuttering. Exactly what is said is hardly relevant since the first violin appears barely able to speak; it is choking on its own words. The lyricism that opens the movement is reduced to a kind of wheezing, as if the diaphragm, which regulates the long phrases in the outer sections of the Cavatina, has collapsed into spasmodic twitching. The delayed phrases and reiterated gestures indicate that there is a kind of stickiness at the back of the throat that prevents the notes from articulating themselves on time; they are syncopated, disrupted by the tiny gasps of air that become increasingly breathless (from eighth-note to sixteenth-note rests), so that what is said comes out as half-torn sentences or just as isolated, stuttering syllables. These para-linguistic markings are the superfluous articulations inscribed in what Lévinas would call the "sensorial content" of suffering, an excess signification whose "uselessness" underlines the intrinsic "nothingness" of such affliction:

179. Mauro Carbone, The Thinking of the Sensible: Merleau-Ponty's A-Philosophy (Evanston, IL: Northwestern University Press, 2004), 4.

180. The central section of the Cavatina is assembled from the following measures of the third movement of Opus 110: mm. 1-3 (harmony), mm. 7-8 and 115 (accompaniment), and mm. 116-131 (motifs and gesture).

181. Benjamin "On Some Motifs in Baudelaire," 184; translation modified.

182. Ibid., $196 \mathrm{n} 17$ and 184. 
the pain is "for nothing." This "refusal of meaning" thrusts itself forward in the Cavatina as the physiology of a dysfunctional body that can no longer coordinate itself, ${ }^{183}$ as if its suffering were unutterable, leaving the muteness of the body to "speak."

What is "said," then, appears immediate in its palpability, evoking a sensuous impact that demands of us an affective investment in its pain. And yet this sensory appeal is simultaneously distanced by the formal disruption of the beklemmt section; the remote thematic and harmonic material is a shock, preventing the pain of the Other from being mastered by the sympathetic vibrations of Empfindsamkeit or the logic of some formal law. This is because the material has no cause; there is no motivic source or tonal sense to this seemingly accidental appearance. So instead of in-forming the structure, the material de-forms it, evoking the incomprehension that Lévinas demands if the Other is to be preserved rather than possessed. Indeed, pain for Lévinas is the very way in which alterity disrupts form; it opposes the "synthesis of the Kantian 'I think,' " he states, preventing the subject's grasp of the whole. ${ }^{184}$ Thus suddenly, in the disjunction of the Cavatina, we are confronted by the suffering of an unknown gaze that "wants to be gazed upon," precisely because it resists the grasp of the modern eye. This, however, is not the gaze of one "standing firm," as in the Ninth Symphony, but of one who is broken, expressing a vulnerability which is as foreign to the modern subject as the beklemmt section is to the rest of the Cavatina. Indeed, if the steely vision of the Ninth merely confirms the form by resisting the necessity of the recapitulation, the eyes of the Cavatina by their very weakness disarm the structure rendering its content contingent.

Breathing, sentient, broken: the eyes of the Cavatina bear the marks of alterity. But in order for this gaze to be human, this seeing and giving cannot be a unilateral act but a relational one: it takes two to be human. So if Beethoven's "music has the gift of sight," as Adorno claims, if "the human is its gaze," then the Cavatina has to be explored from two perspectives: from the Self's relation to the Other, and from the Other's relation to the Self.

\section{The Form of the Other}

The Self's relation to the Other is necessarily a mixture of hostility and hospitality. To host a stranger, as Derrida points out, is always an aporetic act, caught in the tension between mastery and altruism: it is selfless in that it receives the Other without question, but domineering in that it requires borders to demarcate the play of power between the self and the Other. ${ }^{185}$ In aesthetic

183. See Lévinas, "Useless Suffering," in Entre nous, 91-93.

184. Ibid., 91.

185. See Jacques Derrida, Of Hospitality: Anne Dufourmantelle Invites Jacques Derrida to Respond, trans. Rachel Bowlby (Stanford, CA: Stanford University Press, 2000). 
terms, such mastery of content is form; any altruism toward the Other will necessarily create a structural tension. So if the somatic gaze at the center of the Cavatina questions the "Da" of our "Dasein," then the formal relationship between the outer and inner sections of the movement ought to model the position $(D a)$ of our being (Sein) in the face of alterity. On a cursory level, nothing could be simpler than the $\mathrm{A}^{\mathrm{l}} \mathrm{BA}^{2}$ arrangement of the Cavatina; the formal contract between the outer A sections holds the structure in symmetry, like the pillars of an arch (Fig. 1). Indeed, nothing could be more generic than this ternary pattern. It functions, as with most forms, as a basic concept (Begriff), designed to grasp (greifen) the increasingly mixed messages of the musical material since the late eighteenth century by cutting across generic and taxonomic distinctions and by subsuming musical particulars under some higher order. ${ }^{186}$ In this sense, form is the aesthetic equivalent of Lévinas's "synchrony of representation" that seizes the material as something to be gazed at in an instant. The ternary structure grasps the music as a spatial present; it takes "control of the now [ main-tenant]" by appropriating what is "at hand [ main],"187 fashioning the form as "the beautiful in music." 188 But the formal law, as we have noted, is always hidden by the purity of its rational abstraction; its "beauty," as Adorno writes, "is sullied by the manipulative, 'composed' violence of its exemplary works." It is for this reason that Adorno speaks of formal coercion as the terror "peer[ing] out of the eyes of beauty."189

In the Cavatina, however, the disruption of form opens the eye of an Other as a counterfigure to that terror. The gaze strips the music of its formal beauty, disabling the symmetrical function of the outer sections by grasping the form as the music circles from $\mathrm{A}^{1}$ back to $\mathrm{A}^{2}$. In Lévinas's terms, there is an inner fracture within the synchrony of form that results in a "deformalization of time." 190 The music is out of time, or more precisely, in an-other time, creating a moment of temporal differentiation-a "diachrony."191 This is because the

186. "Begriff" is derived from the verb "greifen" (to grasp), as is the word "griff" (grasped) and "Griff" (the grasp). On form and concept see Spitzer, Music as Philosophy, 231. Although non-identity in Adorno's thought is often taken to be that which eludes the concept (a nonconceptual remainder), it is important to distinguish in Adorno's thought between the "simple concept" and the "thick concept," as J. M. Bernstein reminds us. Whereas the former suppresses the nonidentical with its logical abstractions, the latter involves a material dimension (the materiality of the Other) which Adorno wants to inscribe in thought. The material, of course, is precisely what we have been trying to "conceive" in this analysis. See Bernstein, Adorno: Disenchantment and Ethics, 263-329.

187. Lévinas, "Nonintentional Consciousness," in Entre nous, 130; and idem, "The Philosophical Determination of the Idea of Culture," in Entre nous, 181 and 180.

188. Eduard Hanslick, The Beautiful in Music, ed. Moris Weitz, trans. Gustav Cohen (New York: Liberal Arts Press, 1957); Hanslick's description of music as the "self-subsistent form of the beautiful" (9) derives form Kant's third critique.

189. Adorno, Aesthetic Theory, 48 and 52.

190. Lévinas, "Diachrony and Representation," 175; italics added.

191. Lévinas's use of the term "diachrony" differs from common usage in Saussurean linguistics where it describes the historical development of an object. For Lévinas, "diachrony" stands in 


\section{"Formal symmetrical grasp"}

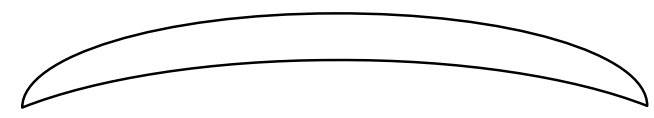

$\begin{array}{lll}\text { A1 } & \text { B } & \text { A2 }\end{array}$

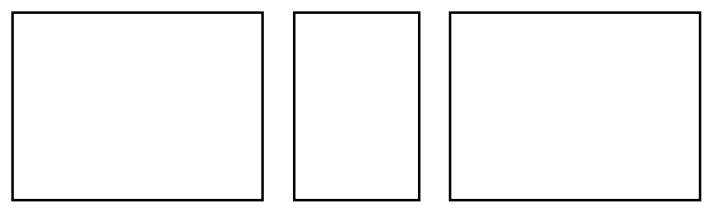

mm. 1-39 $\left[\begin{array}{l}\text { mm. 40-48 } \\ \text { "beklemmt" }\end{array}\right] \mathrm{mm} .49-66$

Figure 1 Beethoven, String Quartet in B-flat Major, Op. 130, Cavatina, the ABA structure

constricted center should not be there. If, as Lévinas suggests, the human being is not Dasein ("being there") but Utopia (literally, "being nowhere"), ${ }^{192}$ then the beklemmt section is human by virtue of having no formal position. Structurally, it should serve as a transition, a temporal function normally subsumed by the formal economy as a link between the A sections. But this link is "a transition to nowhere" since the outer segments are tonally and thematically self-contained, requiring no harmonic connection. The transition cannot be grasped because it is superfluous. Its movement from C-flat major to A-flat minor was originally a transition to "somewhere" in the Opus 110 Sonata from which it derives (see Ex. 6), but in the Cavatina it merely disconnects the form as a redundant function. Thus the center finds itself dis-placed as a stranger and sojourner, surfacing like some repressed memory in the "wrong" piece and the "wrong" key.

With the untimely and unseemly arrival of the "nowhere" (the human) from "elsewhere," the position of the form is put into question. Its conceptual

opposition to the "synchrony of representation" in which the ego synthesizes what it sees in the present; "diachrony" is the harmonization of different temporalities without reduction.

192. Johan F. Goud, "Wat men van zichzelf eist, eist men van een heilige: Een gesprek met Emmanuel Lévinas," Ter herkenning 11 (1983): 85-86, cited in Hent de Vries, Minimal Theologies: Critiques of Secular Reason in Adorno and Lévinas, trans. Geoffrey Hale (Baltimore: Johns Hopkins University Press, 2005), 371. 
present (its main-tenance) is disturbed by an ungraspable past. Instead of placing the "no place" within its symmetrical structure, the form of the Cavatina re-conceives its center as an opening in which the asthmatic material is given space to breathe. Sensing the trace of another work, the outer sections simply draw back without impinging on the material. There is no motivic, thematic, or harmonic attempt at integration at the points of contact. They give way to create a clearing in which an Other can give itself. The paradox of "giving way" - the donation of distance-is the reception of the Other. Adorno calls this "distanced nearness." 193 It is a "relation without relation" in which time is given (distance) in order to host (nearness) the delayed presence of alterity. ${ }^{194}$ Structurally, this (non)-relation is reflected in the harmonic homonyms between the outer and inner sections of the Cavatina, where the same sounds bearing different meanings simultaneously close and open the gaps that partition the centre of the form. The $\mathrm{E} b$ tonic that concludes the $\mathrm{A}^{1}$ section lingers into the "constricted" center as a pulsation of triplets that pave the way for the emergence of the beklemmt melody; but with the latter's appearance, the $\mathrm{Eb}$ suddenly finds itself disjointed as the mediant of C-flat major (Ex. 5, mm. 39 and 42 , violin 2). Similarly, the $\mathrm{F} b-\mathrm{E} b$ sigh that closes the beklemmt section is estranged in the very next measure with its repetition at the beginning of the $\mathrm{A}^{2}$ section; what was a motion toward the dominant of A-flat minor (m. 47: cello) is suddenly transformed into a Neapolitan cadence in E-flat major (m. 48). In both cases, the harmonic syntax is short-circuited, as if to preserve the strangeness of the Other, and yet this sense of juxtaposition is mediated by identical sounds. Thus the violence of the formal disruption is structurally noncoercive, for the sense of estrangement is one of reception just as its distance is one of nearness. "Only by the recognition of distance in our neighbour" writes Adorno, "is strangeness alleviated: accepted into consciousness. The presumption of undiminished nearness present from the first, however, the flat denial of strangeness, does the other supreme wrong, virtually negates him as a particular human being and therefore the humanity in him, "counts him in,' incorporates him in the inventory of property." 195

To state that the Cavatina is in some kind of ternary or Da Capo form so typical of this operatic genre would be correct, but only inasmuch as its structure is mistaken as a monad. The movement, after all, is not some totality that conceptualizes the nonidentical as the same, for the beklemmt section is an unnecessary structural gesture that suspends the form at its center. If a form has to be designated, then the Cavatina demonstrates a form of hospitality, which

193. Adorno, Minima Moralia, 90. This phrase sums up a passage on the gaze of human relationships: "But in the long, contemplative look that fully discloses people and things, the urge towards the object is always deflected, reflected. Contemplation without violence, the source of all the joy of truth, presupposes that he who contemplates does not absorb the object into himself: a distanced nearness" (89-90).

194. Lévinas, Totality and Infinity, 80.

195. Adorno, Minima Moralia, 182. 
is a non-form in so far as it fails to absorb the "transition-to-nowhere" somewhere within its ranks. As Lévinas writes: "the welcoming of the other by the same" disturbs the totality of the Same with the infinity of an Other. ${ }^{196}$ The beklemmt section leaves its trace in a form where the absolute character of alterity - its infinite irreducibility - finds a temporary place to be.

A shelter for alterity is contrary to Adornian thought: it denies critical theory of the alienation it champions. So for Adorno, the Cavatina does not host the stranger but is itself estranged, forcing the hand of the composer to release its conceptual grasp of the material; all that is retained of the form is the outline of what is no longer there. "Nowhere" is not the human, for Adorno, it is merely a place-holder to be left vacant for the future. "The dying hand" writes Adorno concerning the Cavatina, "... releases what it has previously clutched fast, shaped, controlled, so that what is released becomes its higher truth."197 There is no hospitality here: Beethoven's fist opens to receive nothing; it yields to distance without nearness; the "dying hand" surrenders its possession as a final act, a farewell to form. Form in late Beethoven is therefore a trace of the concept for Adorno, an apparition whose absent presence is figured as a convex hole punctured by escaping subjectivity. What Adorno calls "hollowness turned outwards" are the vanishing outlines of this convex shape that formal types tend to delineate in their grasp of the material. ${ }^{198}$ In this sense, the beklemmt section could be perceived as the after-image of these forms- the curve of an arch-form, the apex of a ternary structure, the bend of a transitory "bridge" passage, or even a Schenkerian Urlinie as it turns back from an upper neighbor-note motion. ${ }^{199}$ But the form of the Cavatina is, in fact, the inverse of Adorno's convex holes. Indeed, its shape returns to the etymological origin of the word "concept," not as the German "Begriff," but as the Latin "conceptus": an entity that is concave. Form is a basin, a shape that receives, evoking "the gesture of 'welcoming' rather than that of 'grasping.' "200 The outer sections of the Cavatina therefore delineate the rim of a hollow, not in the way that Adorno might construe it-as a hole pushed out by the escape of the subject-but in the way Merleau-Ponty perceives it-as the very shape of the subject itself (Fig. 2). The hollow ( $\operatorname{creux}$ ) for Merleau-Ponty "expresses the encounter of subjectivity with the world," 201 an encounter in which the

196. Lévinas, Totality and Infinity, 43.

197. Adorno, Beethoven, 193. To illustrate this idea Adorno cites the Cavatina, but not the last measure or the beklemmt section; he refers to measures $23-30$ where a cadential cliché is repeated.

198. Ibid., 126.

199. The Schenkerian Urlinie evolved from a symmetrical convex structure, evident in earlier graphs, with an initial ascent mirroring the final descent. In the case of the Cavatina, a convex Schenkerian shape is outlined by a large neighbor-note motion from G, prolonged in the initial section, rising to $\mathrm{Ab}$ in the middle section before returning to $\mathrm{G}$ in the final section.

200. Carbone, Thinking of the Sensible, 47.

201. See ibid., xvi. 
convex presence

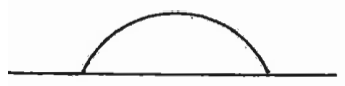

Tradition form:

"grasping" the material within its convex outline convex absence

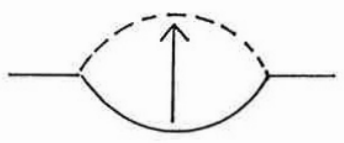

Adorno's negative image:

"Hollowness turned outward" as subject escapes, releasing the materials concave

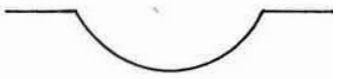

Conceptus:

a formal welcome

Figure 2 Three formal shapes

subject is simultaneously active and passive, no longer the author of its thoughts but a chamber in which the Other resonates, like a "melody [that] sings itself within us much more than we sing it"; "the body," he writes, "is suspended in what it sings" in the same way that the resonance of the beklemmt melody suspends the formal symmetry of the movement. ${ }^{202}$ The Cavatina registers the metaphysics of the particular as a form of reciprocation that gives (way) by receiving what is given. This gift is Beethoven's "gift of sight." The eyes that pierce through the formal fractures speak of the reception of the Other and not its alienation. In the concave structure of the Cavatina, what is rendered invisible by the instrumentality of modern vision is made visible by a receptive distance that draws back for the infinity of the Other to "show itself . . . [by] giving itself." The hollow, in the words of JeanLuc Marion, allows for the "individuation of the Other"; it reaches the Other "in his unsubstitutable particularity, where he shows himself like no other Other can. This individuation," states Marion, "has a name: love."203

If, in the hollow of the Cavatina, the form hosts an encounter with estrangement, then its expression of love is primarily "structural" and not emotional, despite the excess of Empfindung. So what is the structure of love-its "formal law," as it were? Love, writes Judith Butler, is "our willingness to become undone in relation to others"; it "constitutes our chance of becoming human."204 The decision to "give way" in the Cavatina is structural only as an

202. Maurice Merleau-Ponty, Nature: Course Notes from the Collège de France, ed. Dominique Séglard, trans. Robert Vallier (Evanston, IL: Northwestern University Press, 2003), 174; quoted in Carbone, Thinking of the Sensible, xv; translation modified by Carbone. The inspiration behind Merleau-Ponty's ideas here is Proust.

203. Marion, Being Given, 323-24.

204. Butler, Giving an Account of Oneself, 136. Although love is not specifically mentioned in the closing paragraph of the book from which the quote is taken, it is implied in the context of the overall argument; in particular, it summarizes the discussion on love and fallibility in Adorno's thought (101-11). 
undoing of structure, an injury that indents a space for the transient particular to resonate within a permanent relationship. Its fleeting appearance, no more than 10 measures in a 66-measure movement, is preserved with all its sensory immediacy precisely because it is hosted and not subsumed. A concave form, then, is always in some sense wronged by the Other and, counter to theories of musical form, it does not exercise the right to correct itself. ${ }^{205}$ Hence the failure to integrate the constricted center of the Cavatina results in a lopsided rendering of its projected symmetry: the final A section is severely telescoped on account of the brevity of the beklemmt section in order not to overwhelm the delicate aura of difference. ${ }^{206}$ The formal disunity at the center of the form is not merely the crucible for critique that Adorno advocates in late Beethoven; it is the structure of love. To reconceive the structure in this wayfrom the convex to the concave- is to convert form as an exclusionary practice that expels foreign bodies in order to maintain its internal integrity, to one where form loses its grip on the purity of its content, preserving a differencein-relation. Miroslav Volf, employing another concave metaphor, calls this kind of gesture "the will to embrace"; it describes a process of self-donation "prior to any judgement about others, except that of identifying them in their humanity." 207 This embrace, for Volf, does not simply welcome the other, but always ends with a release that is the beginning of another embrace in an unending process of recognition and differentiation. ${ }^{208}$ Volf's open gesture of

205. In a recent article, "Normalizing the Abnormal: Disability in Music and Music Theory," this Journal 59 (2006): 113-84, Joseph N. Straus offers a music-theoretical ethics of the dysfunctional body. Straus argues for the embodiment of disability within music from the turn of the nineteenth century in which abnormal or deformed elements are normalized through processes of tonal resolution; this strategy is reflected in the music analytical discourses of form theorists such as A. B. Marx, and the organic of theories of Schoenberg and Schenker. Straus understands the process of normalization as one of healing and overcoming, although there is a tension between the ethics of his own analyses and the ideas of the theorists he cites for whom the abnormal is stigmatized as paralyzing or deformed. From the latter perspective, normalizing the normal could be construed as less humane; indeed, one could take a more Foucauldian position on nineteenthcentury medical practice and see the normal as a way of disciplining and defining the abnormal. After all, the musical process defined by the theorists is akin to a judgment in which the disabled are reformulated under a concept (the normal). In Lévinasian terms, the Other is subsumed under the Same; or in Adorno's terms, the nonidentical is suppressed by the identical. The issue boils down to whether the musical anomaly is seen medically or humanly: is it an illness (a bad thing) to be healed or a person (not a thing) whose infinite value remains the same whatever her condition? The beklemmt section is obviously an expression of vocal disability. However, this voice represents a person; it is therefore not an illness to be overcome but is someone to be received; it is not healed, but loved. Music's normalizing process (judgment) is suspended in order to allow the "who" and not the "what" to be seen.

206. The first A section is 39 measures long, whereas the final A section, filling only 18 measures, is roughly half the original length.

207. Miroslav Volf, Exclusion and Embrace: A Theological Exploration of Identity, Otherness, and Reconciliation (Nashville: Abingdon Press, 1996), 29.

208. Ibid., 145 . 
deferred closure provides an analogy for the formal processes at work in the Cavatina. Not only is the form "concave" with the A sections delineating a space in which the beklemmt melody resonates; the form also ends with a release. Having embraced the stranger, the final A section gives way again, relinquishing the formal need to recapitulate its secondary material. As the movement draws to a close, the "constricted" material quietly resurfaces (mm. 5766); it illuminates the thematic contours until it indwells the last chord by recalling the asthmatic center in its final breath with its articulated tied notes. But this breath is not a generalized reference; it is an exact reenactment of the breath that concludes the beklemmt passage (mm. 46-47). ${ }^{209}$ The only difference is notational; with the final chord, Beethoven has replaced the "hairpins" with words (crescendo, piano, diminuendo), but the dynamic shape remains the same (Fig. 3). The glance at the center seems to be reflected toward us from the inside out, as if the closing gesture demands of us a response- "a call" from the unknown to return the gaze and embrace the Other.

\section{Incognito}

The Other's relation to the Self, then, is akin to "a call." But as the outer sections of the Cavatina give way to embrace an Other, it is unclear who is calling. To whom does the Self return the gaze? Since an aural optics sees nothing, merely conceding a space for "nowhere" to be, whoever is revealed as Other always remains in some sense "empty." Indeed, the emotive lure of the beklemmt section is predicated on emptiness itself, not only by assuming the form of a song bereft of words, but by imitating speech in the act of speechlessness. Its failure to speak invokes an Other who cannot be re-presented because it cannot re-present itself and so remains opaque to the subject's grasp. According to Marion, the call of the Other must stay anonymous if its summons is not to be appropriated as an object of knowledge. Anonymity is the prerequisite for the nonidentical to survive: "In conformity with the principle of insufficient reason," writes Marion, "the claim [of the Other] does not have to become cognized in order to become recognized, nor does it have to be identified in order to be exerted. Only this poverty is sufficient to wound subjecti(vi)ty and exile it outside of any authenticity." 210

In this light, the poverty of the musical sign acts as the wound that exiles the subject; its blankness articulates the sonority of a face that surprises the subject with the shock of the unknown. Marion regards this as a temporal condition, a delay in knowledge between the surprise and the claim. "The call

209. On the thematic transformation at the close by the beklemmt material see Chua, "Galitzin" Quartets of Beethoven, 198.

210. Jean-Luc Marion, "The Final Appeal of the Subject," in The Religious, ed. John D. Caputo (Oxford: Blackwell, 2002), 142. 


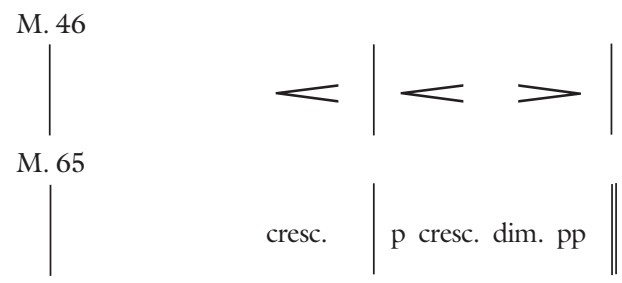

Figure 3 Beethoven, String Quartet in B-flat Major, Op. 130, Cavatina, dynamic similarity between $\mathrm{mm} .46-47$ and $\mathrm{mm}$. 65-66

[of the Other]," he states, "comes to an understanding only belatedly awoken, after having already begun to finish, already in the twilight of its dawn." 211 The other is always future, as Lévinas would insist, always yetto-come. Or in ethical terms, when Volf defines the "will to embrace" as an operation "prior to any judgement about others," the suspension of judgment is designed to delay the identity of the Other. The only presupposition for Volf is that the anonymous are received "in their humanity" as if this constituted the bare facts of alterity. ${ }^{212}$ The human, it seems, can only be seen without seeing because there is nothing to see, but only the time of seeing that demands an infinite patience. It is for this reason that love is blind. And if the anonymous are to be received only "in their humanity," whatever is disclosed after the temporal delay cannot alter that humanity; the delay merely figures a permanent "blank," a nothingness that remains within the Other. The Other is, therefore, an empty sign: "nothing" is the minimal condition of humanity. Of course, this "nothing" is a far cry from the void that forms the delusion of the subject's auto-genesis. It is not that "nothing" constitutes the human, or that "nothing" articulates its founding gesture; rather it affirms that even if there is no-thing to this person-no redeemable quality, no "what" that can be assigned to the "who"- the one before me in her privation and poverty is still fully and uniquely human. The Cavatina's empty sign gestures to the plenitude of the Other in an act of kenosis.

At first, it may appear ironic that the Cavatina should inscribe the face of the Other as a kenotic act; alterity is not the native tongue of a genre so closely aligned with opera. ${ }^{213}$ From its inception in the humanism of the late sixteenth century, opera has staged the sonorous spectacle of the modern ego. Sovereignty, not anonymity, is its theme. In operatic theory, sung speech is

211. Ibid., 143.

212. Volf, Exclusion and Embrace, 29.

213. Joseph Kerman in The Beethoven Quartets (Oxford: Oxford University Press, 1967), 196, states: "The Cavatina assumes a thoroughly operatic stance. Vocality is more than evoked. It is practically transcribed." 
the instrument by which the subject manipulates the signs of language to represent what its surveys as an immediate affect on its audience. The stile rappresentativo, as it was called, pictures the world as a synchronic moment in order to control the emotive state of another's soul. ${ }^{214}$ And Beethoven's Cavatina bears traces of this ancestry: the sighing semitones, the stuttering syllables, the breathless syncopations, lifted from the Baroque taxonomy of emotive figures, are deployed to wring from our eyes the tears that Beethoven supposedly shed every time he thought of the work. ${ }^{215}$ But the Cavatina's emotional ploy goes beyond the manipulation of operatic formulas. By removing language from the very style designed to represent it, Beethoven heightens the force of the emotive will, endowing its operatic gestures with an ineffability that overwhelms the taxonomic representation of the signs. To borrow Kerman's phrase, the Cavatina seems to be "battering at the communications barrier," straining for a language beyond language. ${ }^{216}$ In effect, the transformation of the Baroque figures into speechless rhetoric endows the operatic subject with the infinite yearnings of the romantic ego, bending the outward gestures of Baroque spectatorship toward an inner audition that sounds out the pre-linguistic source of the self. ${ }^{217}$ The Cavatina is therefore the fusion of operatic affect and romantic song, of an outward spectacle and an inward gaze.

But as such, it is also a contradiction, for the outward staging of the subject's inward voice undermines the music's authenticity. It is as if the more the subject tries to recover its originary presence, the more it discovers the operatic artifice of its song, turning the moment of unmediated emergence into a stage-managed event. Bourgeois inwardness, as Adorno points out in his critique of Kierkegaard, resembles the interior decoration of nineteenth-century homes in which the subject's identity is emptied out as standardized objects in a living room. ${ }^{218}$ Perhaps it is for similar reasons that some of the most perceptive commentators on the Cavatina cast doubt on its sincerity; its emotive force merely manipulates the listener with a display of inwardness that is nothing more than theatrical sophistry. To guard their critical faculties, these commentators feel compelled to defend themselves from the affect these gestures are supposed to elicit, either by detecting something "crass" about the

214. See Chua, Absolute Music, 29-60; and idem, "Untimely Reflections on Operatic Echoes," 573-79.

215. See Lenz, Beethoven: Eine Kunststudie, vol. 5, pt. 4, p. 217; and Thayer, Thayer's Life of Beethoven, 975.

216. Kerman, Beethoven Quartets, 194.

217. See Wellbery, Specular Moment, 22. The originary song is not simply a romantic notion, but takes its cue from the operatic theory of the seventeenth century. See Chua, Absolute Music, $29-40$ and $98-113$.

218. See Theodor W. Adorno, Kierkegaard: Construction of the Aesthetic, ed. and trans. Robert Hullot-Kentor (Minneapolis: University of Minnesota Press, 1989), 43-44. 
music, ${ }^{219}$ or by declaring the movement a "mock cavatina" whose tears require ironic distance rather than empathy. Hence the Cavatina, as Richard Kramer puts it, needs to be treated as a "fiction." 220

But the beklemmt section, as a moment of kenosis, already certifies itself as a fake. The "fiction" is acknowledged in the performative collapse that allows the rhetorical husk of language to surface as feigned expression. This may appear, at first, to be a rehearsal of Adorno's aesthetics, in which conventions are released as a memorial of the subject's departure. However, in the beklemmt section, the operatic clichés are not surrendered as untouched debris; rather the subject seems to seize them, indeed, to strangle them, producing the expressive "constriction" of the music. But in seizing the object, the subject itself seizes up, or more aptly, collapses into seizures. It is as if the subject, in reaching the liminal point of self-expression, passes over into the object and petrifies into convention. These formulaic figures, although saturated with subjective intention, are devoid of subjective control, becoming the involuntary twitches of some prefabricated speech; the linguistic breakdown exposes the data of emotion as a "discourse" prior to the subject. What undergoes kenosis, then, is not so much the subject as its performance, unmasking the theatricality of self-presence. ${ }^{221}$ Indeed, the Cavatina traces the history of this interior fabrication. First, by alluding to Empfindsamkeit, it recalls the sentimental aesthetic of the mid-eighteenth century in which private life-in the form of intimate letters and diaries - was staged as a spectacle of public virtue; the formation of the "public sphere," as Jürgen Habermas describes it, bears a sense of bourgeois inwardness projected outwards.222 Secondly, as romantic song, the Cavatina updates this dichotomy, becoming the very vehicle through which the subject displayed its inner being in the early nineteenth century. So in revealing the operatic mechanism behind the subject's production of meaning, the Cavatina points to the anxiety of performance in being human. The ego's authenticity is an act produced with social props, fraught with stage fright, burdened with the compulsion to repeat, to rehearse, to perfect, to perform. Music's increasing interiority does not provide a refuge from social pressures,

219. Kerman, Beethoven Quartets, 198. While acknowledging the emotive effect the Cavatina has had on numerous commentators, Kerman points out the "crass melodic and harmonic construction," perhaps to distance himself from the tear-jerking strategy of the music or maybe to suggest that that the crassness is the source of the effect itself.

220. See Richard Kramer, "Between Cavatina and Overture: Opus 130 and the Voices of Narrative," Beethoven Forum 1 (1992): 181. Kramer hears the theatrical fiction of the Cavatina only in relation to the Grosse Fuge; in itself, the Cavatina is real enough; indeed he refers to it as "the direct, pure language of the lover's soliloquy, altogether without artifice" (187) and yet, its repudiation by the narrative voice of the fugal finale renders its pain the expression of a "fictional character" acting a part (184); its ultimate reality is staged.

221. See note 133 .

222. See Jürgen Habermas, The Structural Transformation of the Public Sphere: An Inquiry into a Category of Bourgeois Society, trans. Thomas Burger (Cambridge, MA: MIT Press, 1991), $43-51$. 
but bears witness to a society of surveillance, in which the inner self is judged by the public account it gives of its integrity: I am because I perform. The Kantian "I think," despite (or even because of) its noumenal inaccessibility, is a display that presents the subject as present; it is a being "having to speak, having to say $I$. . having to answer for one's right to be," writes Lévinas. ${ }^{223}$ The very failure to perfect that performance warrants an eviction from the reality show that is human society. The subject's appearance is therefore an internal process of self-performance that excludes itself as "Other" the moment it fails to re-present the truth of its inner being.

And it is precisely this moment that the beklemmt section captures. It stages the no-thing that remains after the inner display has collapsed, revealing the nakedness beneath. Shame - the emotion of exposure-is the content of the music's inarticulate eloquence. In fact, it enacts the very blush that the critics feel compelled to distance themselves from in their exposure to exposure, for this is an "anti-performance," a moment of public humiliation. The face of the Other is seen in the loss of face. So the point of all the operatic trappings, with its "crass" effects and "mock" gestures, is to designate a site of performance where one can be utterly exposed. As Lévinas writes, the face of the Other is "extreme exposure, no defence, vulnerability itself." 224 Opera turns out to be the perfect platform for kenosis.

But this kenosis is not merely the result of its staging; it is literally inscribed in the score. The Cavatina's expression of vulnerability is one of melodic exposure: Beethoven desynchronizes the "vocal" line, leaving its notes naked in the gaps between the underlying pulsations, as if it were unable to cover the barrenness of its existence. In particular, he isolates the beginning or end of each phrase as a separate note. Although part of a sentence, the isolation turns the anacrusis or cadence into some kind of speech impediment in the phrasea moment of hesitation or the superfluous syllable of a stutter. These naked notes are an articulation of inadequacy because they are the waste products of meaning; they strip the ego of its performance, exposing its failure to account properly for itself. So what is left after this failure? By preventing its voice from presenting song as its mode of being and in articulating the physical impediments of speech, the Cavatina gestures to the malfunction of the body as the only condition of narration that one could provide when the very definition of man as "one endowed with language" is no longer adequate to the particular. 225 "There is a bodily referent here," writes Butler in reference to the human, "a condition of me that I can point to, but that I cannot narrate precisely." This "non-narrativizable exposure," she continues, "establishes my

223. Lévinas, "Nonintentional Consciousness," 130; reiterated in "From the One to the Other," 144.

224. Lévinas, Alterity and Transcendence, 24.

225. This refers to Aristotle's definition of man as logos, whose primary meaning is "language"; see, for example, Hans-Georg Gadamer, "Man and Language," in Philosophical Hermeneutics, ed. and trans. David E. Linge (Berkeley: University of California Press, 1976), 59. 
singularity" but it also indicates a "partial opacity to myself" which can never be accounted for let alone narrated by the norms of address "that I do not author and that render me substitutable at the very moment that I seek to establish the history of my singularity." 226 The Cavatina, in its inarticulate eloquence, testifies to the opaque singularity of a body unable to account for itself and, which renders its identity unknowable - even to itself. Beethoven has transformed the sentimental display of auto-affection in Empfindsamkeit into an expression of deprivation. In this minimal condition, the human is simply that which is forsaken, a refugee abandoned with neither possession nor self-possession. In the semblance of the denuded and through the gaps of the suffocating silences, there is a "nakedness [in the Cavatina] that cries out its strangeness to the world." 227

Lévinas would found an ethics on such an exposure: "The suffering and vulnerability of the sensible," he writes, is "the other in me." 228 Unlike the recapitulation in the first movement of the Ninth Symphony, the defenseless face stands for an ethics that does not "stand firm": it "resists without resisting"; there is no "self-crafting" against the imposition of social norms, no mimesis of fear, no invention of freedom that stares fate in the face. Rather, in contrast to the sublime monad, the face of the Other, in its physical vulnerability, commands without force. ${ }^{229}$ It is "all weakness and all authority" claims Lévinas;230 "Those eyes," he writes, "which are absolutely without protection, the most naked part of the human body, nonetheless offer an absolute resistance to possession." ${ }^{231}$ Hence, for Lévinas, the vulnerability of the face "tempts ... the first crime" - to kill. And yet this very alterity interrupts the sovereignty of the self with a "glory" that Lévinas assigns to "the word of

226. Butler, Giving an Account of Oneself, 38-39.

227. Lévinas, "Totality and Infinity: Preface to the German Edition," in Entre nous, 198.

228. Emmanuel Lévinas, Otherwise than Being, or, Beyond Essence, trans. Alphonso Lingis (Pittsburgh: Duquesne University Press, 1998), 124-25.

229. See Lévinas, "Diachrony and Representation," 172. Unlike Adorno, Lévinas, with his adherence to the biblical prohibition against graven images, prevents the possibility of actually seeing the face in art-such an image would be idolatrous, if not blasphemous; see Emmanuel Lévinas, "Reality and Its Shadow," trans. Alphonso Lingis, in The Lévinas Reader, ed. Seán Hand (Oxford: Blackwell, 1989), 131-32; the essay is also in Lévinas, Collected Philosophical Papers. To see the face in the Cavatina, then, would de facto reduce the human to an idol. It is not that Lévinas's position is untenable, but that it is too general. There are alternative views; in particular, I have alluded to the work of Jean-Luc Marion, who argues that the image should not always be held captive by the biblical ban, but that a distinction needs to be made between idol and icon (what is made and what is given, seeing and being seen). And, of course, there is Adorno himself, whose commitment to the Bilderverbot does not prevent him from seeking the truth of the "imageless images" of art (Aesthetic Theory, 283 and 287). On Lévinas and the Jewish prohibition of image, see Jay, Downcast Eyes, 546-60. On Lévinas and art, see de Vries, Minimal Theologies, 409-42; and Lévinas, "Philosophical Determination of the Idea of Culture," 182-84.

230. Lévinas, Alterity and Transcendence, 105.

231. Emmanuel Lévinas, Difficult Freedom: Essays on Judaism, trans. Seán Hand (Baltimore: Johns Hopkins University Press, 1990), 8. 
God."232 What illumines the face is the divine command: "Thou shalt not kill." 233 Adorno's "imponderably delicate aura of the other" turns out to be the indelible law of the transient particular; the "formal law of freedom" is undone by the absolute command of an ephemeral glance.

If the written law_- "Thou shalt not kill"—-speaks through the singularity of a face, then Lévinas's ethics is, in a sense, incarnational: the face is the Word made flesh. ${ }^{234}$ The law has been particularized in a body, in a person, in a gaze. Could this gaze, then, be the face of God in Christ, reflected in the countenance of the Other? ${ }^{235}$ Are these the "sad eyes" in Beethoven's music that "speak to us and wait . . . for us to answer"? ${ }^{236}$ After all, the face of Christ is similarly defenseless and exposed, a face subject to public humiliation and condemned because it failed to account for itself; in its human vulnerability, his face tempts us to murder and yet, in the penetration of its gaze, dis-places our "Da-sein."237 If the Other who calls us to be is Christ rather than some Platonic or Aristotelian universal, then "the particular is . . raised to ontological primacy," states Zizioulas, affirming the inviolability of the unique "I am" of each person. ${ }^{238}$

This is not to claim that the suffering that contorts the face of the Cavatina is a direct vision of Christ incarnate. Such a claim would nullify the very possibility of the vision, for Christ is the unseen face of the Other, an image that so identifies with the destitute that even his followers cannot recognize him in the face of poverty: "Lord, when did we see you hungry and feed you, or thirsty and give you something to drink?"239 His call, to echo Marion, is anonymous. He is "no one." The God-man, as Søren Kierkegaard insists, comes "incognito";240 his absolute anonymity constitutes his true humanity.

232. Lévinas, Alterity and Transcendence, 24, 28, and 27. The "first crime," of course, pertains to Cain's murder of Abel in Genesis 4.

233. Lévinas often quotes this idea: see, for example, ibid., 24, and idem, "Diachrony and Representation," 168.

234. Lévinas wants to avoid the idea of the face as an image, especially in relation to art, for that would already constitute some kind of mask or caricature of the face: hence his alignment of face with word. The theological idea of being "made in the image of God," that is, made in his "likeness," implied in the following discussion is therefore not a literal image that functions as a substitute for truth, as if image were separate from being; rather the image is constitutive of being human. In Adorno's terms, it is the elusive "aura" that radiates from within (and is) our material being, and yet cannot be reduced to plastic or physical features.

235. Lévinas himself gestures toward the Christological resonances of his thought in "A Man-God?" in Entre nous, 53-60.

236. Adorno, Beethoven, xi.

237. See Luke 22:61-62 (NIV).

238. Zizioulas, "On Being a Person," 43. Thus, for Zizioulas, the answer to the question "Who am I?" no longer reduces the "I" to a mere derivative of nature, but affirms the uniqueness of its being as ontologically caused by a particular person.

239. Matthew 26:37 (NIV).

240. Søren Kierkegaard, Practice in Christianity, trans. Howard V. Hong and Edna H. Hong (Princeton, NJ: Princeton University Press, 1991), 127-33. 
The incarnation, then, is paradoxically an invisible materialization that requires an alterior optics to render present what is absent to the modern eye. It is without image. Thus Beethoven's "gift of sight" in the Cavatina cannot be the direct gaze of Christ. But inasmuch as Christ in becoming man, "became nothing," embodying the vulnerability of humanity in the act of kenosis, ${ }^{241}$ any music that partakes of this suffering bears the "nothingness" of his Imago Dei. In fact, Beethoven suggests such an affinity, for the breathing apparatus at the center of the Cavatina bears a close resemblance to the "Crucifixus" at the center of the Missa solemnis. Marked "Adagio espressivo," the "Crucifixus" transforms the somatic gestures of Empfindsamkeit into the suffocating body of Christ; the wounds are marked in the score by the same respiratory symptoms encountered in the Cavatina - the fragmentation of the violin line as it gasps for air, the syncopated "Bebung" accompaniment that can barely lift the ribcage of the crucified body (Ex. 7). ${ }^{242}$

Significantly, Adorno detects a "humanistic aspect" here disturbing the coldness of the Missa; starting with the "et homo factus est," "the music," he writes, "is warmed as if by a breath." 243 This breath begins with another one of those isolated stutters, a superfluous repetition of the least significant word of the text, "et" [and]: "et et homo factus est" (mm. 143-144). But the redundant "et," which is something of a recurring tic throughout the Credo, 244 takes on its human poignancy only in the expiration of the very breath that Adorno hears. The first "et" of this section is a rhetorical accentuation, un-

241. See Phillipians 2:6-8 (NIV).

242. Beethoven's religious outlook is often classified as Deistic, with Masonic undertones (and sometimes Buddhist or Hindu overtones), although it is difficult to pinpoint his beliefs from the available documents; see, for example, Maynard Solomon, Late Beethoven: Music, Thought, Imagination (Berkeley: University of California Press, 2003), 135-212. However, these exotic religious variations, although useful in propping up his Promethean image, should not exclude Beethoven's Christian heritage as a source of influence, nor eclipse the obvious fact that his religious music is overtly Christian. Indeed, Cooper, in Beethoven, 272-73, points out that in the last decade of Beethoven's life, his religions inclinations became more and not less Christian. His faith focused particularly on the suffering of Christ. In 1820 Beethoven stated that Jesus (along with Socrates) was a model of endurance for him; see Ludwig van Beethovens Konversationshefte, ed. Karl-Heinz Köhler et al., 11 vols. (Leipzig: VEB Deutscher Verlag für Musik, 1968-), 1:211. He contemplated composing an oratorio on the crucifixion itself, and among the sketches for material used in Opus 130/133 are ideas for a Dona nobis pacem (Autograph 11/2, Staatsbibliothek zu Berlin). Although this work did not materialize, the idea surreptitiously resurfaces in a number of compositions. David B. Levy in " 'Ma però beschleunigend" " relates certain figures in the Cavatina, the Credo of the Missa solemnis, and the Grosse Fuge to the Crucifixus of Bach's BMinor Mass. But even without such connections, the sense that this music portrays the death of Christ is often intuitively felt: Alfred Brendel and Wilfrid Mellers, for example, regard the arioso of Opus 110 quoted in the Cavatina, as "Passion music"; see Brendel, Alfred Brendel on Music (Chicago: A Cappella Books, 2001), 87; and Mellers, Beethoven and the Voice of God (London: Faber, 1983), 287.

243. Adorno, Beethoven, 149.

244. See mm. 179-80, 188, 212, and 235 . 
Example 7 Beethoven, Missa solemnis, Credo, mm. 173-176 (string section)
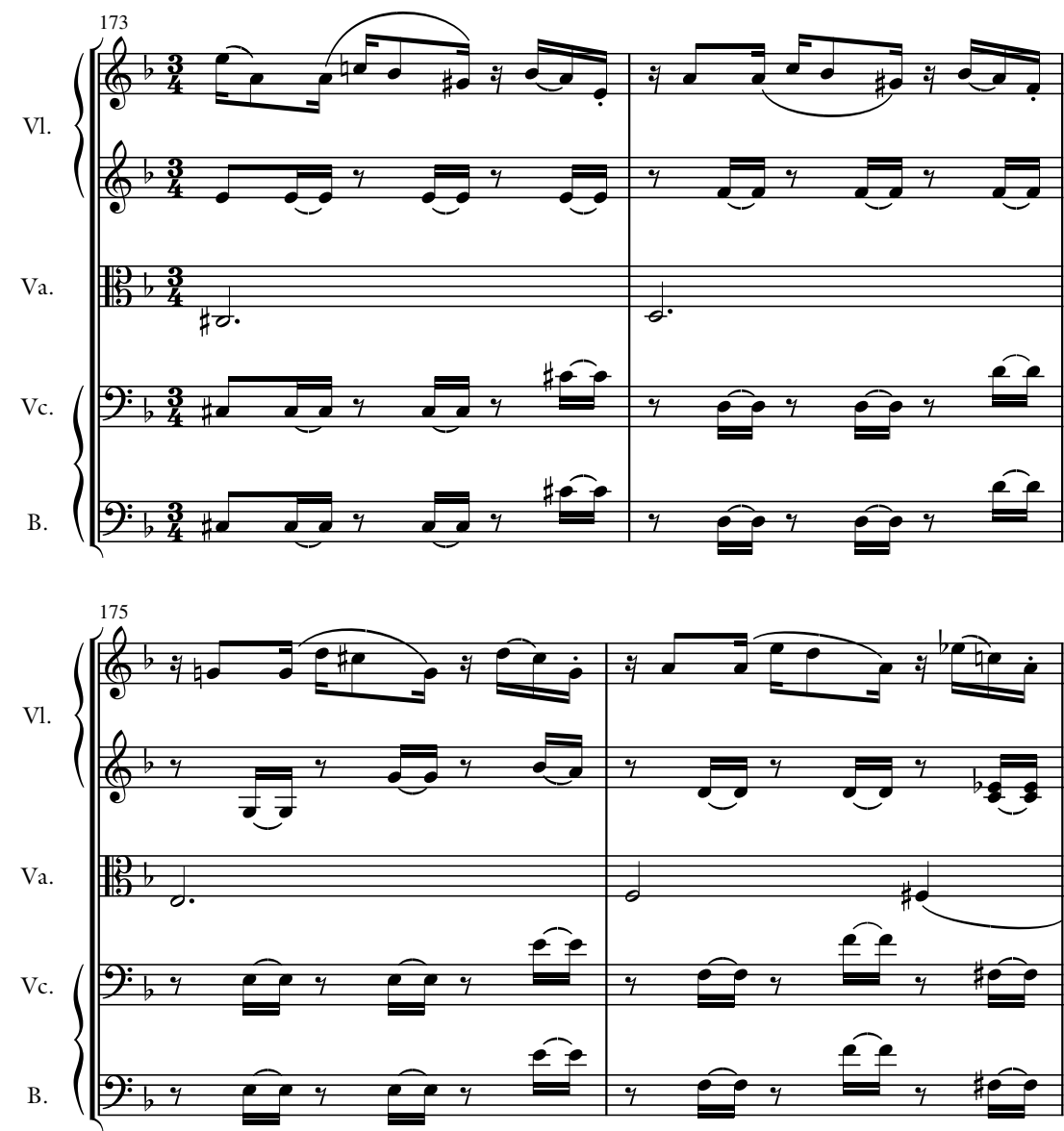

furled with the full force of the orchestra behind it as if to endow the incarnation with a sense of nobility ("and ...AND was made man"); by the end, however, it becomes the dying stammer of a suffering body- "passus . . et ... et . . . sepultus" ("suffered and . . . and . . . was buried"). It is here, "at the end of the Passion itself," writes Adorno, that "an expressive emphasis is reached, as if the thought of the frailty of human beings had brought attention back to the Passion of Christ." 245 This disjunct articulation of a grammatical 
conjunction suddenly finds its meaningless utterance meaningful in the voice of one cut off from life in the final twitches of suffering (Ex. 8). ${ }^{246}$

Adorno may contend that the sovereignty of the Missa is founded on a law of exception in which Beethoven himself is excluded from his work, but the passages that portray Christ as excluded are precisely the "exceptional" moments in the Mass for Adorno; 247 they form, as it were, the exception against the law of exception and so point to the possibility of another order that might be truly human. In Christ, Beethoven has somehow been included again in his work, but now as the Other; indeed, for Adorno he literally leaves his face on the Missa's edifice, like "the custom attributed to late medieval artists, who included their own image somewhere on the tabernacle." 248 Through this fellowship of suffering in which the excluded are redeemed, Beethoven's countenance is transfigured by the alterity of Christ-in-the-Other. It is at such points - at the minimal moments of human life - that the Missa identifies with the no-thing of the Cavatina, breathing in solidarity with the anguished and constricted. Or to put it the other way round, in its mimesis of suffering, the Cavatina assumes the nature of humanity inasmuch as the crucified Christ, to borrow the words of the Nicene Creed, "became truly human"_- "et homo factus est." 249

Who, then, is the Other in the Cavatina? The human is both some-body and no-thing: a disclosure and erasure; Christ incognito. On the one hand, as David B. Levy suggests, the Cavatina, in its allusion to the Missa solemnis, evokes "the weeping and agony of the Garden of Gethsemane";250 the passion of Christ is inscribed in its gaze. Yet it is only the speculative ear that can "see" the gaze, for the Cavatina neither makes the face explicit nor offers some Christological code to be deciphered. ${ }^{251}$ There is nothing to appropriate.

246. Conjuctions such as "et" are normally deployed to facilitate coherence. Their illogical use, according to Adorno in his Notes to Literature, undermines the communicative use of language to underline its material, alterior dimension, that is, a language emancipated from the coercion of logical concepts. Although Adorno does not discuss this aspect of the Missa, he does mention the musical equivalent of the illogical conjunction in Mahler: "Among the idiosyncratic features of Mahler's use of rhythm we find isolated notes . . in which the flow of the music comes to a halt or rather is suspended in mid-air"; such notes resist "non-violently the essentially dramatic onward thrust of the symphony." In this light, the Missa's paratactic expression on "et" could be seen to offer a nonviolent means of resistance to the formal coercion that Adorno hears in the Credo. See Adorno, "Mahler," in Quasi una Fantasia: Essays on Modern Music, 104-5; and idem, "On Epic Naiveté," in Notes to Literature 1:28; also see Nicholsen, Exact Imagination, 79-84.

247. The "exceptions" that Adorno singles out from the Missa are all short passages in which Christ is portrayed in his humanity: the "Et homo factus est" of the Credo, the Benedictus, and parts of the Agnus Dei and Dona Nobis Pacem. See Adorno, Beethoven, 147 and 149.

248. Ibid., 147.

249. English Language Liturgical Commission Translation of the Nicene Creed.

250. See Levy, “'Ma però beschleunigend,'” 147.

251. Such a possibility chimes with Wilfrid Mellers's claim in Beethoven and the Voice of God that "Beethoven's 'religious' experiences [were expressed as] . . . a search for a Song that has long 
Example 8 Beethoven, Missa solemnis, Credo, mm. 178-181

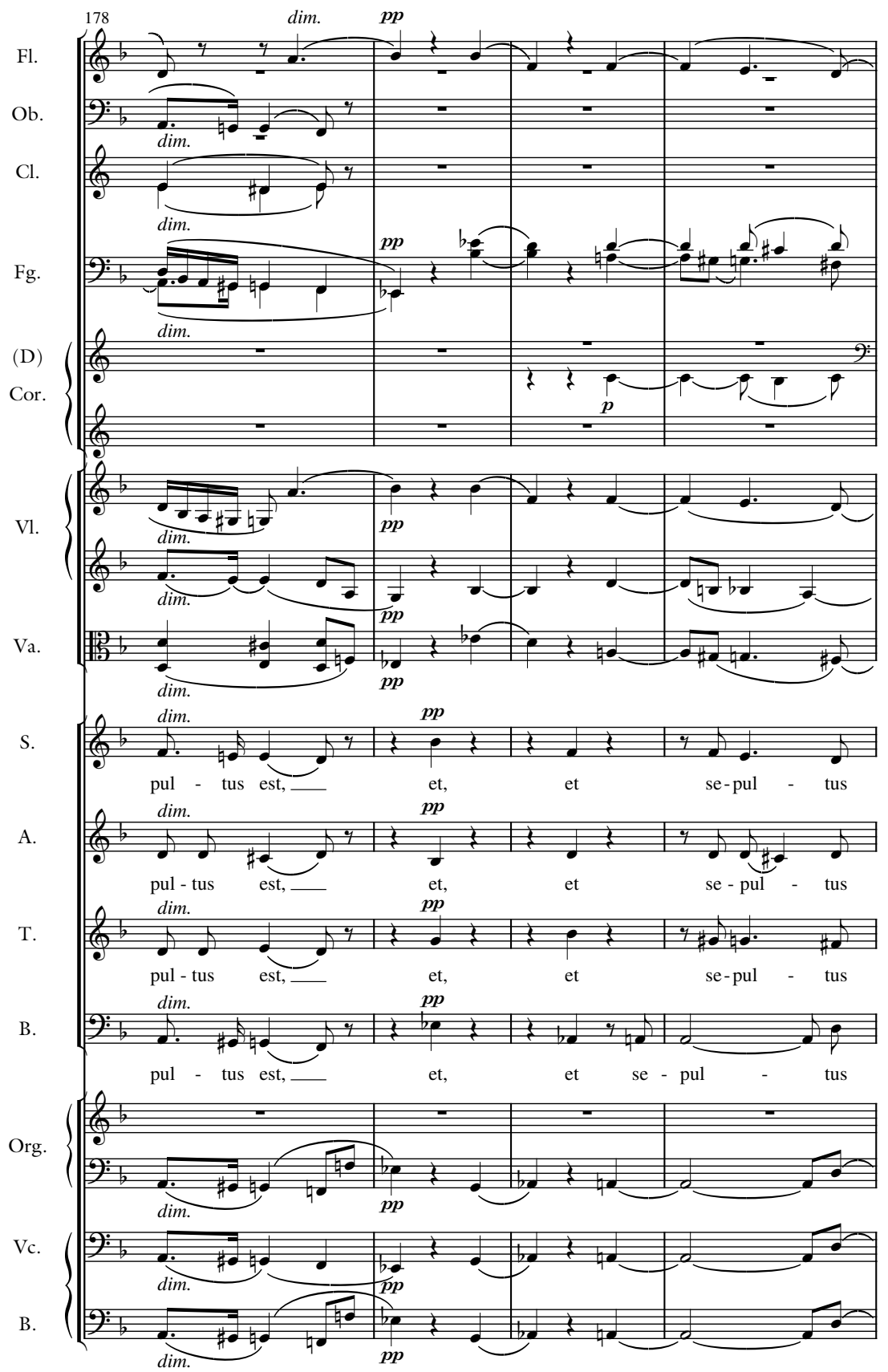


Rather, as Kierkegaard insists, Christ incognito is an oblique communication that reveals more about us than Christ. ${ }^{252}$ Or, as Adorno puts it, the music "understands us" and "speaks to us." 253 Anonymity is a condition of being seen by the Other, a "gift of sight" without any recognition.

\section{Facing Redemption}

The face. The eyes. The gaze. These optic ciphers that encrypt the Other are strangely musical: they form "the sonority" of the face, as Lévinas puts it; or, in Adorno's words, they indicate music's "gift of sight." This sounding optics, as we have seen, suggests a certain invisibility, a delay or distance that safeguards the alterity of the Other from the instrumentalized vision of the modern subject. A work, such as the Cavatina, makes the sonorous gaze thematic by giving time for its disclosure. But what inspires this audio-visual fusion in the philosophy of alterity is the non-representational aspect of music itself; the vacant sign already contains the potential for this relation. Ironically, the "otherness" of the sign is predicated on the blankness (invisibility), emptiness (distance), and inaccessibility (delay) that constitutes the blindness of the monad. Sound, as the invisible vision for alterity, is grounded in the discourse of ab-

been lost or forgotten" (444), a divine voice found at the heart of the Missa solemnis. Although Mellers's "Song" is neither a Christological nor a covert one and tends toward divine timelessness, there is a degree of truth in his somewhat literal and seemingly unsupported claims. What is clear is that the Missa solemnis provided Beethoven with a religious vocabulary that surfaces in various late works. The exact sound for God is polarized between the lyricism which Meller identifies as "Song" and William Kinderman's "symbol for the deity" - a stratospheric, high-volume sonority that represents a Kantian deity ensconced above the starry heavens. But this merely reflects the range of Beethoven's religious vocabulary in the Missa. Other "divine sonorities" not only include the suffering of Christ in the Credo that finds its way into the Arioso Dolente of Opus 110, the variations of Opus 111, the Cavatina of Opus 130, and arguably the "gapped" subject of the Grosse Fuge, but also the blessing of Christ in the Benedictus, which recurs in slow movement of Opus 127 (as Kinderman himself points out), and the mocking of Christ in the fugato of the "Dona Nobis Pacem," which is taken up in the Grosse Fuge. The latter two Christological topics are also evident in the last two movements of the Hammerklavier; although this work precedes the Missa, Beethoven described the sonata as a "prelude to my mass." See Kinderman, "Beethoven's Symbol for the Deity"; Maynard Solomon, "Intimations of the Sacred" in Late Beethoven, 198-212; Stephen Rumph, Beethoven After Napoleon: Political Romanticism in the Late Works (Berkeley: University of California Press, 2004), 35-57, 195-221; Levy, " "Ma però beschleunigend" "; Erwin Ratz, "Analysis and Hermeneutics and Their Significance for the Interpretation of Beethoven," trans. Mary Whittall, Music Analysis 3 (1984): 243-54; and Warren Kirkendale, "New Roads to Old Ideas in Beethoven's Missa Solemnis," Musical Quarterly 56 (1970): $665-701$.

252. "The God-man is the sign of contradiction," writes Kierkegaard in Practice in Christianity, 126, born to "disclose the thoughts of [our] hearts."

253. Adorno, Beethoven, xi. 
solute music; the pure sign that once intimated the infinity of the romantic ego now resonates with the infinity of the Other. ${ }^{254}$

It appears that the Other is simply the flip side of the monad. After all, the early romantics were the first to champion the empty sign as "Other"albeit the self-as-other. Music gave access to a subject that Kant had made famously inaccessible to knowledge. It was a non-representational sign for a non-representable self whose invisibility was merely a cipher for the subject's noumenal existence. Given this self-reflexive function, it takes only a slight discursive tweak to flip the perspective of the empty sign from the monadic subject to a vision of alterity. But such inversions do not happen in the abstract: the non-representational sign requires cultural labour to make concrete the theoretical possibilities it harbors. The particular matters. The discursive meanings that fluctuate around music's empty sign exist only through works that activate their potential. If the Eroica Symphony, for example, projects the empty sign as a heroic monad, the Cavatina can alter that sign to reflect in its void the aura of an Other. By attending to the music's details, the very sign whose blankness had all but deified the subject becomes the condition for the disclosure of an inaccessible Other made in the image of Christ. In Marion's terms, the idol becomes an icon. ${ }^{255}$

However, the Other is not simply an inversion of the subject-object relation, as if it had turned the tables on the subject, demanding a unilateral submission to its alterity. Indeed, if the Cavatina evokes the gaze of Christ, then the face of the Other is not merely a victim who demands a response but the very Gift that breaks the economy of the Self. It is the catalyst for the metanoia of the monad-a radical transformation of the ego's self-existence. In such instances, the face of alterity is not only the law that founds the subject with its a priori gaze, as Lévinas claims, ${ }^{256}$ it is a work of grace- a gift. In fact, grace precedes law, for Christ-in-the-Other implies that there is a for-giving before any giving, a debt to love before any price of love is demanded, a divine displacement before any replacement of our "Da-sein." 257 In this sense, the

254. See Lévinas, Alterity and Transcendence, 30 and 75-76.

255. For Jean-Luc Marion an idol may communicate something about God but God is barred from challenging that representation by the human gaze; with an icon, on the other hand, one is subject to God's gaze. These ideas are discussed theologically in his God Without Being, trans. Thomas A. Carlson (Chicago: University of Chicago Press, 1991), 7-22; and phenomenologically in idem, Being Given, 199-234.

256. Lévinasian ethics still bear traces of the sublime law: the "infinite alterity" of the face summons the subject to an "infinite responsibility." It is a unilateral effort that presupposes a subject that can will itself to act, turning Lévinas's asymmetrical "I-thou" relation into a strangely nonrelational response that can reduce the idealized other to eternal victimhood. The issue, then, is one of agency and grace, that is, whether the self can execute the ethics demanded of the Other, and whether the Other is merely a given or a gift to be reciprocated. For a theological critique of Lévinas's position see John Milbank, Being Reconciled: Ontology and Pardon (London: Routledge, 2003), 138-61.

257. 1 John 4:19: "We love because he first loved us" (NIV). 
Other already gives what is demanded of the Self. It is not merely the condition for a reciprocal relation, but the very agent of reciprocation itself-the grace that inspires the subject to receive the stranger. To borrow Marion's terminology, those who "give way" to grace become "gifted," 258 receiving a talent for love that might thaw the "coldness of the societal monad." Beethoven's "gift of sight," then, is the grace that enables us to see the invisible aura of humanity; it is a seeing that gives sight. It is in this sense that the eyes that open in the closing chord of the Cavatina "understand us," transforming the moment of tonal stasis into one of expressive ek-stasis. Perhaps the intensity of this gaze is conjured up by the suspended crescendo that reaches out beyond the final bar in a gesture of open embrace; or maybe it is in the inconclusiveness of the final chord where the upper voice lingers on the mediant $(G)$, as if melodically it were holding its breath for an answer. Either way, by recalling the central dislocation at the moment of resolution, the Cavatina gestures to the possibility of reconciliation, giving time for a returning glance in the drawn-out breath of its cadence. To come back to Adorno's phrase: "It . . . waits with sad eyes for us to answer." Perhaps, when writing these words, Adorno was aware of Beethoven's confession to Karl Holz that the Cavatina was composed "with tears of sadness in his eyes." ${ }^{259}$ Unfortunately, Beethoven did not divulge the cause of these tears, and Adorno, of course, refuses to give the answer they seek. But neither the cause nor the desired answer are a secret. They are already disclosed in the eyes of the Cavatina; in recalling the humiliation of the beklemmt section, the final chord reflects the humility necessary for reciprocation, for it is only in the place of exposure that one is open to love, open to give, open to being human..$^{260}$

But it is precisely for this reason that gifts are as dangerous as they are conciliatory; the relation they imply is one of mutual vulnerability, an exposure that the powers of contracts and rights are meant to cover up in the name of the law. On hearing the final chord of the Cavatina, one wants to give way to its radiance and give time for its beauty to resonate. The crescendo that suddenly disappears and the $\mathrm{G}$ that holds its breath seem to require an infinite suspension of the instant. But, as the Grosse Fuge that originally followed the Cavatina demonstrates, gifts, because they are free, need not be received. The $\mathrm{G}$ that closes the Cavatina is seized by the fugue with a violence that seems to snuff out its final breath. Moreover, the asthmatic stutterings of the beklemmt section are mimicked in the opening "gapped" fugue (mm. 26-158); in fact, they are mangled, since the fugal process is one in which the gaps are eventually squeezed out, compressing the subject to the point of asphyxiation (Ex. 9a and b). The fugue's formal law of freedom ("tânto libre," as Beethoven de-

258. See Marion, Being Given, 248-319. The debt of love is always a gift in that it cannot by definition be love if it is paid back; it can only be passed on.

259. Lenz, Beethoven: Eine Kunststudie, vol. 5, pt. 4, p. 217.

260. Lévinas, Is It Righteous to Be? 208. Also see Butler, Giving an Account of Oneself, 100102. 
Example 9 Beethoven, Grosse Fuge, Op. 133, "gapped" subject: (a) with gaps (mm. 26-30); (b) without (mm. 139-41)

(a)

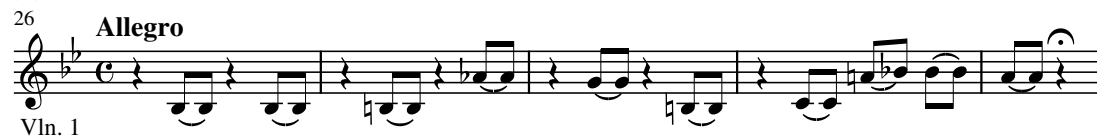

(b)

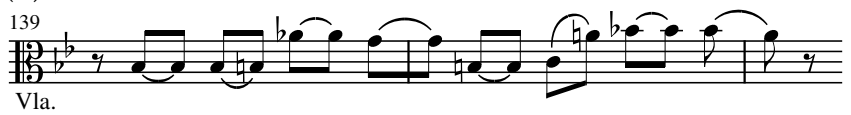

scribes it in the score) does not give time for the material to disclose itself but seizes it with a breath-taking virtuosity. It differs from the compression of the heroic Augenblick only in that the violence is no longer masked by the purity of the form. Although the gapped fugue hardly leaves its tonic $(\mathrm{B} b)$, the subject and countersubject suggest divergent harmonic planes that generate a dissonant momentum within the tonic texture; ${ }^{261}$ this contrapuntal friction is matched by a rhythmic dislocation that eventually buckles the position of the downbeat (mm. 129-152). After 128 measures of unremitting volume ( forte, fortissimo, sforzando) and excruciating dissonance, the fugue loses its tonal and metrical orientation and slams, without warning, into a wall of G-flat major (mm. 158-159). Such destruction cannot be bypassed as the mere product of intellectual abstraction. As with the Cavatina, Beethoven is speaking through the breakdown of technique, but this time the Other is not seen from the vantage of hospitality, but hostility. From his investigation of the sketches, Levy suggests that Beethoven conceived this fugue as an allegory of the crucifixion. In particular, the gapped subject, with its tied eighth note notation (suspiratio) and jagged leaps (saltus duriusculus), refers to Baroque figures associated with the Passion through their evocation of pain, anguish, and suffering. ${ }^{262}$ This allegory is hardly surprising, given the allusion to the Missa solemnis in the Cavatina. But unlike its Baroque counterparts, the rhetorical language of the Grosse Fuge is stripped of its communicative dimension: the sign "saltus duriusculus," for example, does not merely denote its signified "pain" in order to express or picture the emotion; rather the sign wants to be "pain" in the

261. See Spitzer, Music as Philosophy, 101.

262. See Levy, "'Ma però beschleunigend.' " Levy's work takes up a theme explored by Erich Schenk in "Barock bei Beethoven," in Beethoven und die Gegenwart: Festschrift Ludwig Schiedermair zum 60. Geburtstag, ed. Arnold Schmitz, 177-219 (Berlin and Bonn: Dümmler, 1937); Schenk suggests that Beethoven's epigrammatic use of Baroque figures in some late works symbolizes states of suffering, deprivation, and death. This purely musicological study resonates with Adorno's philosophical speculations on the late style, which is informed by Benjamin's thesis on the Baroque Trauerspiel (mourning-play). The debris of the Baroque, which Levy and Schenk unearth, is a counterpart to Benjamin's allegorical figures of death. See Walter Benjamin, The Origin of German Tragic Drama, trans. John Osborne (London: NLB, 1977). 
very materiality of its musical figuration; and it does so by meting out violence on the rhetorical act itself, rendering the figures grotesquely opaque. The visceral and muscular exertions demanded in the execution of these figures reveal the very effort of form in the act of purification: this is form seen from its boundaries of exclusion, policing its margins by pain. Indeed, Stravinsky admired the Grosse Fuge precisely for the process of brutal abstraction that presages the formalism of his own century; what he describes as "pure interval music" is the fugue's violent distillation of its musical essence. ${ }^{263}$

Strangely, the Cavatina and the Grosse Fuge share similar structural dislocations. However, such disruptions in themselves cannot function as generic markers for meaning. As with the empty sign, how the concrete particular activates the structure makes all the difference to what appears to be the same. Indeed, the juxtaposition of the Cavatina and the Grosse Fuge magnifies the minute slippage between the structures of love and violence that humanity all too easily confuses. ${ }^{264}$ And perhaps it is the truth of this confusion that was too close for comfort at the first performance of Opus 130. The fugue was such a "Babelic" offence that Beethoven was persuaded to ostracize it from the quartet and replace it with an "alternative" finale. 265 The question today, however, is no longer hidden behind the aesthetic smokescreen of the first critics since the fugue's artistic integrity is no longer in doubt; the issue is now an ethical one. Structurally, Beethoven has tied the fugue to the Cavatina by interconnecting the Gs that end the song and initiate the finale. It is as if Beethoven wanted the audience to think about the juxtaposition, not to implicate the listener but to make conscious what would otherwise remain inarticulate within the subject. Although the juxtaposition seemed like nonsense to the first audience, theologically it makes sense; it is "the formal law of freedom" unmasked by the face of the Other. ${ }^{266}$ As Lévinas suggests: the face of the Other does not merely command without force, it also tempts the first crime. Murder is the normative reaction to "the imponderably delicate aura of the Other." And if, as suggested, the Cavatina evokes the suffering gaze of

263. Igor Stravinsky and Robert Craft, Dialogues and a Diary (London: Faber, 1968), 124. On Stravinsky's formalism see Richard Taruskin, "A Myth of the Twentieth Century: The Rite of Spring, the Tradition of the New, and 'The Music Itself,'" Modernism/Modernity 2 (1995): $1-26$.

264. See note 157 .

265. The term "Babel" was actually leveled at the Grosse Fuge. See Anton Felix Schindler, Beethoven as I Knew Him, ed. Donald W. MacArdle, trans. Constance S. Jolly (London: Faber, 1966), 307.

266. It is apt that both Paul Bekker and J. W. N. Sullivan interpret the Grosse Fuge as a solution to the question of "freedom and necessity [i.e., law]." Sullivan hears in the fugue the necessity of suffering as a gift to be received. In other words, the formal law of freedom is the freedom to accept the law that form imposes. See Paul Bekker, Beethoven, trans. M. M. Bozman (London: Dent, 1925), 332; and J. W. N. Sullivan, Beethoven: His Spiritual Development (London: Jonathan Cape, 1927), 228-30. 
Christ, then perhaps Adorno is right in assigning the "possibility of pogroms ... [to] the moment when the gaze of a fatally wounded animal falls on a human being. The defiance with which he repels this gaze-'after all, it's only an animal'-reappears irresistibly in cruelties done to human beings, the perpetrators having again and again to reassure themselves that it is only an animal." "267 Our pathological condition of fear means that the truly human must be purged in order to maintain the sovereignty of the Self. The Grosse Fuge registers the automatic need to avert the gaze with an aggression that borders on hubris. Having wrenched the $\mathrm{G}$ from the previous cadence, Beethoven cranks the music chromatically upwards as if the fugue were turning away from the eyes of the Cavatina. Indeed, Richard Kramer hears this "horrific G" between the two movements as a "narrative voice" that "brazenly repudiates" the Cavatina as mere fantasy, "a voice that, in a structural sense, can be said to supersede the voice that sings the Cavatina." This voice is an outside force that takes narrative control of the Other. ${ }^{268}$ So in one sense, the Grosse Fuge triumphs by absorbing the Other into itself. But its sheer force is so disproportionate to the weakness of the gaze that its heroic antics appear empty. The fugue is an over-reaction, for there is no force to react against, no cause for Promethean rebellion, no ground for the sublime. In the fraught question concerning the true finale of this quartet, one can assert with many commentators that the Cavatina and the Grosse Fuge are inextricable bound; however, it is not the overwhelming power of the fugue that is the source of the problem but the Cavatina. In the end, the Grosse Fuge cannot stand fast against it. It cannot demythologize the gaze. The fugue's self-destructive aggression betrays the ineradicable stain of the Other which, without standing firm, has shaken the very core of monadic purity. The transient turns out to be a permanent irritation. Its infinite patience is "an absolute resistance to possession."269 Thus the sad eyes that peer out of the Cavatina with its fragile and exposed gaze are offered as the most dangerous gift of all, for to face this music is to face up to redemption.

267. Adorno, Minima Moralia, 105. For Agamben, the homo sacer is the embodiment of the logic of exception and exclusion that is the very foundation of Roman sovereignty; for power to maintain its grip, it must ultimately reduce even what it is self-bound to protect to some quasianimal status, a form of bare life that can be killed indifferently. Since the homo sacer cannot be murdered, executed, or sacrificed under Roman law, he is the illegal exception on which the legality of sovereignty depends. John Milbank in Being Reconciled, 90-104, extends this idea to Christ; his death is not dignified, like that of a martyr for a cause; rather "he died the death which any of us, under sovereign authority, in exceptional circumstances which always prove the rule, may possibly die. . . . He died the death of us all" (96-97). In this sense, the G that connects the Cavatina to the Grosse Fuge exposes in theological terms the horrific logic of homo sacer.

268. Kramer, "Between Cavatina and Overture: Opus 130 and the Voices of Narrative," 181 and 184 .

269. Lévinas, Difficult Freedom, 8. 


\section{Works Cited}

Adorno, Theodor W. Aesthetic Theory. Edited by Gretel Adorno and Rolf Tiedemann. Translated by R. Hullot-Kentor. Minneapolis: University of Minnesota Press, 1997. - Beethoven: The Philosophy of Music. Edited by Rolf Tiedemann. Translated by Edmund Jephcott. Cambridge: Polity Press, 1998.

- "Education After Auschwitz." In Critical Models: Interventions and Catchwords, translated by Henry W. Pickford. European Perspectives. New York: Columbia University Press, 1998, 191-204.

- Introduction to the Sociology of Music. Translated by E. B. Ashton. New York: Seabury Press, 1976.

- Kierkegaard: Construction of the Aesthetic. Edited and translated by Robert Hullot-Kentor. Theory and History of Literature 61. Minneapolis: University of Minnesota Press, 1989.

—. "Mahler." In Quasi una Fantasia: Essays on Modern Music, 81-110.

—. Minima Moralia: Reflections from Damaged Life. Translated by E. F. N. Jephcott. London: Verso, 2002.

- Moments musicaux. In Musikalische Schriften IV. Vol. 17 of Gesammelte Schriften, edited by Rolf Tiedemann. Frankfurt am Main: Suhrkamp, 1982, 8-161.

—. Negative Dialectics. Translated by E. B. Ashton. London: Routledge, 1973.

- Notes to Literature. Edited by Rolf Tiedemann. Translated by Shierry Weber Nicholsen. European Perspectives. 2 vols. New York: Columbia University Press, 1991-92.

—_. "On Epic Naiveté." In Notes to Literature 1:24-29.

- Philosophy of Modern Music. Translated by Anne G. Mitchell and Wesley V. Blomster. London: Sheed and Ward, 2003.

—_. "Presuppositions," In Notes to Literature 2:95-108.

- Quasi una Fantasia: Essays on Modern Music. Translated by Rodney Livingstone. London: Verso, 1992.

- . "Schöne Stellen." In Musikalische Schriften V. Vol. 18 of Gesammelte Schriften. edited by Rolf Tiedemann. Frankfurt am Main: Suhrkamp, 1984, 695-718.

—. "Schwierigkeiten." In Impromptus: Zweite Folge neu gedruckter musikalischer Aufsätze, Musikalische Schriften IV. Vol. 17 of Gesammelte Schriften, edited by Rolf Tiedemann. Frankfurt am Main: Suhrkamp Verlag, 1982, 253-91.

—. "Stravinsky: A Dialectical Portrait." In Quasi una Fantasia: Essays on Modern Music, 145-78. - "Theses Upon Art and Religion Today." In Notes to Literature 2:292-98.

Adorno, Theodor W., and Max Horkheimer. Dialectic of Enlightenment. Translated by John Cumming. London: Verso, 1999.

Agamben, Giorgio. Homo Sacer: Sovereign Power and Bare Life. Translated by Daniel Heller-Roazen. Stanford, CA: Stanford University Press, 1998.

Beethoven, Ludwig van. Ludwig van Beethovens Konversationshefte. Edited by KarlHeinz Köhler et al. 11 vols. Leipzig: VEB Deutscher Verlag für Musik, 1968-.

—. Sämtliche Briefe. Edited by Emerich Kastner. Revised by Julius Knapp. Tutzing: Hans Schneider, 1975.

Bekker, Paul. Beethoven. Translated by M. M. Bozman. London: Dent, 1925.

Benjamin, Walter. Illuminations. Edited by Hannah Arendt. Translated by Harry Zohn. London: Fontana Press, 1968. 
"Little History of Photography." Translated by Edmund Jephcott and Kingsley Shorter. In Selected Writings, edited by Michael Jennings et al., translated by Rodney Livingstone et al. 4 vols. Cambridge, MA: Harvard University Press, 1996-2003, 2:507-30.

—. "On Some Motifs in Baudelaire." In Illuminations, 152-96.

- The Origin of German Tragic Drama. Translated by John Osborne. London: NLB, 1977.

211-44.

Bergson, Henri. Matter and Memory. Translated by Nancy Margaret Paul and W. Scott Palmer. New York: Zone Books, 2004.

Bernstein, J. M. Adorno: Disenchantment and Ethics. Modern European Philosophy. Cambridge: Cambridge University Press, 2001.

Brendel, Alfred. Alfred Brendel on Music. Chicago: A Cappella Books, 2001.

Broyles, Michael. The Emergence and Evolution of Beethoven's Heroic Style. New York: Excelsior, 1987.

Buch, Esteban. Beethoven's Ninth: A Political History. Translated by Richard Miller. Chicago: University of Chicago Press, 2003.

Burgess, Anthony. A Clockwork Orange. New York and London: Norton, 1987.

Burnham, Scott. Beethoven Hero. Princeton, NJ: Princeton University Press, 1995.

Butler, Judith. Giving an Account of Oneself. New York: Fordham University Press, 2005.

Carbone, Mauro. The Thinking of the Sensible: Merleau-Ponty's A-Philosophy. Northwestern University Studies in Phenomenology and Existential Philosophy. Evanston, IL: Northwestern University Press, 2004.

Chua, Daniel K. L. Absolute Music and the Construction of Meaning. New Perspectives in Music History and Criticism. Cambridge: Cambridge University Press, 1999.

$\rightarrow-$. "Adorno's Metaphysics of Mourning: Beethoven's Farewell to Adorno." Musical Quarterly 87 (2004): 523-45.

- "Drifting: The Dialectics of Adorno's Philosophy of New Music." In Apparitions: New Perspectives on Adorno and Twentieth-Century Music, edited by Berthold Hoeckner, 1-17. Studies in Contemporary Music and Culture. New York and London: Routledge, 2006.

—. The "Galitzin" Quartets of Beethoven: Opp. 127, 132, 130. Princeton, NJ: Princeton University Press, 1995.

— . "The Promise of Nothing: The Dialectic of Freedom in Adorno's Beethoven." Beethoven Forum 12 (2005): 13-35.

$\rightarrow$ _ Untimely Reflections on Operatic Echoes: How Sound Travels in Monteverdi's L'Orfeo and Beethoven's Fidelio with a Short Instrumental Interlude." Opera Quarterly 21 (2005): 573-96.

Comini, Alessandra. The Changing Image of Beethoven: A Study in Mythmaking. New York: Rizzoli, 1987.

—. "The Visual Beethoven: Whence, Why and Whither the Scowl?" In Beethoven and His World, edited by Scott Burnham and Michael P. Steinberg, 286-312. Princeton, NJ: Princeton University Press, 2000.

Cooper, Barry. Beethoven. The Master Musicians. Oxford: Oxford University Press, 2000.

Cox, Arnie. "The Mimetic Hypothesis and Embodied Musical Meaning." Musicae Scientiae 5 (2001): 195-212. 
Cumming, Naomi. The Sonic Self: Musical Subjectivity and Signification. Advances in Semiotics. Bloomington and Indianapolis: Indiana University Press, 2000.

$\rightarrow$ _ . "The Subjectivities of 'Erbarme Dich.' " Music Analysis 16 (1997): 5-44.

Derrida, Jacques. Given Time: I. Counterfeit Money. Translated by Peggy Kamuf. Chicago: University of Chicago Press, 1992.

- Of Hospitality: Anne Dufourmantelle Invites Jacques Derrida to Respond. Translated by Rachel Bowlby. Cultural Memory in the Present. Stanford, CA: Stanford University Press, 2000.

Fichte, J. G. Nachgelassene Schriften 1800-1803. Part 2 of Gesamtausgabe der Bayerischen Akademie der Wissenschaften, edited by Reinhard Lauth and Hans Jakob. Stuttgart-Bad Cannstatt: Frommann-Holzboog, 1962-.

Fink, Robert. "Beethoven Antihero: Sex, Violence, and the Aesthetics of Failure, or, Listening to the Ninth Symphony as Postmodern Sublime." In Beyond Structural Listening? Postmodern Modes of Hearing, edited by Andrew Dell'Antonio, 109-53. Berkeley: University of California Press, 2004.

Floros, Constantin. Beethovens Eroica und Prometheus-Musik. Veröffenlichungen zur Musikforschung 3. Wilhemshaven: Heinrichshofen, 1978.

Gadamer, Hans-Georg. "Man and Language." In Philosophical Hermeneutics, translated and edited by David E. Linge. Berkeley: University of California Press, 1976, 59-68.

Goud, Johan F. "Wat men van zichzelf eist, eist men van een heilige: Een gesprek met Emmanuel Lévinas." Ter herkenning 11 (1983): 85-86.

Gunton, Colin E. The One, the Three and the Many: God, Creation and the Culture of Modernity. Cambridge: Cambridge University Press, 1993.

Habermas, Jürgen. The Structural Transformation of the Public Sphere: An Inquiry into a Category of Bourgeois Society. Translated by Thomas Burger. Studies in Contemporary German Social Thought. Cambridge MA: MIT Press, 1991.

$\rightarrow$ Hansen, Miriam Bratu. "Benjamin's Aura." Critical Inquiry 34 (2008): 336-75.

Hanslick, Eduard. The Beautiful in Music. Edited by Morris Weitz. Translated by Gustav Cohen. Library of Liberal Arts 45. New York: Liberal Arts Press, 1957.

Hoeckner, Berthold. Programming the Absolute: Nineteenth-Century German Music and the Hermeneutics of the Moment. Princeton, NJ: Princeton University Press, 2002.

Hoffmann, E. T. A. "Beethoven's Instrumental Music," from Kreisleriana. Translated in E. T. A. Hoffmann's Musical Writings: "Kreisleriana," "The Poet and the Composer, Music Criticism," edited by David Charlton, translated by Martyn Clarke, 96-103. Cambridge Readings in the Literature of Music. Cambridge: Cambridge University Press, 1989.

—. "Review of Beethoven's Fifth Symphony." Allgemeine musikalische Zeitung 12 (4 and 11 July 1810): cols. 630-42 and 652-59. Translated, in a slightly different version, in E. T. A. Hoffmann's Musical Writings: "Kreisleriana," "The Poet and the Composer, Music Criticism,” edited by David Charlton, translated by Martyn Clarke, 234-51. Cambridge Readings in the Literature of Music. Cambridge: Cambridge University Press, 1989.

$\rightarrow$ Hyer, Brian. Review of Beethoven Hero by Scott Burnham. Music Theory Spectrum 20 (1998): 121-36.

Jarvis, Simon. Adorno: A Critical Introduction. New York: Routledge, 1998.

Jay, Martin. Downcast Eyes: The Denigration of Vision in Twentieth-Century French Thought. Berkeley: University of California Press, 1993. 
Kant, Immanuel. "An Answer to the Question: What is Enlightenment?” In Perpetual Peace and Other Essays on Politics, History, and Morals, translated by Ted Humphrey. Indianapolis: Hackett, 1983, 41-48.

- Critique of Judgement. Translated by James Creed Meredith. Oxford: Clarendon Press, 1969.

Kerman, Joseph. The Beethoven Quartets. Oxford: Oxford University Press, 1967.

Kierkegaard, Søren. Practice in Christianity. Translated by Howard V. Hong and Edna H. Hong. Princeton, NJ: Princeton University Press, 1991.

Kinderman, William. Beethoven. Oxford: Oxford University Press, 1995.

_ "Beethoven's Symbol for the Deity in the Missa solemnis and the Ninth Symphony." 19th-Century Music 9 (1985): 102-18.

$\rightarrow$ Kirkendale, Warren. "New Roads to Old Ideas in Beethoven's Missa Solemnis." Musical Quarterly 56 (1970): 665-701.

Korsyn, Kevin. "Schenker and Kantian Epistemology." Theoria 3 (1988): 1-58.

Kramer, Richard. "Between Cavatina and Overture: Opus 130 and the Voices of Narrative." Beethoven Forum 1 (1992): 165-89.

Leibniz, Gottfried. Monadology. In Discourse on Metaphysics, Correspondence with Arnauld, and Monadology, translated by George Montgomery, 251-72. LaSalle, IL: Open Court Publishing Company, 1993.

Lenz, Wilhelm von. Beethoven: Eine Kunststudie. 6 pts. in 5 vols. Cassel: Balde; and Hamburg: Hoffmann \& Campe, 1855-60.

Lévinas, Emmanuel. Alterity and Transcendence. Translated by Michael B. Smith. London: Athlone Press, 1999.

—. Collected Philosophical Papers. Translated by Alphonso Lingis. Pittsburgh: Duquesne University Press, 1998.

_. "Diachrony and Representation." In Entre nous, 159-78.

. Difficult Freedom: Essays on Judaism. Translated by Seán Hand. Baltimore: Johns Hopkins University Press, 1990.

- Entre nous: On Thinking-of-the-Other. Translated by Michael B. Smith and Barbara Harshav. European Perspectives. New York: Columbia University Press, 1998.

\section{$133-54$.}

—. Is It Righteous to Be? Interviews with Emmanuel Lévinas. Edited by Jill Robbins. Meridian. Stanford, CA: Stanford University Press, 2001.

—. "Language and Proximity." In Collected Philosophical Papers, 109-26.

_. "A Man-God?" In Entre nous, 53-60.

_- "Nonintentional Consciousness." In Entre nous, 123-32.

- Otherwise Than Being, or, Beyond Essence. Translated by Alphonso Lingis. Pittsburgh: Duquesne University Press, 1998.

- "The Philosophical Determination of the Idea of Culture." In Entre nous, 179-88.

—. "Reality and Its Shadow." In The Lévinas Reader, edited by Seán Hand. Oxford: Blackwell, 1989, 129-43.

- Time and the Other, and Additional Essays. Translated by Richard A. Cohen. Pittsburgh: Duquesne University Press, 1987.

- Totality and Infinity: An Essay on Exteriority. Translated by Alphonso Lingis.

Pittsburgh: Duquesne University Press, 1969. 
. "Totality and Infinity: An Essay on Exteriority. Preface to the German Edition." In Entre nous, 197-200.

—. "La trace de l'autre" (1949). In En découvrant l'existence avec Husserl et Heidegger. Paris: Vrin, 1970 (first edition, 1949), 187-202.

_. "Useless Suffering." In Entre nous, 91-102.

Levy, David B. “"Ma però beschleunigend': Notation and Meaning in Ops. 133/ 134." Beethoven Forum 14 (2007): 129-49.

Lockwood, Lewis. Beethoven: Studies in the Creative Process. Cambridge, MA: Harvard University Press, 1992.

- "Beethoven, Florestan, and the Varieties of Heroism." In Beethoven and His World, edited by Scott Burnham and Michael P. Steinberg, 27-47. Princeton, NJ: Princeton University Press, 2000.

Lyotard, Jean-François. "The Sign of History.” In Post-Structuralism and the Question of History, edited by Derek Attridge, Geoff Bennington, and Robert Young, 162-80. Cambridge: Cambridge University Press, 1987.

Marion, Jean-Luc. Being Given: Toward a Phenomenology of Givenness. Translated by Jeffrey L. Kosky. Stanford, CA: Stanford University Press, 2002.

—. "The Final Appeal of the Subject." In The Religious, edited by John D. Caputo, 131-44. Blackwell Readings in Continental Philosophy. Oxford: Blackwell, 2002.

—. God Without Being. Translated by Thomas A. Carlson. Religion and Postmodernism. Chicago: University of Chicago Press, 1991.

Mathew, Nicholas. "Beethoven and His Others: Criticism, Difference, and the Composer's Many Voices." Beethoven Forum 13 (2006): 148-87.

McClary, Susan. Feminine Endings: Music, Gender, and Sexuality. Minneapolis: University of Minnesota Press, 1991.

Mellers, Wilfrid. Beethoven and the Voice of God. London: Faber, 1983.

Merleau-Ponty, Maurice. "Eye and Mind." In The Merleau-Ponty Aesthetics Reader: Philosophy and Painting, edited by Galen Johnson, translations edited by Michael B. Smith. Northwestern University Studies in Phenomenology \& Existential Philosophy. Evanston, IL: Northwestern University Press, 1993, 121-49.

- "The Intertwining - the Chiasm." In The Visible and the Invisible, edited by Claude Lefort, translated by Alphonso Lingis. Northwestern University Studies in Phenomenology \& Existential Philosophy. Evanston, IL: Northwestern University Press, 1968, 130-55.

- Nature: Course Notes from the Collège de France. Compiled and with other notes by Dominique Séglard. Translated by Robert Vallier. Northwestern University Studies in Phenomenology \& Existential Philosophy. Evanston, IL: Northwestern University Press, 2003.

- Phenomenology of Perception. Translated by Colin Smith. International Library of Philosophy and Scientific Method. London: Routledge and Kegan Paul, 1962.

Milbank, John. "Beauty and the Soul." In Milbank, Graham Ward, and Edith Wyschogood, Theological Perspectives on God and Beanty, 1-34. Rockwell Lecture Series. Harrisburg, PA: Trinity Press International, 2003.

- Being Reconciled: Ontology and Pardon. Radical Orthodoxy Series. London: Routledge, 2003.

Moltmann, Jürgen. Theology of Hope: On the Ground and the Implications of a Christian Eschatology. Translated by James W. Leitch. Minneapolis: Fortress Press, 1993. 
Nicholsen, Shierry Weber. Exact Imagination, Late Work: On Adorno's Aesthetics. Studies in Contemporary German Social Thought. Cambridge, MA: MIT Press, 1997.

Nietzsche, Friedrich. "The Birth of Tragedy" and "The Case of Wagner." Translated by Walter Kaufmann. New York: Random House, 1967.

$\rightarrow$ Nirenberg, David. "The Politics of Love and Its Enemies." Critical Inquiry 33 (2007): 573-605.

Norris, Christopher. What's Wrong with Postmodernism: Critical Theory and the Ends of Philosophy. Parallax. Baltimore: Johns Hopkins University Press, 1990.

Osthoff, Wolfgang. "Mozarts Cavatinen und ihre Tradition." In Helmut Osthoff zu seinem siebzigsten Geburtstag, edited by Ursula Aarburg and Peter Cahn, 139-77. Frankfurter Musikhistoriche Studien. Tutzing: Hans Schneider, 1969.

Ottenberg, Hans-Günter. Carl Philipp Emanuel Bach. Translated by P. J. Whitmore. Oxford: Oxford University Press, 1987.

Outram, Dorinda. The Body and the French Revolution: Sex, Class, and Political Culture. New Haven, CT: Yale University Press, 1989.

Platen, Emil. "Zeitgenössische Hinweise zur Aufführungspraxis der letzten Streichquartette Beethovens." In Beiträge '76-78: Beethoven-Kolloquium 1977; Dokumentation und Aufführungspraxis, edited by Rudolf Klein, 100-107. Kassel, Bärenreiter, 1978.

Proust, Marcel. Swann's Way. Part 1 of In Search of Lost Time. Translated by C. K. Scott Moncrieff and Terence Kilmartin. Revised by D. J. Enright. London: Vintage, 1996.

$\rightarrow$ Ratz, Erwin. "Analysis and Hermeneutics and Their Significance for the Interpretation of Beethoven." Translated by Mary Whittall. Music Analysis 3 (1984): 243-54.

Rumph, Stephen. Beethoven After Napoleon: Political Romanticism in the Late Works. California Studies in 19th-Century Music. Berkeley: University of California Press, 2004.

Schenk, Erich. "Barock bei Beethoven." In Beethoven und die Gegenwart: Festschrift Ludwig Schiedermair zum 60. Geburtstag, edited by Arnold Schmitz, 177-291. Berlin and Bonn: Dümmler, 1937.

Schindler, Anton Felix. Beethoven as I Knew Him. Edited by Donald W. MacArdle. Translated by Constance S. Jolly. London: Faber, 1966.

Schmitt, Carl. Political Theology: Four Chapters on the Concept of Sovereignty. Translated by George Schwab. Chicago: University of Chicago Press, 2005.

Schoolman, Morton. "Toward a Politics of Darkness: Individuality and Its Politics in Adorno's Aesthetics." Political Theory 25 (1997): 57-92.

Sipe, Thomas. Beethoven: Eroica Symphony. Cambridge Music Handbooks. Cambridge: Cambridge University Press, 1998.

Solomon, Maynard. Beethoven. London: Cassell, 1977.

—. "Intimations of the Sacred." In Late Beethoven: Music, Thought, Imagination. Berkeley: University of California Press, 2003, 198-212.

- Late Beethoven: Music, Thought, Imagination. Berkeley: University of California Press, 2003.

Spitzer, Michael. Music as Philosophy: Adorno and Beethoven's Late Style. Bloomington and Indianapolis: Indiana University Press, 2006.

Steiner, George. Real Presences. Chicago: University of Chicago Press, 1989.

Straus, Joseph N. "Normalizing the Abnormal: Disability in Music and Music Theory." This Journal 59 (2006): 113-84. 
Stravinsky, Igor, and Robert Craft. Dialogues and a Diary. London: Faber, 1968.

Sullivan, J. W. N. Beethoven: His Spiritual Development. London: Jonathan Cape, 1927.

$\rightarrow$ Taruskin, Richard. "A Myth of the Twentieth Century: The Rite of Spring, the Tradition of the New, and 'The Music Itself.' " Modernism/Modernity 2, no. 2 (1995): 1-26.

Thayer, Alexander Wheelock. Thayer's Life of Beethoven. Revised by Elliot Forbes. Princeton, NJ: Princeton University Press, 1967.

Tregear, Peter. "The Ninth after 9/11." Beethoven Forum 10 (2003): 221-32.

$\rightarrow$ Tyson, Alan. "Beethoven's Heroic Phase." Musical Times 110, no. 1512 (1969): 139-41.

Vazsonyi, Nicholas. "Hegemony Through Harmony: German Identity, Schiller, and the Ninth Symphony." In Sound Matters: Essays on the Acoustics of German Culture, edited by Nora M. Alter and Lutz Koepnick, 33-48. Oxford and New York: Berghahn, 2004.

Volf, Miroslav. Exclusion and Embrace: A Theological Exploration of Identity, Otherness, and Reconciliation. Nashville: Abingdon Press, 1996.

Vries, Hent de. Minimal Theologies: Critiques of Secular Reason in Adorno and Lévinas. Translated by Geoffrey Hale. Baltimore: Johns Hopkins University Press, 2005.

Wackenroder, Wilhelm Heinrich, and Ludwig Tieck. "Symphonien." In Phantasien über die Kunst, für Freunde der Kunst, in Werke und Briefe von Wilhelm Heinrich Wackenroder. Berlin: Verlag Lambert Schneider, 1938, 133-266.

Waltham-Smith, Naomi. "Adorno's Augenblick and the Ethics of Late Beethoven." PhD diss., King's College, London, 2009.

Wellbery, David E. The Specular Moment: Goethe's Early Lyric and the Beginnings of Romanticism. Meridian. Stanford, CA: Stanford University Press, 1996.

Wellmer, Albrecht. "Adorno, Modernity, and the Sublime." In Endgames: The Irreconcilable Nature of Modernity, translated by David Midgley. Studies in Contemporary German Social Thought. Cambridge, MA: MIT Press, 2000, 155-81.

Will, Richard. The Characteristic Symphony in the Age of Haydn and Beethoven. New Perspectives in Music History and Criticism. Cambridge: Cambridge University Press, 2002.

Zizioulas, John D. Being as Communion: Studies in Personhood and the Church. Contemporary Greek Theologians 4. London: Darton, Longman and Todd, 1985.

. "Communion and Otherness." Orthodox Peace Fellowship's Occasional Paper No. 19, (1994), http://incommunion.org/articles/older-issues/communionand-otherness (accessed 16 March 2009).

— . "On Being a Person: Towards an Ontology of Personhood." In Persons, Divine and Human, edited by Christoph Schwöbel and Colin E. Gunton, 33-46. Edinburgh: T \& T Clark, 1991.

\section{Abstract}

Beethoven's Promethean image has been reenforced in recent scholarship by the idea of the "heroic." Although the escalation of the concept has been recognized as an act of selective hearing based on a handful of "heroic" works, Beethoven's Promethean identity is likely to remain because it embodies the 
ethical values of a particularly virulent strain of humanism; Beethoven is still employed today to mark the epochal events of human history - from the fall of the Berlin Wall to the atrocities of $9 / 11$. However, the humanism this hero champions has been accused as a cause of the very inhumanity the music is suppose to erase. To offer an alternative is not difficult - there are many works by the composer that do not conform to the Promethean image; but the alternative would be meaningless if it were merely a matter of registering other topics or narratives without grounding the difference in a set of values that challenge the ethical force of the hero. This article sketches the possibility of such an alternative through the ethics of philosophers such as Emmanuel Lévinas and Theodor W. Adorno. It explores an-Other humanism in Beethoven both in the sense of an other Beethoven and a humanism founded on the Other.

Keywords: Ludwig van Beethoven, Theodor W. Adorno, Emmanuel Lévinas, humanism, ethics 